\title{
DISTRIBUIÇÃO E BIODISPONIBILIDADE DO NÍQUEL APLICADO AO SOLO COMO $\mathrm{NiCl}_{2}$ E BIOSSÓLIDO
}

\author{
TADEU CAVALCANTE REIS
}

\author{
Tese apresentada à Escola Superior de Agricultura \\ “Luiz de Queiroz", Universidade de São Paulo, \\ para a obtenção do título de Doutor em Agronomia, \\ Área de Concentração: Solos e Nutrição de Plantas.
}

PIRACICABA

Estado de São Paulo - Brasil

Dezembro - 2002 


\title{
DISTRIBUIÇÃO E BIODISPONIBILIDADE DO NÍQUEL APLICADO AO SOLO COMO $\mathrm{NiCl}_{2}$ E BIOSSÓLIDO
}

\section{TADEU CAVALCANTE REIS}

Engenheiro Agrônomo

Orientador: Prof. Dr. ARNALDO ANTONIO RODELLA

\author{
Tese apresentada à Escola Superior de Agricultura \\ “Luiz de Queiroz”, Universidade de São Paulo, \\ para a obtenção do título de Doutor em Agronomia, \\ Área de Concentração: Solos e Nutrição de Plantas.
}

PIRACICABA

Estado de São Paulo - Brasil

Dezembro - 2002 


\title{
Dados Internacionais de Catalogação na Publicação (CIP) \\ DIVISÃO DE BIBLIOTECA E DOCUMENTAÇÃO - ESALQ/USP
}

\begin{abstract}
Reis, Tadeu Cavalcante
Distribuição e biodisponibilidade do níquel aplicado ao solo como $\mathrm{NiCl}_{2} \mathrm{e}$ biossólido / Tadeu Cavalcante Reis. - - Piracicaba, 2002.

$105 \mathrm{p}$.

Tese (Doutorado) - - Escola Superior de Agricultura "Luiz de Queiroz", 2002.

Bibliografia.
\end{abstract}

1. Alface 2. Analise do solo 3. Equilibrio químico 4. Lodo de esgoto 5. Metal pesado 6. Níquel 7. pH do solo 8. Química do solo l. Título

CDD 631.41

"Permitida a cópia total ou parcial deste documento, desde que citada a fonte - O autor 


\section{À minha esposa CRISTINA, pelo seu incentivo incondicional, compreensão, companheirismo e busca incessante por minha felicidade}




\section{AGRADECIMENTOS}

A Deus, pela vida que me deu, pela saúde que nunca deixou me faltar, pela família que me presenteou e pelas amizades que me proporcionou;

Ao meu orientador, Arnaldo Antonio Rodella pela sua orientação dedicada, pela confiança, pelo apoio, por sua amizade e sobretudo pelo seu exemplo de profissional;

À Professora Maria Emília Mattiazzo-Prezotto, pela orientação no período de agosto de 2000 a outubro de 2001 e apoio constante;

À Coordenação do Curso de P.G. em Solos e Nutrição de Plantas, pela oportunidade;

À CAPES pela bolsa de doutorado concedida durante o período de fevereiro a dezembro de 1999;

À FAPESP, pela bolsas de doutorado, concedida a partir de janeiro de 2000 e pela reserva técnica que viabilizaram este trabalho;

Aos colegas e amigos, Fábio Prata, Adriana Pires, Marcos Gama, Genelício Rocha, Marcelo Alves, Cristiano Andrade, Robson Barizon, Edna Bertoncini, Fabio Valle, Oscarlina Weber, Silvino Guimarães, Marcelino Guedes e tantos outros, pela troca de e experiências e pelos momentos agradáveis que me proporcionaram; 
Ao amigo Pedro Louça e sua família, pela amizade e desprendimento que possibilitaram que a sua casa fosse a referência de família para a comunidade baiana em Piracicaba;

Aos amigos Weliton Almeida, José Fernandes, Carlos Augusto, Carlos Estevão, Manoel Pedro, Leia, Angélica, Elvis, suas respectivas famílias, além de Genelicio, Laércio, Edmilson e Marcelo, por fazerem parte da minha família em Piracicaba;

À colega Ana Paula Packer, pela ajuda nas determinações;

A Josimar Ramos pela ajuda na montagem e condução dos experimentos;

À estagiaria Letícia, pelo auxílio na realização das análises;

Ao corpo docente e funcionários do setor de Química Analítica do Departamento de Ciências Exatas, pela colaboração e amizade que me dedicaram; 


\section{SUMÁRIO}

\begin{tabular}{|c|c|}
\hline & Página \\
\hline & ix \\
\hline SUMMARY . & $\mathrm{xi}$ \\
\hline 1 INTRODUÇÃO ............................ & 1 \\
\hline 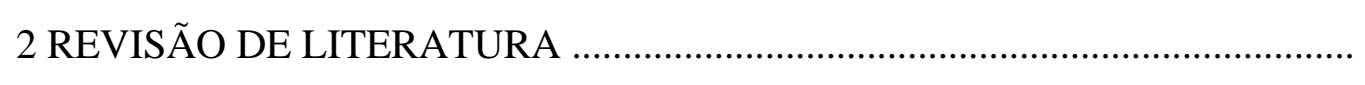 & 4 \\
\hline 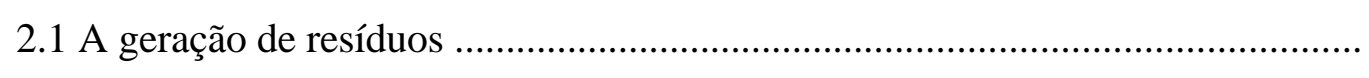 & 4 \\
\hline 2.2 Lodo de esgoto e biossólido .................................. & 4 \\
\hline 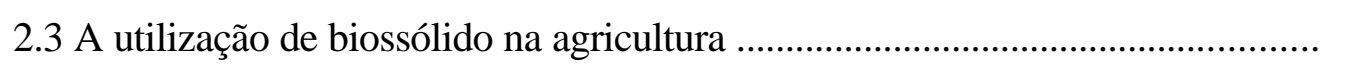 & 5 \\
\hline 2.4 Metais pesados .......................................... & 7 \\
\hline 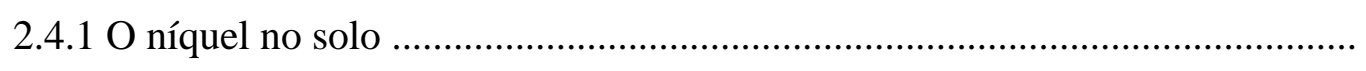 & 11 \\
\hline 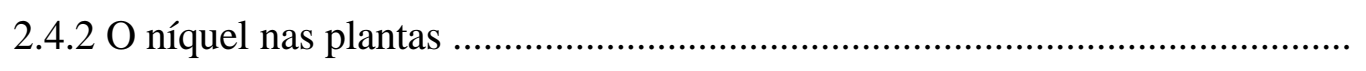 & 13 \\
\hline 2.5 Fracionamento ou extração seqüencial de metais de metais pesados .................. & 14 \\
\hline 2.6 A biodisponibilidade do $\mathrm{Ni}$................................. & 20 \\
\hline 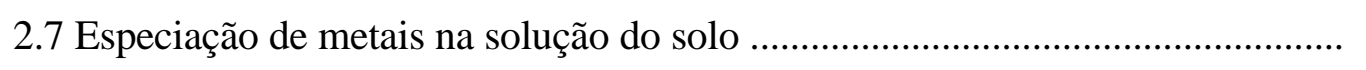 & 21 \\
\hline 2.7.1 Especiação baseada no equilíbrio de Donnan & 22 \\
\hline 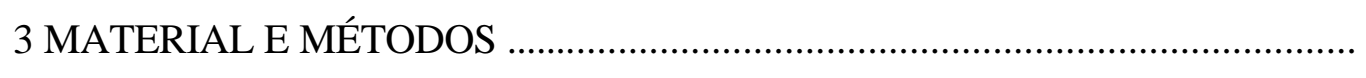 & 25 \\
\hline 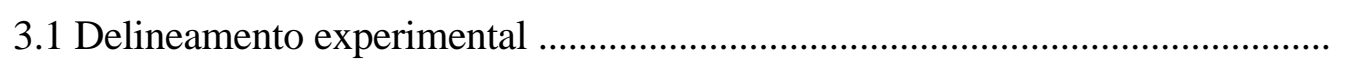 & 25 \\
\hline 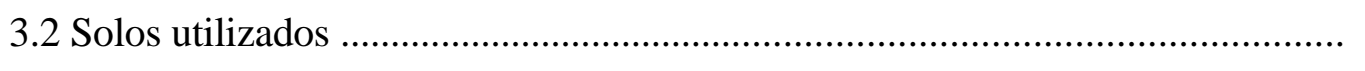 & 25 \\
\hline 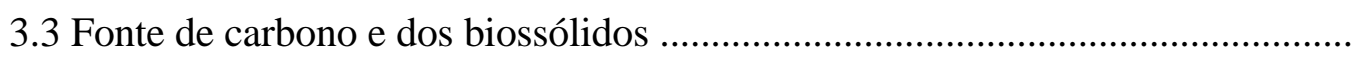 & 27 \\
\hline 3.4 Fonte de níquel ......................................... & 28 \\
\hline 3.5 Agente alcalinizante .................................... & 28 \\
\hline 6 Definição das doses dos bi & 30 \\
\hline
\end{tabular}


3.7 Definição das doses de turfa .......................................................................

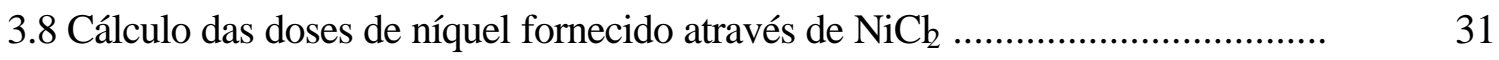

3.9 Montagem e condução dos ensaios em casa de vegetação ................................. 32

3.10 Introdução de plantas nos vasos ................................................................... 33

3.11 Determinação do teor total de níquel ........................................................... 33

3.12 Determinação do teor de níquel no material vegetal ......................................... 34

3.13 Fracionamento químico do níquel ............................................................... 34

3.13.1 Fração trocável + solúvel ........................................................................ 36

3.13.2 Fração ligada aos carbonatos ...................................................................... 36

3.13.3 Fração ligada à matéria orgânica ................................................................ 36

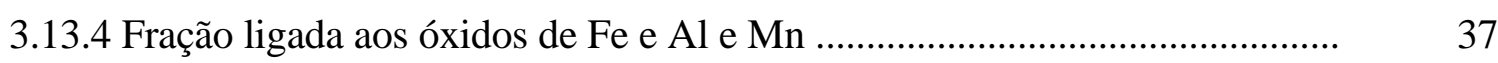

3.13.5 Fração residual ....................................................................................... 37

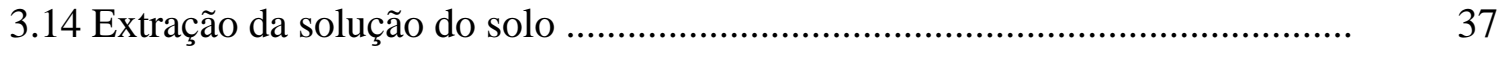

3.15 Medida da condutividade elétrica das soluções ................................................. 38

3.16 Especiação do Ni pelo Equilíbrio de Donnan .................................................... 38

3.17 Determinação analítica dos teores de níquel nos extratos ................................... $\quad 40$

3.18 Análise estatística dos dados ....................................................................... 40

4 RESULTADOS DISCUSSÃO ................................................................... 41

4.1 Teores de carbono orgânico, de níquel total e pH dos solos incubados .............. 41

4.1.1 Resultados dos ensaios com adição de $\mathrm{NiCh}$.................................................... 41

4.1.2 Resultados do ensaio com adição de biossólidos ...............................................

4.2 Resultados do fracionamento do níquel presente nos biossólidos .......................

4.3 Fracionamento químico do Ni dos solos nos ensaios de incubação .................... 50

4.3.1 Eficiência do procedimento ......................................................................... 51

4.3.2 Distribuição do Ni entre as frações ...............................................................

4.3.2.1 Resultados dos ensaios com adição de $\mathrm{NiCh}_{2}$.............................................. 53

4.3.2.2 Resultados dos ensaios com adição biossólidos .......................................... 56

4.3.3 Efeito dos fatores sobre as frações do $\mathrm{Ni}$ no estudo de $\mathrm{NiCh}_{2}$......................... 58

4.4 Níquel no extrato de saturação e especiação pelo Equilíbrio de Donnan ........... 62 


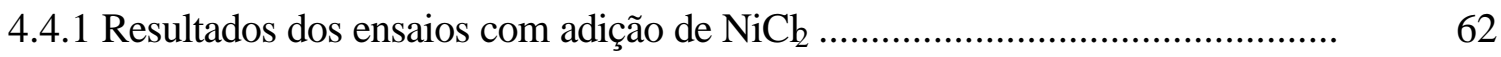

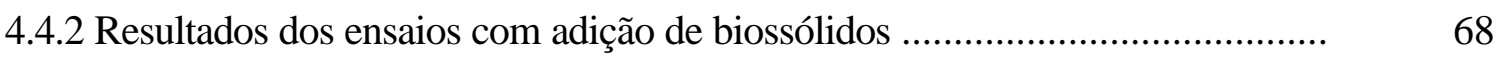

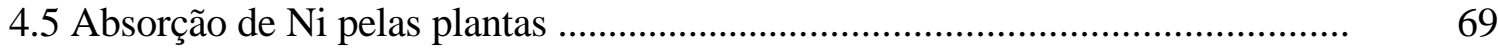

4.5.1 Resultados dos ensaios com adição de $\mathrm{NiCl}$.............................................. 70

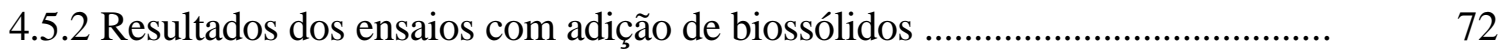

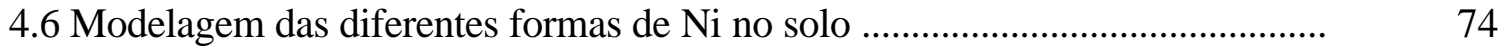

4.6.1 Obtenção das equações de regressão ......................................................... 75

4.6.2 Previsão das formas de $\mathrm{Ni}$ nos solos tratados com biossólidos pelas equações de regressão obtidas nos experimentos com adição de $\mathrm{NiCh}$, calcário e turfa .................................................................................... $\quad 79$

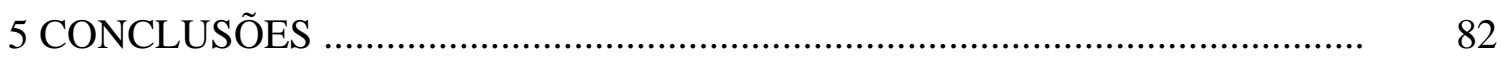

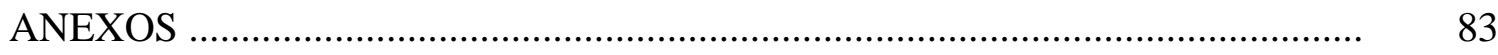

REFERÊNCIAS BIBLIOGRÁFICAS _............................................................ 89 


\title{
DISTRIBUIÇÃO E BIODISPONIBILIDADE DO NÍQUEL APLICADO AO SOLO COMO NiCl2 E BIOSSÓLIDO
}

\author{
Autor: TADEU CAVALCANTE REIS \\ Orientador: Prof. Dr. ARNALDO ANTONIO RODELLA
}

\section{RESUMO}

$\mathrm{O}$ comportamento do $\mathrm{Ni}$ no solo, principalmente quando adicionado através de biossólidos, ainda é pouco conhecido. Este trabalho objetivou avaliar a influência dos teores totais do metal, de matéria orgânica e dos valores de $\mathrm{pH}$ na distribuição daquele elemento no solo e na sua biodisponibilidade. Foram conduzidos três experimentos de incubação em vasos mantidos em casa de vegetação, utilizando $3 \mathrm{~kg}$ de amostras da camada de 0 - 0,20 m de dois solos: ARGISSOLO VERMELHO AMARELO Distrófico (PVAd) e NITOSSOLO VERMELHO Distrófico Latossólico (NVdl). Dois experimentos foram montados em solos diferentes, em esquema fatorial $2 \times 2 \times 3$, nos quais 2 doses de $\mathrm{Ni}\left(21\right.$ e $42 \mathrm{Kg} \mathrm{ha}^{-1}$ ) como $\mathrm{NiCl}$, foram incubadas durante 120 dias, sob dois teores de matéria orgânica e dois valores de $\mathrm{pH}$, obtidos pela adição de turfa e de calcário, respectivamente. Num terceiro experimento fatorial $(2 \times 4)$, os mesmos dois solos foram incubados por 150 dias com a dose de $150 \mathrm{Mg} \mathrm{ha}^{-1}$ de quatro diferentes biossólidos. Posteriormente, cultivou-se alface em todos os vasos por 50 dias Após a incubação, amostras de solo foram analisadas quimicamente, inclusive efetuando-se extrações seqüenciais para determinar a distribuição do $\mathrm{Ni}$ adicionado através de $\mathrm{NiCh}$ e de biossólido. Foram consideradas as frações do metal solúvel + trocável, carbonatos, matéria orgânica, óxidos e residual. Realizou-se também a especiação do Ni baseada no 
equilíbrio de Donnan, no extrato de saturação das amostras, para discriminar a porção do Ni solúvel que se achava na forma de íon livre. O calcário foi o fator que mais afetou o comportamento do metal, reduzindo a concentração na fração trocável e aumentando-a nas frações matéria orgânica e óxidos. A turfa aumentou os teores do metal na fração trocável e os reduziu nas frações óxidos e matéria orgânica. $\mathrm{O} \mathrm{NiCb}$ aumentou o teor de Ni nas três frações citadas. Os teores do metal nas frações de cada solo foram modelados por equações de regressão, em função dos teores de C-orgânico, Ni total e pH do solo. A distribuição do $\mathrm{Ni}$ no solo, quando adicionado através de biossólidos apresentou semelhanças com a distribuição do metal nos próprios biossólidos. Nestes casos, o Ni predominou nas frações mais fortemente retidas, conferindo ao metal comportamento distinto daquele observado pela adição do $\mathrm{NiCl}_{2}$. Tais diferenças puderam ser confirmadas pela ineficiência das equações obtidas nos experimentos com $\mathrm{NiCl}_{2}$, em predizer os teores do metal nas frações dos solos tratados com biossólidos. Na especiação, doses mais elevadas de calcário e turfa resultaram em menores teores de $\mathrm{Ni}$ solúvel e livre, os quais aumentaram com a dose de $\mathrm{NiCl}_{2}$. Concentração de ambas as formas de $\mathrm{Ni}$ se correlacionaram com os teores do metal absorvidos pelas plantas. $\mathrm{Na}$ aplicação de biossólidos ao PVAd, a determinação do Ni livre foi particularmente importante para se prever a biodisponibilidade de Ni para alface. Essencialmente, podese concluir que a extração seqüencial e a especiação em extrato de saturação foram eficientes para demonstrar diferenças do comportamento do níquel quando o metal foi aplicado como $\mathrm{NiCl}_{2}$ e como biossólido. 


\title{
DISTRIBUTION AND BIOAVAILABILITY OF NICKEL APPLIED TO SOIL AS NiCl 2 AND BIOSSÓLID
}

\author{
Autor: TADEU CAVALCANTE REIS \\ Orientador: Prof. Dr. ARNALDO ANTONIO RODELLA
}

\section{SUMMARY}

The role of Nickel in soils under the application of biossolids is still not very well known. The objectives of this study were to investigate the influence of total Nickel and organic carbon content, and soil $\mathrm{pH}$, in the Nickel distribution among soil fractions and the bioavailability of the metal to lettuce. Three incubation pot trials were carried out in greenhouse placing in each one $3 \mathrm{~kg}$ of the $020 \mathrm{~cm}$ layer of soil. Two soils types were considered: Typic Halpludult and Rhodic Kandiudox. In two of the trials, one for each soil type, soil samples were treated with rates of $\mathrm{NiCh}$, lime and peat as a source of organic matter and incubated during 120 days. In the third pot trial the above mentioned soils were incubated with four different types of biossolids during 150 days. Once the incubation period ended soils samples were collected and lettuce was panted in the pots of all three trials. Soils samples were submitted to a sequential extraction procedure which comprised the following fractions: exchangeable plus soluble; carbonate, organic, oxides and residual. Soil saturation extracts were also obtained for the determination of free $\mathrm{Ni}^{+2}$ concentration using the Donnan equilibrium technique. When $\mathrm{NiCb}$, peat, and lime were applied to soils, changes in $\mathrm{pH}$ due to lime caused exchangeable $\mathrm{Ni}$ to decrease and raised $\mathrm{Ni}$ content in organic and oxide fractions. Peat promoted an higher $\mathrm{Ni}$ content in the exchangeable fraction and reduced it in the oxide and organic fraction. I contrast $\mathrm{NiCh}$ raised $\mathrm{Ni}$ content in all of the above motioned fractions. Nickel content 
in all soil fractions were modeled by regression equations using total $\mathrm{Ni}$, organic carbon, and $\mathrm{pH}$ as independent variables. Data for the Ni distribution in soils fractions under biossolids application were similar to results from sequential extraction in the biossolids in terms of percentage. In the biossolids trial $\mathrm{Ni}$ occurred most in residual fraction of soil, which contrasts with results obtained when $\mathrm{Ni}$ was supplied as $\mathrm{NiCb}$. Speciation study showed that higher rates of lime and peat promoted lower levels of soluble and free $\mathrm{Ni}$ in the soil solution. The opposite was detected when $\mathrm{NiCl}$ was applied. Both soluble $\mathrm{Ni}$ and free $\mathrm{Ni}^{+2}$ were well correlated with the $\mathrm{Ni}$ content in lettuce, when the metal salt was supplied as $\mathrm{Ni}$ source. However, free $\mathrm{Ni}^{+2}$ was a better indicator for $\mathrm{Ni}$ bioavailability when bissolids were applied in PVAd. In resume it may be concluded that the sequential extraction procedure and the speciation by means of the Donnan equilibrium approach were useful to express the different behavior of nickel in soil when $\mathrm{NiCl}_{2}$ or bissolids were the source of the metal. 


\section{INTRODUÇÃO}

O comportamento de um elemento no solo é definido em função de sua ocorrência em diferentes compartimentos, tais como: solução do solo, fração ligada a óxidos, à matéria orgânica, entre outros. Em se tratando de metais, principalmente daqueles denominados como metais pesados, o conhecimento das relações de equilíbrio entre as sua concentrações nesses compartimentos é de fundamental importância para avaliar a sua biodisponibilidade.

Os metais pesados normalmente não ocorrem nos solos agrícolas em níveis preocupantes, porém, esta é uma possibilidade que tem sido discutida recentemente, em função do uso continuado de fertilizantes e corretivos e, principalmente, de fontes alternativas de nutrientes as plantas, como biossólidos e resíduos industriais.

Com aumento da densidade populacional nas cidades, uma grande quantidade de águas residuais passou a ser gerada. Apesar de seu destino ser os cursos d'água, o aumento da conscientização ambiental da sociedade, principalmente no que diz respeito à qualidade de água potável, tem tornado esta prática cada vez mais inconcebível. Dessa forma, é cada vez mais comum a presença de estações de tratamento de efluentes líquidos nas cidades, as quais devolvem as rios uma água praticamente livre de matéria orgânica e de organismos patogênicos.

Como resultado do tratamento das águas residuais, gera-se um material orgânico denominado biossólido, o qual tem sido destinado a diversos fins. Dentre estes, a aplicação em áreas agrícolas como fonte de nutrientes e matéria orgânica vem crescendo em importância. Se por um lado a utilização agrícola do biossólido apresenta uma série de vantagens, a presença de metais pesados neste material, como cádmio $(\mathrm{Cd})$, cobre 
$(\mathrm{Cu})$, níquel $(\mathrm{Ni})$, zinco $(\mathrm{Zn})$ e chumbo $(\mathrm{Pb})$, pode ocasionar sérios problemas ambientais.

Quando um elemento químico chega ao solo por meio de um material qualquer, ele passa a interagir com diferentes componentes, participando dos diferentes sistemas de equilíbrio que atuam no solo, como equilíbrios ácido/base, precipitação/dissolução; complexação, oxidação/redução; adsorção/dessorção. A intensidade dos processos é afetada pelos diferentes atributos do solo tais como: $\mathrm{pH}$, teor de matéria orgânica e de óxidos, textura, potencial redox, entre outros.

Informações referentes ao comportamento dos metais pesados adicionados ao solo pela aplicação de biossólido ainda são relativamente escassas, principalmente para o Ni, elemento este que apresenta grande mobilidade no solo e tem ocorrido em elevadas concentrações em alguns biossólidos brasileiros.

Toda e qualquer discussão envolvendo uso de materiais contendo possíveis elementos tóxicos deve ser embasada em resultados de pesquisa, para definir o destino desses elementos no solo e o risco de sua entrada na cadeia alimentar. Analises químicas rotineiras em geral fornecem teores totais de elementos, os quais não se relacionam com biodisponibilidade. Assim é importante buscar ferramentas que permitam interpretar o efeito da ocorrência dos metais dentro de uma perspectiva racional.

É inevitável que se usem recursos diferenciados daqueles adotados nas avaliações rotineiras de fertilidade do solo, ainda que mais trabalhosos e de maior custo, tais como: métodos de extração seqüencial para fracionamento de metal na fase sólida; especiação de formas do elemento em solução, métodos instrumentais de baixo limite detecção, dentre outros.

$\mathrm{O}$ objetivo geral do presente trabalho foi relacionar o comportamento do $\mathrm{Ni}$ adicionado ao solo como sal solúvel e o comportamento do mesmo adicionado através de biossólido.

Como objetivos específicos podem ser enumerados:

- avaliar a distribuição do elemento Ni na solução e na fase sólida de solos com teores de óxidos distintos, variando as condições de $\mathrm{pH}$, teor de matéria orgânica e doses de Ni fornecidas por adição de sal solúvel; 
- avaliar a distribuição do elemento Ni na solução e na fase sólida de solos com teores de óxidos distintos, sob as condições determinadas pela aplicação de diferentes tipos de biossólidos;

- relacionar as informações obtidas pelos procedimentos analíticos empregados com dados de absorção de Ni por uma planta indicadora, a alface. 


\section{REVISÃO DE LITERATURA}

\subsection{A geração de resíduos}

A grande quantidade de esgotos e lixo gerada nos centros urbanos é um dos maiores problemas ambientais a serem enfrentados pela humanidade neste século. $\mathrm{O}$ volume crescente destes materiais vem acelerando o ritmo de degradação dos recursos naturais.

Em 1996, apenas 30\% dos esgotos gerados no Brasil eram coletados, e destes, somente cerca de $8 \%$ recebiam algum tipo de tratamento (Luduvice, 1998). Para se ter idéia da dimensão do problema, cerca de 10 milhões de $\mathrm{m}^{3}$ de esgotos são coletados e despejados diariamente nos cursos d'água sem nenhum tipo de tratamento (Andreoli \& Pegorini, 1998). O problema tende a se agravar nas próximas décadas com a inclusão de milhões de habitantes como usuários das redes de coleta de esgoto.

Esse quadro reforça a observação de que o tratamento dos esgotos é uma prática imprescindível para a preservação dos recursos naturais. Contudo, como resultado deste tratamento, é produzido o lodo de esgoto, cujo destino final é problemático e oneroso, podendo representar cerca de $60 \%$ dos custos de uma ETE (estação de tratamento de esgoto).

\subsection{Lodo de esgoto e biossólido}

O lodo de esgoto se enquadra como resíduo, segundo a definição da Associação Brasileira de Normas Técnicas (ABNT; NBR 10004, 1986): "Resíduos nos estados sólido e semi-sólido, que resultam da comunidade e origem industrial, doméstica, 
hospitalar, comercial, agrícola e de serviços de varrição". Ficam incluídos nesta definição os lodos provenientes de sistemas de tratamento de água, aqueles gerados em equipamentos e instalações de controle de poluição, bem como determinados líquidos cujas particularidades tornem inviável o seu lançamento na rede pública de esgoto ou corpos de água, ou exijam para isso soluções técnicas e economicamente viáveis face a melhor tecnologia disponível.

O termo biossólido foi criado no final da década de 80, ms Estados Unidos, com objetivo de distanciar o lodo adequadamente tratado da imagem do material fecal que o originou. Com esta nova denominação, esperava-se que o potencial agrícola do lodo de esgoto tratado fosse mais considerado que o preconceito envolvido com a sua utilização na agricultura (Luduvice, 1998).

A Agência de Proteção Ambiental dos Estados Unidos (USEPA/ EUA), através de uma regulamentação (Estados Unidos, 1995), define biossólido como um produto sólido orgânico produzido por processos de tratamento dos esgotos municipais e que pode ser reciclado. Por convenção, o termo biossólido foi aceito pela comunidade científica brasileira, para designar o lodo de esgoto doméstico que tenha passado por uma decomposição microbiológica parcial e que seja passível de utilização, sem criar qualquer impacto negativo para o meio.

\subsection{A utilização de biossólido na agricultura}

Dentre os diversos destinos dados aos biossólidos, a aplicação em áreas agrícolas vem crescendo em importância. $\mathrm{O}$ potencial agronômico desses materiais está fundamentado basicamente nos elevados teores de C-orgânico presentes na sua composição. Aumentar o teor de C-orgânico do solo pode significar melhorias nas suas

propriedades físicas, químicas e biológicas. Esses materiais também trazem em sua composição apreciáveis quantidades de nutrientes como nitrogênio e fósforo.

O conhecimento da composição química dos biossólidos é de fundamental importância, pois serve de base para tomadas de decisões como a conveniência de utilizá-los ou não em solos agrícolas e o estabelecimento das taxas de aplicação. 
Segundo Sommers et al. (1976), os fatores que determinam essa composição são: o método de tratamento, a variabilidade sazonal e o tipo e o grau de industrialização da região onde são gerados os esgotos.

De acordo com Kirkham (1982), o poder fertilizante do lodo de esgoto vem sendo estudado nos Estados Unidos dede 1925. Entre os vários trabalhos que relatam os efeitos benéficos do material à produtividade das culturas encontram-se Leslie (1970), Mays et al. (1973), Sabey et al. (1977) e Cripps et al. (1992).

Os estudos com biossólidos no Brasil são tão recentes quanto a preocupação com o tratamento dos esgotos. Dentre os primeiros estudos sobre o potencial do uso agrícola do material podem ser citados os realizados por Santos (1979), Carvalho \& Barral (1981) e Bettiol \& Carvalho (1982).

De modo geral, quando o biossólido é utilizado com a finalidade de fertilização de plantas, os macronutrientes $\mathrm{N}, \mathrm{P}$ e $\mathrm{K}$, exigidos em maior quantidade, necessitam ser complementados com adubação mineral.

Trabalhos com aplicação de biossólido na cultura do sorgo granífero identificaram problemas no fornecimento de $\mathrm{P}$ e deficiência de $\mathrm{K}$ nas plantas fertilizadas com o resíduo. Contudo, verificaram-se melhorias nas condições gerais de fertilidade dos solos como o aumento de $\mathrm{CTC}, \mathrm{SB}, \mathrm{pH}$, teor de $\mathrm{Ca}, \mathrm{Cu}, \mathrm{S}, \mathrm{Zn}$ e matéria orgânica (Cripps \& Matocha, 1991).

Dentre os diversos efeitos da utilização agrícola de biossólidos, a alteração da reação dos solos merece destaque. Esses materiais contribuem com a elevação do $\mathrm{pH}$ dos solos, seja pelas reações de degradação da sua carga orgânica (Epstein et al. 1976; Logan et al. 1983), seja pela alcalinidade intrínseca quando esses são tratados com $\mathrm{CaO}$ $+\mathrm{FeCl}_{3}$ (Barreto, 1995; Basta \& Sloam, 1999; Reis \& Rodella, 2002; Oliveira, 2000). No último caso o referido tratamento é realizado em algumas ETEs com a finalidade de facilitar a desidratação do resíduo, além de reduzir número de organismos patogênicos. Com a elevação do $\mathrm{pH}$ do resíduo ocorre também a redução da disponibilidade dos metais pesados por precipitação.

Embora sejam evidentes benefícios obtidos com a aplicação de biossólidos ao solo, os metais pesados presentes nesses materiais se constituem numa das principais 
preocupações quanto a possíveis contaminações do solo e dos mananciais hídricos. Os biossólidos de diferentes origens apresentam grande variação nos teores de metais como $\mathrm{Cu}, \mathrm{Cd}, \mathrm{Cr}, \mathrm{Ni}, \mathrm{Pb}$, e Zn (Kabata-Pendias \& Pendias, 1984; Kuchenrither \& McMillan, 1990).

Estudando a disponibilidade de metais pesados na cultura da alface em três solos tratados com biossólidos alcalino e ácido, Basta \& Sloam (1999) constataram que os teores de $\mathrm{Cd}$ e $\mathrm{Zn}$ na planta e na solução dos solos tratados com biossólido ácido foram maiores que os obtidos nos tratamentos com biossólido alcalino. Dessa forma, os autores desaconselham o uso de biossólidos ácidos em solos com reação também ácida, por aumentar os riscos de lixiviação e fitodisponibilidade de metais pesados.

Por outro lado, aplicações sucessivas de biossólidos tratados com quantidades exageradas de $\mathrm{CaO}$ e $\mathrm{FeCl}_{3}$ podem ocasionar salinidade, prejudicando o desenvolvimento das plantas por desequilíbrio nutricional e dificuldade de absorção de água e nutrientes (Bertoncini,1997; Anjos, 1999; Oliveira, 2000). Após um mês da

aplicação de $240 \mathrm{Mg} \mathrm{ha}^{-1}$ de biossólido a solos, Epstein et al. (1976) verificaram que o valor da condutividade elétrica dos solos elevou-se de $0,4 \mathrm{mS} \mathrm{cm}^{-1}$ para $5,4 \mathrm{mS} \mathrm{cm} \mathrm{cm}^{-1}$,

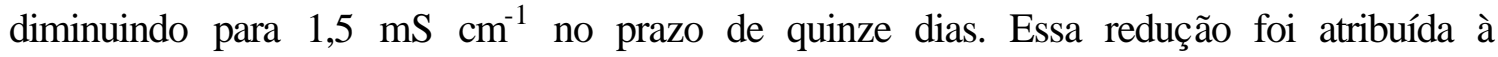
lixiviação de íons.

Algumas ETEs têm procurado reduzir as quantidades de $\mathrm{CaO}+\mathrm{FeO}_{3}$ nos biossólidos ou mesmo substituí-los por polieletrólitos, com o objetivo de melhorar as características do resíduo para fins agrícolas. Além disso, há uma redução dos gastos com transporte devido a redução do volume de material produzido. Contudo, deve-se salientar que o uso de biossólidos não alcalinos em solos ácidos pode potencializar os riscos de contaminação ambiental.

\subsection{Metais pesados}

Os metais pesados podem ter tanto uma origem geoquímica quanto antrópica. Esses elementos são quase sempre constituintes de minerais primários de rochas ígneas e são incorporados na rede cristalina pelo processo de substituição isomórfica de 
elementos como Fe e Al, no momento da cristalização (Pierrisnard, 1996). Enquanto as rochas sedimentares e argilitos podem concentrar grande quantidade de metais, os teores destes nos argilitos são baixos. As principais fontes antrópicas de metais nos solos são o uso de corretivos e fertilizantes, as deposições atmosféricas e o uso de resíduos como o biossólido (Kabata-Pendias \& Pendias, 1984). O conhecimento do comportamento dos metais pesados no solo é de extrema importância para a avaliação do impacto ambiental provocado pela disposição em solos agrícolas, de resíduos contendo esses elementos (Sposito et al., 1982). A extensão deste impacto está relacionada diretamente com a habilidade do solo em reter esses metais (Elliott et al., 1986).

Para predizer o destino dos metais pesados no solo, a longo prazo, é imprescindível o conhecimento das suas principais formas e prováveis transformações no ambiente (Beckett, 1989).

Os metais pesados contidos nos resíduos adicionados aos solos passam por diversas reações, as quais determinam as espécies químicas e físicas difundidas neste ambiente (Essington \& Mattigod, 1991). Tais reações envolvem processos de precipitação/dissolução, adsorção/dessorção, complexação e oxi-redução, nas fases orgânica e inorgânica do solo (Alloway, 1990). A intensidade desses processos é influenciada por atributos dos solos tais como $\mathrm{pH}$, textura e composição mineral (teor e tipos de argilas, teor de óxidos de ferro, de alumínio e de manganês), teor de matéria orgânica, capacidade de troca catiônica (CTC), potencial redox, composição da solução do solo e a temperatura ambiente (Kabata-Pendias \& Pendias, 1984; Alloway, 1990).

No processo de precipitação, um íon metálico reage com outros íons solúveis para formar um produto sólido. A composição da solução, o $\mathrm{pH}$ e o potencial redox do solo são os atributos que mais interferem nesse processo. Os metais pesados podem ser precipitados como hidróxidos, sulfatos, sulfitos, fosfatos e carbonatos, sendo alguns desses precipitados mais resistentes à dissolução do que outros, sob mudanças das condições de solo, como a acidificação. Alguns precipitados, devido à baixa densidade, podem permanecer em suspensão na solução do solo e, desta forma, se movimentar por fluxo de massa (Kabata-Pendias \& Pendias, 1984; Adriano, 1986). 
Os metais pesados podem ser complexados por espécies orgânicas ou inorgânicas conhecidas como ligantes. Entre as orgânicas, as mais comuns são os ácidos fúlvicos e húmicos derivados da matéria orgânica. Metais pesados como $\mathrm{Cu}, \mathrm{Mn}, \mathrm{Ni}, \mathrm{Pb}$ e $\mathrm{Zn}$ apresentam grande afinidade com tais ligantes, possibilitando a redução da disponibilidade desses elementos às plantas, devido a pouca solubilidade dos complexos formados (Adriano, 1986).

A tendência dos cátions metálicos interagirem com ligantes inorgânicos e formarem complexos menos fitodisponíveis pode ser explicada por um sistema de classificação dos íons em ácidos e bases (Pearson, 1963). Os complexos formados em solução ocorrem preferencialmente pelas ligações entre ácidos e bases duros e entre ácidos e bases moles. Desta forma, o $\mathrm{Cd}^{2+}, \mathrm{Cu}^{2+}, \mathrm{Fe}^{2+}, \mathrm{Ni}^{2+}, \mathrm{Pb}^{2+} \mathrm{e} \mathrm{Sr}^{2+}$ são complexados preferencialmente por $\mathrm{Cl}, \mathrm{Br}^{-}, \mathrm{SO}_{3}{ }^{2-}, \mathrm{NH}_{3}$, e $\mathrm{NH}_{2}$, enquanto que $\mathrm{Ba}^{2+}, \mathrm{Cr}^{3+}, \mathrm{Fe}^{3+}, \mathrm{Mn}^{2+}$,

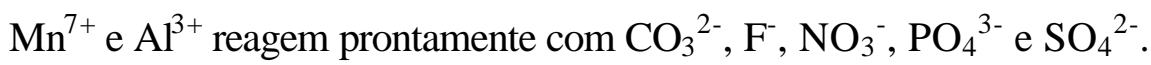

Através de processos de adsorção, os metais pesados nas formas iônicas ou complexados podem ser retidos na superfície de partículas sólidas do solo por forças predominantemente eletrostáticas. Substâncias húmicas, minerais de argila, óxidos e sais como carbonato funcionam como adsorventes de metais pesados. As cargas de superfície são, resultantes de substituições de cátions na estrutura dos cristais, o que ocorre predominantemente em minerais de argila do tipo 2:1, e da desprotonação ou protonação dos grupos $\mathrm{AlOH}, \mathrm{FeOH}, \mathrm{SiOH}$ e $\mathrm{COOH}$ nas superfícies dos materiais, desenvolvendo cargas negativas ou positivas em função do $\mathrm{pH}$ e da força iônica da solução do solo.

Os metais pesados e os minerais do solo também estabelecem ligações mais estáveis que as eletrostáticas através de outros processos como adsorções específicas e co-precipitações.

Por vezes, ocorrem ocorrer interações entre as substâncias húmicas e os óxidos do solo, nas quais os metais servem de ponte para ligação desses materiais. Varadachari \& Chattopadhyay (1997) estudaram a complexação de substâncias húmicas e os óxidos de ferro e alumínio sintetizados, na presença de cátions mono, di e trivalentes. Os autores verificaram que enquanto a ligação dos ácidos húmicos com a goethita foi maior 
na presença de cátions di e trivalentes, com a hematita, foi igual em todas as formas catiônicas testadas. Com a gibbsita, foi reduzida pela presença de qualquer íon. Desta forma, conclui-se que enquanto a goethita e a hematita ligam-se com ácidos húmicos através de cátions, a gibbsita o faz diretamente.

Em experimentos de adsorção de metais à superfície de minerais sintetizados, Egreja Filho (2000) observou uma forte afinidade do Ni com a goethita e a gibbsita, além da ocorrência de difusão do metal no interior do primeiro mineral, devido às falhas ou poros na sua superfície. Esses poros podem ser selados pelas precipitações de $\mathrm{Fe}^{3+}$, reduzindo ainda mais a disponibilidade do metal (Schwertmann et al. 1985). Diante de tal comportamento, é de se esperar que, com o tempo, os metais ligados às formas oxídicas tornem-se cada vez menos disponíveis e que os solos ricos nesses minerais,como os latossolos, sejam bons adsorvedores de metal.

Através de experimentos de adsorção de $\mathrm{Zn}$ em goethita e gibbsita com diferentes idades e graus de cristalinidade, Shuman (1977) verificou que a quantidade do metal retido nos óxidos mal cristalizados foi dez vezes maior que nas formas mais cristalizadas e que a força de ligação do metal ao óxido de alumínio amorfo foi três vezes maior que ao óxido o ferro mal cristalizado.

Outra questão que tem demandado atenção dos pesquisadores se refere à possibilidade de movimento dos metais pesados através do perfil do solo. Embora o solo seja uma barreira natural de proteção dos aquíferos subterrâneos, os fatores que governam a sua capacidade de retenção de metais são bastante complexos, dificultando previsões sobre o comportamento desses elementos.

Apesar da mobilidade dos metais pesados no solo ser apontada como nula ou muito baixa (Baxter et al., 1983; Chang et al., 1984b; Williams et al. 1987), alguns autores têm questionado a persistência da capacidade do solo em reter tais elementos em função do tempo, níveis de contaminação, fatores climáticos e taxas de degradação da carga orgânica dos materiais contaminantes (McBride, 1995; Camobreco et al., 1996 e McBride et al., 1997).

Avaliando a mobilidade de metais pesados num solo que recebeu $240 \mathrm{~kg} \mathrm{ha}^{-1} \mathrm{de}$ biossólido 15 anos antes, McBride et al. (1997) verificaram que, apesar de parte dos 
metais adicionados via resíduo terem sido perdidos da camada de incorporação, os teores dos metais nas camadas mais profundas não demonstraram nenhuma evidência de movimentação desses elementos. De qualquer forma, os autores apontam como possíveis causas das perdas observadas, o caminhamento preferencial de água e de partículas de resíduo e/ou de solo contaminado, através de rachaduras e canais bióticos no solo.

Pelo fato da maior parte dos metais pesados presentes nos solos tratados com biossólidos ocorrer na fase sólida, a identificação das diversas formas químicas desses elementos, através dos procedimentos de fracionamento, é uma importante ferramenta para melhorar o entendimento da mobilidade e da fitodisponibilidade desses elementos no solo.

\subsubsection{O níquel no solo}

O níquel tem como principal origem geoquímica as rochas magmáticas (máficas e ultramáficas) que contêm até $3600 \mathrm{mg} \mathrm{kg}^{-1}$ do elemento. As rochas alcalinas e sedimentares apresentam baixos teores do metal. As emissões atmosféricas variam de 2 a $80 \mathrm{~kg} \mathrm{~km}^{-2} \mathrm{ano}^{-1}$, provenientes de combustão de petróleo. O níquel pode também ser incorporado ao solo através do uso de calcários e de fertilizantes fosfatados, que podem conter até $300 \mathrm{mg} \mathrm{kg}^{-1}$ do metal. Nos biossólidos, sua presença deve-se aos esgotos de indústrias que o utilizam em ligam metálicas, em baterias e compostos eletrônicos, cosméticos e catalisadores (McGrath, 1995).

O conhecimento sobre o comportamento e adsorção do $\mathrm{Ni}$ ainda é relativamente escasso quando comparado a outros metais pesados, sobretudo considerando-se diferentes condições de solo, formas químicas em que o metal é adicionado e da espécie vegetal testada (Sauerbeck \& Hein, 1991). É importante destacar que o Ni é um dos metais que vêm ocorrendo em altas concentrações nos biossólidos brasileiros (Oliveira, 1995).

Estudando as consequências da aplicação de biossólido nas culturas de milho, sorgo e soja, Berti \& Jacobs (1996) identificaram que o Ni é mais problemático do ponto 
de vista ambiental do que, por exemplo, $\mathrm{Cr}, \mathrm{Cu}$ e $\mathrm{Pb}$, pois foi encontrado em maiores proporções nas frações disponíveis às plantas.

De acordo com McGrath (1995), a reação do solo exerce grande influência na retenção do níquel, que se precipita facilmente na superfície dos óxidos. $\mathrm{O}$ elemento encontra-se ligado ao sulfato em solos ácidos e na forma de carbonatos e complexos orgânicos em solos com pH até 8,0.

Mattiazzo-Prezzoto (1994), estudando a influência do pH na disponibilidade dos metais em diversos solos, inclusive do $\mathrm{Ni}$, observou que além do efeito do $\mathrm{pH}$, houve a influência dos teores de carbono orgânico dos solos na disponibilidade dos metais.

Segundo Senesi et al. (1989) e Egreja Filho (2000), o níquel apresenta uma grande afinidade com a fração matéria orgânica, especialmente nos casos em que essa provém de materiais adicionados aos solos. Em solos tratados com biossólidos, Dundley et al. (1987) identificaram o níquel preferencialmente sob a forma de complexos orgânicos.

Utilizando a técnica de espectrometria de absorção de raios-X com estrutura estendida, Eick \& Fendorf (1998) verificaram a retenção diferenciada de $\mathrm{Ni}$ aos minerais, através de dissolução de um mineral e formação de outro, incluindo o metal. Os autores descrevem que o metal foi adsorvido eletrostaticamente numa primeira etapa pela caulinita, provocando um aumento da dissolução do mineral em meio alcalino e a conseqüente liberação de $\mathrm{Al}^{3+}$. Numa etapa posterior, $\mathrm{o} \mathrm{Al}^{3+}$ foi readsorvido à fase sólida juntamente com o níquel, sob a forma de hidróxido misto de Ni e Al.

Apesar de alguns trabalhos com extração sequencial encontrarem o níquel preferencialmente retido na fração residual (McGrath \& Cegarra, 1992; Gomes, 1996; Pierrisnar, 1996), deve-se considerar a possibilidade dos extratores utilizados no procedimento não extraírem com eficiência o metal da fração orgânica e/ou óxidos. Dessa forma, o metal pode permanecer nas amostras até a extração da fração residual, gerando uma informação errônea quanto a sua distribuição nas diversas frações.

O níquel também tem sido encontrado ligado a carbonatos em solos tratados com biossólidos alcalinos (McGrath \& Cegarra, 1992), sendo que as espécies dominantes, 
$\mathrm{NiCO}_{3}$ e $\mathrm{NiHCO}_{3}{ }^{+}$, são susceptíveis à absorção pelas plantas e à lixiviação (Pierrisnar, 1996).

\subsubsection{O níquel nas plantas}

O níquel na forma solúvel é prontamente absorvido pelas raízes e apresenta grande mobilidade na planta. Porém, a quantidade do metal absorvida pelas plantas depende da espécie vegetal (Sauerbeck \& Hein, 1991) e das propriedades do solo, como o pH (Kabata-Pendias \& Pendias, 1984).

Alguns relatos recentes têm considerado a essencialidade do $\mathrm{Ni}$ para plantas superiores (Dordas et al., 2001). Apesar dos mecanismos de sua fitotoxicidade ainda serem pouco conhecidos, sabe-se que altos teores do metal nos tecidos vegetais inibem a fotossíntese e a respiração, sendo que os sintomas de efeito tóxico relacionam-se a lesões nos tecidos, retardamento de crescimento e cloroses. Pode acumular-se nas folhas e grãos e apresenta valor crítico de concentração para vegetais em torno de $11 \mathrm{mg} \mathrm{kg}^{-1}$ de matéria seca. São relatados teores do metal de $0,22-0,34 \mathrm{mg} \mathrm{kg}^{-1}$ em grãos de milho cultivado em solos não contaminados e de 1,6 - 5,2 $\mathrm{mg} \mathrm{kg}^{-1}$ de matéria seca em solos tratados com biossólido (Kabata-Pendias \& Pendias, 1984).

De maneira geral, a toxicidade de níquel se expressa quando a sua concentração na matéria seca for maior que $50 \mathrm{mg} \mathrm{kg}$, com exceção das plantas acumuladoras e hiperacumuladoras (Adriano, 1986).

Aplicando dose de biossólido de $60 \mathrm{Mg} \mathrm{ha}^{-1}$, Wang et al. (1997) relataram que o acúmulo de níquel em plantas de trigo foi maior nas folhas e caules do que nos grãos. Em plantas de feijão, Boareto et al. (1992) encontraram teores de $7,2 \mathrm{mg} \mathrm{kg}^{-1}$ de $\mathrm{Ni}$ nos grãos, para aplicações de doses de biossólido em torno de $10 \mathrm{Mg} \mathrm{ha}^{1}$, contra $0,9 \mathrm{mg} \mathrm{kg}^{-1}$ no tratamento testemunha.

Hooda \& Alloway (1996), avaliando o efeito da calagem em solos tratados com biossólido e cultivados com trigo, cenoura e espinafre, verificaram a redução da disponibilidade de metais pesados com o aumento do $\mathrm{pH}$ e sugeriram a manutenção do 
pH do solo em torno de 7,0 para se evitar a liberação dos metais. Tal condição é de difícil manutenção em solos sob clima tropical.

\subsection{Fracionamento ou extração seqüencial de metais pesados}

Metais adicionados aos solos via resíduos, como biossólidos, podem gerar problemas de poluição das águas subterrâneas e entrar na cadeia alimentar através da absorção pelas plantas. A mobilidade e disponibilidades dos metais nos solos são reguladas pelos processos de degradação dos resíduos e retenção desses metais pelas frações do solo, os quais dependem das características intrínsecas dos resíduos (Pierrisnard, 1996) e dos fatores do solo, tais como: pH, CTC, teores e qualidade de matéria orgânica, argilas e óxidos, potencial redox, temperatura e atividade microbiana (Lindsay, 1979).

A questão das formas que os metais assumem em solos tratados com biossólidos vem sendo abordada desde 1973 (Logan \& Chaney, 1983) e mantém sua importância até os dias atuais, pois são as espécies do metal na fase sólida que controlam, em parte, a concentração na solução do solo. Neste período, muitos pesquisadores têm tentando identificar as formas do metal nos solos e biossólidos, porém estes encontraram uma série de dificuldades, pelo fato de formas distintas dos metais não poderem ser determinadas diretamente (Candelaria \& Chang, 1997).

Apesar da referida impossibilidade, as frações do solo ou biossólidos em que os metais se encontram podem ser identificadas "operacionalmente" por procedimentos de extração sequencial, que utilizam uma série de reagentes com força solubilizante crescente (Lake et al., 1984), o que é útil para avaliar a mobilidade e biodisponibilidade desses metais. O princípio do fracionamento se baseia no fato de elementos cada vez mais imóveis, na fração sólida do solo, poderem ser extraídos por reativos cada vez menos seletivos (Viets, 1962).

Apesar de alguns autores, como Pierrisnard (1996), considerarem que não há

diferença entre os termos fracionamento e especiação, algumas evidencias demonstram que a extração química no fracionamento não representa um método de especiação 
(Lake et al., 1984). Esta é realizada apenas na solução do solo, distinguindo os elementos nas formas precisas e seus estados de oxidação no meio (Amaral Sobrinho, 1993), além dos grupos ligantes (Sposito \& Mattigod,1980).

De acordo com Pierrisnard (1996), a extração sequencial é uma das três formas de efetuar a extração de elementos em amostras de terra. As extrações únicas envolvem uma amostra e um extrator ou mistura de extratores, embora sejam rápidas, econômicas e dêem uma noção dos teores de elementos removidos por determinados reagentes, têm as reações envolvidas influenciadas pela relação sólido:extrator, tempo de extração e mudanças de $\mathrm{pH}$ e ainda estão sujeitas à precipitação de metais durante o processo. As extrações paralelas são realizadas com várias amostras de terra extraídas com diferentes reagentes. Se por um lado não estão sujeitas ao acúmulo de erros da extração anterior, apresentam o inconveniente de necessitar de várias extrações do teor residual. As extrações seqüenciais são as mais usadas para metais e consistem em extrações sucessivas em uma única amostra, utilizando extratores cada vez mais efetivos. Dentre as extrações descritas, esta é a que fornece informações mais precisas sobre a distribuição de metais nas frações da fase sólida, possibilitando inferir sobre a disponibilidade desses elementos.

Diversos fatores podem interferir nos métodos de fracionamento. Dentre esses estão: relação sólido:extrator, sequiência de extração, seletividade dos extratores usados, tempo de contato entre a amostra e o extrator e reabsorção ou precipitação de metais durante o processo de extração (Ross, 1994).

Sposito et al. (1982) e Ross (1994) destacam a importância da escolha de extratores seletivos e da marcha de extração no desenvolvimento dos métodos de fracionamento. A baixa seletividade dos extratores faz com que estes ataquem mais de uma fração ao mesmo tempo, interferindo no equilíbrio das extrações posteriores. Este inconveniente é um dos maiores problemas dos métodos de fracionamento, pois prejudica a eficiência da extração e a confiabilidade dos resultados.

Inúmeros métodos de fracionamento vêm sendo testados desde a década de 70 , sem haver até o momento um procedimento padrão que facilite o confronto de resultados. Tal variação de métodos se deve ao fato do procedimento ser usado para 
materiais com características físico-químicas muito diversas, como tipos diferentes de solos, sedimentos. Verifica-se que na maioria dos trabalhos com fracionamento, o procedimento é apenas uma adaptação de métodos anteriores, desenvolvidos muitas vezes para outras matrizes. Para a correta escolha ou adaptação do método a ser utilizado, é imprescindível o conhecimento das características do resíduo e/ou da matriz de onde serão extraídos os metais.

Stover et al. (1976) realizaram um dos primeiros trabalhos fracionamento de metais em solos tratados com biossólidos. Foram consideradas as seguintes frações e respectivos extratores: trocável $\left(\mathrm{KNO}_{3} 1 \mathrm{~mol} \mathrm{~L}^{-1}\right)$, adsorvida $\left(\mathrm{KF}\right.$ 0,5mol L $\left.{ }^{-1}\right)$, orgânica $\left(\mathrm{NaP}_{2} \mathrm{O}_{7}\right.$ 0,1 mol L $\left.\mathrm{L}^{-1}\right)$, carbonatada (EDTA $\left.0,1 \mathrm{~mol} \mathrm{~L} \mathrm{~L}^{-1}\right)$ e residual $\left(\mathrm{HNO}_{3} 1 \mathrm{~mol} \mathrm{~L}^{-1}\right)$, representada por metais ligados a sulfetos. Os autores concluíram que os metais encontravam-se no solo nas mesmas formas que estavam no resíduo, isto é, a maior parte na fração orgânica e o restante nas formas de sulfatos e carbonatos. Os problemas que podem ser identificados nesse método são a baixa seletividade do KF, que pode extrair metais ligados a óxidos amorfos (Loveland \& Bullock, 1976) e a extração da fração matéria orgânica antes da carbonatada, já que o pirofosfato pode solubilizar metais ligados a esta última (Coffin, 1963).

Tendo em vista as limitações do método proposto por Stover (1976), alguns trabalhos como os de Sposito et al. (1982), Emmerick et al. (1982), Chang et al. (1984a) e Taylor et al. (1995), utilizam-no com modificações baseadas nos estudos realizados por Lund et al (1980). Os dados referentes às frações de metais pesados nas formas trocável, adsorvida, orgânica, carbonatada e residual foram determinadas pela extração sequencial utilizando os seguintes reagentes: $\mathrm{KNO}_{3} 0,5$ mol L $\mathrm{L}^{-1}$; água deionizada, $\mathrm{NaOH}$ 0,5 mol L${ }^{-1}$, EDTA $0,05 \mathrm{~mol} \mathrm{~L}^{-1}$ e $\mathrm{HNO}_{3} 4 \mathrm{~mol} \mathrm{~L}^{-1}$, respectivamente. Candelaria \& Chang (1997) modificaram o referido método na extração da fração residual e obtiveram um digestão mais completa das amostras com a mistura de $\mathrm{HNO}_{3}, \mathrm{HF}$ e $\mathrm{HCl}$ concentrados.

Taylor et al. (1995) fracionaram $\mathrm{Cd}, \mathrm{Cu}, \mathrm{Ni}, \mathrm{Pb}$ e $\mathrm{Zn}$ de um solo argiloso, tratado com biossólido. As análises realizadas nove anos após o início do experimento revelaram que menos de $1 \%$ dos metais adicionados encontravam-se nas frações mais 
disponíveis (solúvel e trocável) e que o parcelamento da dose do resíduo resultou em maiores teores dos metais nas frações estudadas.

A utilização do $\mathrm{NaOH}$ para mobilizar os metais pesados ligados à matéria orgânica apresenta o inconveniente de dissolver outras frações do solo e os metais contidos nestas, como carbonatos (Beckett, 1989), kaolinita (Kampf \& Schwertmann, 1982), gibbsita e silicatos mal cristalizados (Hashimoto \& Jackson, 1960).

Tessier et al. (1979) desenvolveram um método de fracionamento para sedimentos que se tornou o mais citado e usado para vários tipos de matrizes sólidas. $\mathrm{O}$ método utiliza a seguinte sequiência de extratores: $\mathrm{MgCh} \mathrm{pH}$ 7,0 (trocável); $\mathrm{NaCH}_{3} \mathrm{COO}$ $+\mathrm{CH}_{3} \mathrm{COOH} \mathrm{pH}$ 5,0 (carbonatos); $\mathrm{NH}_{2} \mathrm{OH} . \mathrm{HCl}$ em 25\% de $\mathrm{HOAc} \mathrm{pH}$ 2,0 (óxidos de $\mathrm{Fe}$ e $\mathrm{Mn}$ ) $\mathrm{H}_{2} \mathrm{O}_{2}+\mathrm{HNO}_{3} \mathrm{pH}$ 2,0 (matéria orgânica) e $\mathrm{HF}+\mathrm{HClO}_{4}$ (residual). Embora seja usado para solos, o método apresenta alguns inconvenientes. O teor de metais da fração óxidos pode ser superestimado pelo uso do cloridrato de hidroxilamina, uma vez que este também extrai metais da fração matéria orgânica. Além disso, o peróxido de hidrogênio tem se mostrado ineficiente na oxidação da matéria orgânica, fazendo com que os metais dessa fração sejam computados na fração residual.

Para estudar a distribuição de metais pesados em 11 solos da Espanha, Cañadas et al. (1986) realizaram o fracionamento das amostras segundo Tessier et al. (1979). Os autores verificaram que o $\mathrm{Cu}$ e o $\mathrm{Cr}$ se ligam preferencialmente aos óxidos de ferro e manganês, exceto em solos com teores elevados de matéria orgânica. Nesta condição, tais metais foram encontrados associados à fração matéria orgânica. $\mathrm{O} P b \quad$ e o $\mathrm{Cd}$ apareceram nas formas mais disponíveis (trocável e carbonatos).

No Brasil, Amaral Sobrinho et al. (1997) realizaram o fracionamento de metais em amostras de solo incubadas com resíduos de siderúrgicos, utilizando a metodologia de Tessier et al. (1979) sem a extração da fração trocável. Os autores verificaram que todos os metais adicionados passaram para formas menos disponíveis (frações óxido e residual), sendo $\mathrm{Ni}, \mathrm{Cd}$ e $\mathrm{Cu}$ os mais encontrados na fração residual. Os próprios autores identificaram um inconveniente no método: a extração do $\mathrm{Pb}$ da fração óxidos pelo extrator da fração carbonatos. 
Wang et al. (1997) também utilizaram a metodologia de Tessier et al. (1979) para fracionar o $\mathrm{Ni}$ em solos irrigados com efluentes de ETE e em solos sob aplicação de biossólido durante 15, 30 e 40 anos. Os autores verificaram que o metal adicionado ao solo via efluentes foi retido principalmente nas frações óxidos e carbonatada, enquanto que o níquel adicionado por meio de biossólido foi extraído tanto das frações já citadas como da trocável.

Estudando o papel dos óxidos na retenção de metais, Shuman (1977) verificou que as formas mal cristalizadas de óxidos de ferro e alumínio adsorvem dez vezes mais metais que as formas cristalinas, e que a CTC das primeiras é cem vezes maior que das últimas. Desta forma, a inclusão da fração óxidos nos estudos de fracionamento representa um avanço para a melhor compreensão do comportamento dos metais no solo, principalmente naqueles sob condições de clima tropical que normalmente são ricos nesses minerais.

Realizando um estudo de fracionamento de metais em 8 solos dos Estados Unidos, Shuman (1979) extraiu as frações trocável $\left(\mathrm{MgCh}_{2} \mathrm{pH} 7,0\right)$, orgânica $\left(\mathrm{H}_{2} \mathrm{O}_{2}\right)$, óxidos de $\mathrm{Fe}\left(\left(\mathrm{NH}_{4}\right)_{2} \mathrm{C}_{2} \mathrm{O}_{2} \cdot \mathrm{H}_{2} \mathrm{O}+\mathrm{H}_{2} \mathrm{C}_{2} \mathrm{O}_{2} \mathrm{pH} 3\right.$,0) e residual, a qual foi separada em areia, silte e argila $\left(\mathrm{HNO}_{3}+\mathrm{HCl}+\mathrm{HF}\right)$. $\mathrm{O}$ autor destaca a necessidade de resolver a dissolução dos óxidos de manganês pelo $\mathrm{H}_{2} \mathrm{O}_{2}$ e de introduzir outro extrator que dissolva também os óxidos de ferro cristalinos.

Embora o oxalato de amônio acidificado a $\mathrm{pH}$ 3,0 seja eficiente na remoção dos óxidos de ferro amorfos, apresenta pouco efeito sobre os minerais cristalinos (McKeague \& Day, 1966). O ponto crucial para a ação desse extrator é a sua grande sensibilidade à iluminação, o que possibilita um incremento de potencialidade na seguinte ordem: escuro < iluminação difusa < luz solar < luz ultravioleta (UV). Sob esta última condição de iluminação, o oxalato de amônio acidificado a pH 3,0 é tão efetivo na extração de óxidos cristalinos quanto o ditionito (Beckett, 1989). Apesar da sua eficiência, o método não foi bem aceito devido à dificuldade de padronização desta iluminação em cada laboratório (Shuman, 1982).

Shuman (1982) realizou testes com diversos extratores de óxidos dos solos, inclusive o ditionito, utilizado para dissolver estruturas cristalinas. Embora este extrator 
tenha sido o mais eficiente na remoção dos óxidos, se mostrou inviável pela contaminação natural do reagente com $\mathrm{Zn}$ e pela precipitação de metais na forma de sulfatos. Além disso, o ditionito poderia obstruir o queimador dos aparelhos de absorção atômica. Utilizando a premissa de que um bom extrator para óxidos deve ser composto por um agente redutor e um agente complexante para evitar a ocorrência de precipitação, o autor adicionou ácido ascórbico ao oxalato de amônio acidificado a pH 3,0 e obteve um extrator tão eficiente quanto o ditionito na remoção de óxidos de $\mathrm{Fe}, \mathrm{Al}$ e $\mathrm{Mn}$.

Refletindo a importância atribuída aos óxidos na retenção dos metais no solo, Shuman (1985) utilizou um método de fracionamento que dividia os óxidos em três frações e que, segundo o autor, apresenta resultados satisfatórios para vários tipos de solos. O método contempla os teores dos metais ligados às frações trocável $\left(\mathrm{Mg}\left(\mathrm{NO}_{3}\right)_{2}\right.$ pH 7,0); orgânica ( $\mathrm{NaOCl} \mathrm{pH}$ 8,5); óxidos de $\mathrm{Mn}\left(\mathrm{NH}_{2} \mathrm{OH} . \mathrm{HCl} \mathrm{pH}\right.$ 2,0); óxidos de $\mathrm{Fe}$ mal cristalizados $\left(\left(\mathrm{NH}_{4}\right)_{2} \mathrm{C}_{2} \mathrm{O}_{2} \cdot \mathrm{H}_{2} \mathrm{O}+\mathrm{H}_{2} \mathrm{C}_{2} \mathrm{O}_{2} \mathrm{pH}\right.$ 3,0); óxidos de $\mathrm{Fe}$ cristalinos $\left(\left(\mathrm{NH}_{4}\right)_{2} \mathrm{C}_{2} \mathrm{O}_{2} \cdot \mathrm{H}_{2} \mathrm{O}+\mathrm{H}_{2} \mathrm{C}_{2} \mathrm{O}_{2}+\right.$ ácido ascórbico pH 3,0) e residual separada em areia, silte e argila $\left(\mathrm{HNO}_{3}+\mathrm{HCl}+\mathrm{HF}\right)$.

O hipoclorito de sódio é um agente oxidante usado comumente em histologia na limpeza da matéria orgânica não estrutural e diversos trabalhos recomendam sua utilização na estimativa de metais pesados "organicamente ligados" (Iyengar et al., 1981 e Kuo et al., 1983), presumivelmente por destruir moléculas ou grupos orgânicos aos quais os metais estão combinados. Esse extrator, quando usado a $85^{\circ} \mathrm{C}$ e $\mathrm{pH} 8,0$, dissolve por volta de $95 \%$ da matéria orgânica do solo, enquanto que o peróxido de hidrogênio remove de 65 a 80\% (Beckett, 1989). Por outro lado, Miller et al. (1986) assumem que o hipoclorito de sódio mobiliza menos matéria orgânica que o pirofosfato, mas apresenta a vantagem de não dissolver óxidos de Mn.

Mann \& Ritchie (1993) utilizaram um esquema de fracionamento similar ao de Shuman (1985) para estudar o efeito do $\mathrm{pH}$ sobre as formas de Cd nativo e adicionado, em quatro solos australianos. Foram consideradas as frações: solúvel $\left(\mathrm{KCl} 0,005 \mathrm{~mol} \mathrm{~L}^{-1}\right)$; trocável $\left(\mathrm{BaCl}_{2} 0,1 \mathrm{~mol} \mathrm{~L}^{-1}\right)$; ligada à matéria orgânica $(\mathrm{NaOCl}$ $5,3 \%$ a pH 8,5); ligados especificamente aos óxidos $\left(\left(\mathrm{NH}_{4}\right)_{2} \mathrm{C}_{2} \mathrm{O}_{2} \cdot \mathrm{H}_{2} \mathrm{O} 0,2 \mathrm{~mol} \mathrm{~L}^{-1}+\right.$ $\mathrm{H}_{2} \mathrm{C}_{2} \mathrm{O}_{2}$ 0,2 mol L $\mathrm{m}^{-1}$ ácido ascórbico $\left.0,2 \mathrm{~mol} \mathrm{~L}^{-1}, \mathrm{pH} 3,0\right)$ e residual $\left(\mathrm{HNO}_{3} / \mathrm{HClO}_{4} /\right.$ 
$\mathrm{HF}$, concentrados, $+\mathrm{HCl} 6 \mathrm{~mol} \mathrm{~L}^{-1}$ ). Os autores verificaram que tanto a condição de menor valor de $\mathrm{pH}$ como a de menor quantidade de componentes absorventes de $\mathrm{Cd}$ favoreceram a ocorrência do metal em formas mais solúveis.

Ahnstrom \& Parker (1999) se basearam nas revisões de Chao (1988), Beckett (1989) e Shuman (1991) para propor um método de fracionamento com uma ordem de extração mais adequada e com chances mínimas de um extrator retirar metais de atra fração. Esse método diferiu daquele usado por Mann e Ritchie (1993) basicamente por extrair a fração "solúvel + trocável" com $\operatorname{Sr}\left(\mathrm{NO}_{3}\right)_{2} \quad 0,1 \mathrm{~mol} \mathrm{~L} \mathrm{~L}^{-1}$, incluir a extração da fração carbonatos por $\mathrm{NaCH}_{3} \mathrm{COO}+\mathrm{CH}_{3} \mathrm{COOH} \mathrm{pH}$ 5,0 e obter a fração residual através de digestão em forno de microondas coma a mistura de $\mathrm{HNO}_{3}$ e $\mathrm{HCl}$. Pelo fato do $\mathrm{Sr}^{2+}$ ser um íon pouco comum no solo esse método pode também ser usado para elementos como Ca e Mg.

\subsection{A biodisponibilidade do $\mathrm{Ni}$}

Da mesma forma que para outros metais, o potencial fitotóxico de níquel do solo pode ser afetado por uma série de fatores. Diante desta constatação, alguns pesquisadores recomendam o uso do níquel fitodisponível em lugar do níquel total, para fixar limites reguladores de níquel no solo (Sauerbeck \& Hein, 1991). O níquel total do solo apresenta pequena relação com a toxicidade nas plantas, pois não indica a quantia do metal que está disponível para ser absorvido.

Os metais pesados adicionados ao solo são adsorvidos pelos componentes da fase sólida do mesmo, com intensidade e distribuição que dependem das características intrínsecas de cada solo. De acordo com Lee \& Shuman (1996), o resultado desta repartição do metal na fase sólida determina diretamente a sua concentração na solução e consequentemente o seu destino no ambiente do solo.

Os metais pesados podem ocorrer na solução como espécies químicas diferentes: cátions divalentes livres, complexos orgânicos e complexos inorgânicos (Holm et al., 1995). Estas formas também estão diretamente relacionadas às propriedades químicas e 
físicas do solo e podem ser alteradas por mudanças nas condições ambientais (Bigham et al., 1984).

De qualquer forma, diversos autores concordam que a atividade da forma livre na solução é o indicador mais adequado para o comportamento ambiental dos metais, pois determina a biodisponibilidade destes no solo (Bigham et al., 1983; Bigham et al., 1984 e Kabata-Pendias \& Pendias, 1984).

A exemplo da solução do solo, também são encontrados trabalhos em ambientes aquáticos que confirmam a importância da especiação dos metais no prognóstico sua biodisponibilidade. Porta \& Ronco (1993) isolaram ácidos fúlvicos de água de rio e mostraram que a toxicidade do $\mathrm{Cu}$ a um organismo aquático (Brachionus calyciflurus) podia ser prevista a partir de parâmetros relativos à formação de complexos entre o $\mathrm{Cu}$ e os ácidos fúlvicos. Da mesma forma, Kin et al. (1999) concluiram que a toxicidade do íon $\mathrm{Cu}^{2+}$ a um organismo teste (Cerodaphania dúbia) estava mais relacionada à concentração do $\mathrm{Cu}$ livre, ou atividade do íon $\mathrm{Cu}^{2+}$, do que à concentração de $\mathrm{Cu}$ total.

A atividade de um íon metálico de interesse na solução do solo depende, principalmente da sua tendência para formar complexos com espécies orgânicas ou inorgânicas denominadas ligantes. Esta tendência pode ser expressa de forma quantitativa pela constante de estabilidade de cada complexo.

\subsection{Especiação de metais na solução do solo}

Vários métodos para especiação direta de metais na solução do solo não são satisfatórios, pois podem perturbar o equilibro da solução de amostra de tal forma que o metal livre determinado resulte da soma do metal não complexado com algumas frações do metal complexado que dissociou em resposta à medida (Wu et al., 2000).

Uma alternativa bastante utilizada é a estimativa da concentração das espécies dos metais através de cálculos de equilíbrio químico implementados por programas de computador. Estes programas são modelos de especiação iônica que se baseiam nas concentrações totais dos principais elementos presentes na solução do solo e nos valores 
das constantes de estabilidade dos complexos fornecidos pela literatura (Sposito \& Mattigod, 1980).

Um dos pioneiros foi o programa REDEQL (Morel \& Morgan, 1972) que calculava a especiação e a distribuição de fases pelo método de interação de NewtonRaphson. Modificações e melhorias desse método deram origem a outros programas como os seguintes: REDEQL2 (McDuff \& Morel, 1973); MINEQL (Westall et al., 1976); MICROQL (Westall, 1979); GEOCHEM (Sposito \& Mattigod, 1980); SOILCHEM (Sposito \& Coves, 1988); MINTEQ (Felmy, et al., 1984); MINTEQ A2 (Allison et al., 1991).

O programa MINTEQ A2 é um dos modelos de equilíbrio geoquímico para sistemas aquosos diluídos mais utilizados. Ele prediz a composição desses sistemas com base nos resultados de análises químicas da amostra a ser modelada. Esse programa inclui um ligante orgânico composto, denominado DOM, para representar a matéria orgânica natural dissolvida. O modelo considera a matéria orgânica como um material complexo, constituído por um conjunto de sítios monopróticos. Foi tomada como base a matéria orgânica dissolvida, extraída do Rio Suwanee, EUA (Allison et al., 1991).

A limitação básica dos modelos de especiação é que a utilização desses depende da validade das constantes de estabilidade inseridas nos seus bancos de dados. Além de

faltar informação sobre valores confiáveis de constantes para complexos entre metais e substâncias húmicas, as reações de complexação entre estes ainda são pouco compreendidas. A estequiometria 1:1 é tradicionalmente assumida devido à dificuldade em se determinar tal proporção com ligantes que contém uma mistura tão complexa de sítios de ligação.

\subsubsection{Especiação baseada no Equilíbrio de Donnan.}

De acordo com Babcock (1963), a teoria de sistemas de membranas de Donnan foi desenvolvida por F. G. Donnan em 1911 e generalizada por Donnan e Guggenheim em 1932. Mais recentemente, aplicou-se a teoria de Donnan para enriquecimento de uma solução receptora em um determinado íon proveniente de uma solução substrato. Neste 
caso, a força iônica da solução receptora deve ser superior a da solução substrato. Cox \& Cheng (1978) estudaram o enriquecimento em ânions de ácidos fracos, por meio do equilíbrio de Donnan, observando a influência do pH da amostra e da solução receptora. Separações de misturas de cátions empregando o mesmo princípio foram efetuadas por Cox \& Brajter (1981) num processo onde uma membrana foi empregada para separar uma amostra de força iônica relativamente baixa de um eletrólito receptor.

Trabalhando com membrana de troca catiônica, Helmke e colaboradores aplicaram o equilíbrio de Donnan para determinar a atividade de cátions metálicos hidratados lvres na solução do solo (Lampert, 1982; Fitch \& Helmke, 1989; Helmke et al., 1997 e Salam \& Helmke, 1998).

O procedimento é uma modificação da diálise de Donnan em membrana, estudada por Cox e colaboradores, como citado anteriormente. No caso em questão, contudo, uma solução aquosa de amostra (solução doadora), em geral o extrato de saturação, é equilibrada com uma solução receptora de igual força iônica, através de uma membrana de troca catiônica. A igualdade de força iônica é exigida porque não se deseja enriquecimento em uma espécie, mas apenas a equalização da concentração em formas catiônicas livres nas duas soluções postas em contato através da membrana.

Após o equilíbrio ter sido atingido, a solução receptora é analisada por uma técnica analítica conveniente e a concentração de metal determinada equivale à concentração da forma catiônica livre do metal na solução de amostra.

Dentre as vantagens atribuídas a essa técnica destaca-se a mínima perturbação dos equilíbrios naturais que ocorrem na solução de amostra durante as medições. Isso é conseguido empregando-se um volume mínimo de solução receptora em relação ao volume da solução doadora, de modo que uma quantidade muito pequena de metal é suficiente para a equalização das concentrações das formas livres entre as duas soluções posta em equilíbrio.

Empregando técnicas como a espectrometria de absorção atômica com atomização eletrotérmica (forno de grafite) ou espectrometria de emissão atômica com fonte de plasma induzido para a determinação de metais, atinge-se sensibilidade para detectar a atividade dos mesmos a nível nano e micromolar. Essas características 
possibilitam que o procedimento supere outras técnicas como a potenciomentria (eletrodos seletivos) e voltametria de redissolução anódica na determinação da atividade de metais em solução (Helmke, 1999).

Utilizando a técnica do Equilíbrio de Donnan, Temminghoff et al. (2000) determinaram a concentração de cobre livre na presença de ácidos húmicos extraídos de material vegetal depositado em solos de floresta. Comparando os valores determinados experimentalmente com valores calculados por modelo de especiação, os autores observaram que estes apresentavam boa concordância e que 0,1 a $12 \%$ do cobre estava sob a forma de cobre livre. Tal variação foi atribuída às alterações dos valores de $\mathrm{pH}$ e de concentração total do metal.

Smolders et al. (1999), determinando a atividade de metais pela técnica do Equilíbrio de Donnan, observaram em experimento de vasos com soja que quando o $\mathrm{pH}$ $\mathrm{CaCl}_{2}$ do solo variou de 4,5 a 6,2, a atividade do cádmio na solução do solo decresceu 10 vezes, enquanto o teor do elemento em plântulas de soja decresceu apenas 3 vezes. Concluíram que isso explicava o fato de experimentos de campo mostraram baixa eficiência da calagem em reduzir o nível de cádmio em plantas, embora seja uma operação em geral recomendada para reduzir a mobilidade de elementos contaminantes no solo,

Wu et al. (2000) também utilizaram a técnica de Equilíbrio de Donnan para determina as atividades de cádmio, cobre, chumbo e zinco em 10 solos sob contaminação industrial por metais. Os autores concluíram que ao contrário da matéria orgânica, o pH e a concentração total do metal foram fatores preponderantes na definição da atividade dos cátions estudados na solução. 


\section{MATERIAL E MÉTODOS}

O presente estudo compreendeu 3 experimentos conduzidos simultaneamente, em vasos sob condições de casa de vegetação, no setor de Química do Departamento de Ciências Exatas da Escola Superior de Agricultura "Luiz de Queiroz", ESALQ/USP, em Piracicaba - SP. Dois dos experimentos, realizados em tipos de solos diferentes, constaram da aplicação de Ni através de um sal solúvel, além de um agente alcalinizante e de uma fonte de matéria orgânica, com o objetivo de causar variações nos atributos dos solos comparáveis àquelas provocadas pela aplicação de diferentes tipos de biossólidos. Para possibilitar essa comparação foi conduzido um terceiro experimento, incluindo os dois solos estudados nos experimentos anteriores, nos quais foram aplicados quatro diferentes biossólidos.

Esses experimentos serviram de base para estudos de fracionamento do níquel na fase sólida, especiação em solução aquosa e biodisponibilidade, conforme será comentado a seguir.

\subsection{Delineamento experimental}

Os experimentos com adição de $\mathrm{NiCh}_{2}$ diferiram entre si apenas no que se refere ao tipo de solo utilizado e foram conduzidos num delineamento inteiramente casualizado, em esquema fatorial 3×2×2 (3 doses de calcário, 2 doses de Ni e 2 doses de matéria orgânica). $\mathrm{O}$ experimento com adição de biossólidos, também foi montado num delineamento inteiramente casualizado, em esquema fatorial 4x2 (4 biossólidos e 2 solos). Cada tratamento foi estudado em 3 repetições. 


\subsection{Solos utilizados}

Os solos utilizados no experimento foram escolhidos para se obter uma condição diferenciada em relação aos teores de óxidos, visto que estes componentes se mostraram importantes na retenção dos metais no solo (Shuman, 1977). Desta forma, amostras de dois solos classificados como ARGISSOLO VERMELHO AMARElO Distrófico (PVAd) e Nitossolo Vermelho Distrófico Latossólico (NVdl) foram coletadas em áreas produtoras de culturas anuais do Município de Piracicaba - SP, na camada de 0 - $20 \mathrm{~cm}$.

Depois de secas ao ar e passadas em peneira com abertura de malha de $2 \mathrm{~mm}$, as amostras de solo foram caracterizadas quimicamente (Raij \& Quaggio, 1983); granulometricamente (Camargo et al.,1986) e submetidas à analise mineralógica qualitativa por difração de raio $\mathrm{X}$. Os teores de óxidos foram determinados por ataque sulfúrico, de acordo com metodologia descrita em Embrapa (1997). Na Tabela 1 são apresentadas as principais características químicas e na Tabela 2, as principais características físicas e mineralógicas das amostras desses solos.

Tabela 1. Atributos químicos das amostras de solo utilizadas no experimento.

\begin{tabular}{|c|c|c|c|c|c|c|c|c|c|c|c|c|c|}
\hline \multirow[t]{2}{*}{ Solo } & \multicolumn{2}{|c|}{$\mathrm{pH}$} & \multirow{2}{*}{$\begin{array}{l}\text { M.O } \\
\mathrm{g} \mathrm{kg}^{-1}\end{array}$} & \multirow{2}{*}{$\begin{array}{c}P \\
\mathrm{mg} \mathrm{kg}^{-1}\end{array}$} & \multirow[t]{2}{*}{$\mathrm{K}$} & \multirow[t]{2}{*}{$\mathrm{Ca}$} & \multirow{2}{*}{$\begin{array}{c}\mathrm{Mg} \\
\ldots \ldots . . \mathrm{n}\end{array}$} & \multirow{2}{*}{$\begin{array}{c}\mathrm{Al} \\
\mathrm{mol}_{\mathrm{c}}\end{array}$} & \multirow{2}{*}{$\mathrm{H}+\mathrm{Al}$} & \multirow[t]{2}{*}{$S$} & \multirow{2}{*}{$\begin{array}{c}\text { СТC } \\
\ldots 4 . .\end{array}$} & \multirow{2}{*}{\multicolumn{2}{|c|}{$\begin{array}{l}\mathrm{V} \\
\ldots \ldots \ldots \ldots \ldots\end{array}$}} \\
\hline & $\mathrm{CaCl}_{2}$ & $\mathrm{H}_{2} \mathrm{O}$ & & & & & & & & & & & \\
\hline PVAd & 3,7 & 4,6 & 18,0 & 8,0 & 1,7 & 10,0 & 6,0 & 5,0 & 38,0 & 17,7 & 55,7 & 31,8 & 22,0 \\
\hline $\mathrm{NVdl}$ & 4,5 & 5,3 & 27,0 & 10,0 & 3,3 & 30,0 & 22,0 & 2,0 & 47,0 & 55,3 & 102,3 & 54,1 & 3,5 \\
\hline
\end{tabular}

Tabela 2. Atributos granulométricos e mineralógicos das amostras de solo.

\begin{tabular}{|c|c|c|c|c|c|c|c|c|c|c|c|}
\hline \multirow[t]{2}{*}{ Solo } & \multicolumn{3}{|c|}{ Granulometria } & \multicolumn{4}{|c|}{ Óxidos } & \multicolumn{2}{|r|}{ Densidade } & \multicolumn{2}{|c|}{ Minerais presentes } \\
\hline & A reia & $\begin{array}{l}\text { Silte } \\
. \mathrm{g} \mathrm{kg}\end{array}$ & $\begin{array}{l}\text { Arg ila } \\
{ }^{1} \ldots \ldots . . . .\end{array}$ & $\mathrm{Al}_{2} \mathrm{O}_{3}$ & $\begin{array}{r}\mathrm{Fe}_{2} \mathrm{O}_{3} \\
\ldots \ldots \ldots q\end{array}$ & $\begin{array}{l}\mathrm{SiO}_{2} \\
\mathrm{~kg}^{-1} \ldots\end{array}$ & $\mathrm{TiO}$ & $\mathrm{MnO}$ & $\mathrm{g} \mathrm{cm}^{-3}$ & Argila & Silte \\
\hline PVAd & 740 & 60 & 200 & 56 & 25 & 66 & 8,5 & 0,2 & 1,30 & $\begin{array}{l}\text { Clorita, kaolinita, } \\
\text { Gibsita e Mica }\end{array}$ & $\begin{array}{c}\text { Clorita, kaolinita, } \\
\text { Gibsita e Mica }\end{array}$ \\
\hline \multirow[t]{2}{*}{ NVdl } & 370 & 100 & 530 & 152 & 79 & 147 & 14,6 & 0,5 & 1,17 & Pirofilita, Quartzo e & Pirofilita, Quartzo \\
\hline & & & & & & & & & & Anortita & e Anortita \\
\hline
\end{tabular}




\subsection{Fonte de carbono e biossólidos}

A turfa foi selecionada como fonte de carbono orgânico por se tratar de um material já estabilizado, condição mais próxima a dos biossólidos que a dos estercos de animais, por exemplo. Depois de seca, a turfa foi passada em peneira com abertura de malha de $2 \mathrm{~mm}$ e incubada com um agente alcalinizante, para neutralizar sua acidez natural e evitar que os tratamentos que recebessem o material como fonte de carbono orgânico tivessem o seu $\mathrm{pH}$ reduzido. Para essa finalidade utilizou-se calcário com $30,5 \%$ de $\mathrm{CaO}$ e $17,6 \%$ de $\mathrm{MgO}$, submetido a calcinação em mufla a $400^{\circ} \mathrm{C}$ durante 8 horas. Para determinar a dose do material calcinado a ser aplicada, testes de laboratório foram efetuados em amostra de $100 \mathrm{~g}$ de turfa foi umedecida com $300 \mathrm{~mL}$ de água destilada e submetida a medidas de $\mathrm{pH}$ após adição de quantidades crescentes daquele material. A dose de $5 \mathrm{~g} \mathrm{~kg}^{-1}$, necessária para estabilizar do $\mathrm{pH}$ da mistura em torno de 7,0, foi aplicada a toda turfa utilizada nos ensaios.

A seleção dos biossólidos levou em consideração as diferenças entre os processos geradores dos resíduos. Basicamente, biossólidos produzidos com adição de cal apresentam reação alcalina, ao contrário que aqueles que não são. Essa variabilidade está evidenciada por alguns dos atributos químicos destes materiais (Tabela 3).

As amostras de biossólidos selecionadas foram provenientes das seguintes Estações de Tratamento de Esgotos (ETEs): ETE SABESP de Franca; ETE gerenciada pela Companhia de Saneamento de Jundiaí; ETE SABESP de Barueri e ETE SABESP de Suzano, todas localizadas no Estado de São Paulo.

Enquanto o biossólido de Franca sofreu condicionamento químico através da adição de polieletrólitos para facilitar a sua desidratação, aqueles provenientes de Barueri e Suzano foram condicionados através da adição de cloreto férrico e cal hidratada. O biossólido de Jundiaí não recebeu nenhum tipo de condicionamento químico, pois a sua secagem foi feita em leitos de areia.

$\mathrm{Na}$ caracterização química dos materiais orgânicos, o C-oxidável foi determinado pelo método Walkey-Black, sem aquecimento externo, e o $\mathrm{N}$-total pelo método de Kjeldahl. Para a determinação dos metais pesados e macronutrientes, realizou-se a 
digestão nitrico-perclórica, com aquecimento em bloco digestor. Os teores totais dos metais foram determinados por espectrometria de absorção atômica, K por fotometria emissão por indução de chama e P por espectrofotometria. As metodologias utilizadas são descritas por Eaton et al. (1995).

Tabela 3. Atributos químicos da fonte de carbono e dos biossólidos.

\begin{tabular}{ccccccccccc}
\hline Materiais & $\mathrm{pH}\left(\mathrm{H}_{2} \mathrm{O}\right)$ & $\mathrm{C}$ org. & $\mathrm{N}$ total & $\mathrm{P}$ & $\mathrm{K}$ & $\mathrm{Ca}$ & $\mathrm{Mg}$ & $\mathrm{Cu}$ & $\mathrm{Zn}$ & $\mathrm{Ni}$ \\
\hline \multirow{2}{*}{ Biossólido ETE Susano } & 9,8 & 218,4 & 20,54 & 9,86 & 1,05 & 135,5 & 2,21 & 938 & 3045 & 206 \\
Biossólido ETE Barueri & 12,4 & 139,2 & 16,33 & 5,63 & 0,67 & 117,8 & 1,72 & 316 & 1016 & 152 \\
Biossólido ETE Jundiaí & 6,8 & 266,0 & 22,32 & 4,59 & 2,46 & 8,98 & 1,86 & 206 & 656 & 64 \\
Biossólido ETE Franca & 5,7 & 338,5 & 40,93 & 9,57 & 1,03 & 4,96 & 2,33 & 241 & 1237 & 67 \\
Turfa & 4,6 & 427,4 & 12,53 & 0,20 & 0,60 & 2,32 & 1,36 & 18 & 27 & $15 \ldots \ldots \mathrm{g} \mathrm{kg}^{-1} \ldots \ldots \ldots \ldots \ldots \ldots \ldots \ldots \ldots \ldots$ \\
\hline
\end{tabular}

\subsection{Fonte de Níquel}

Para fornecer o elemento níquel na forma solúvel foi usado o sal cloreto de níquel hexahidratado, $\mathrm{NiCh}_{2} \cdot 6 \mathrm{H}_{2} \mathrm{O}$, produzido pela Carlo Erba, com grau de pureza de $99 \%$.

\subsection{Agente alcalinizante}

A variação dos valores de $\mathrm{pH}$ dos solos foi conseguida através da adição doses de calcário com 30,5\% de $\mathrm{CaO}$ e $17,6 \%$ de $\mathrm{MgO}$ e poder de neutralização de $92,7 \%$. A amostra de calcário utilizada era isenta de contaminação por Ni.

As doses de calcário foram calculadas de modo que resultassem em 3 diferentes níveis de pH: o original do solo, o correspondente a uma saturação por bases de $60 \%$ e um valor intermediário entre os dois últimos. 
Para isso, realizou-se um ensaio preliminar de incubação dos solos com doses do calcário, o que permitiu a construção da curva de neutralização destes. Foram incubadas amostras dos dois solos de 0,5 $\mathrm{kg}$, com as doses de calcário $0,1,2,3,4 \mathrm{e} 5 \mathrm{~g} \mathrm{~kg}^{-1}$.

Após 60 dias de incubação, foram determinados os valores de $\mathrm{pH}$ e os teores de $\mathrm{Ca}, \mathrm{Mg}, \mathrm{K}, \mathrm{Al}$ e $\mathrm{Al}+\mathrm{H}$. Com base nestes resultados pôde-se construir os gráficos de Dose de calcário $\boldsymbol{x}$ porcentagem de saturação por bases - V\% (Figura 1) e de pH $\left(\mathrm{H}_{2} \mathrm{O}\right) \quad \boldsymbol{x}$ dose de calcário (Figura 2). Desta forma, foram encontradas as doses de calcário para elevar o valor de V \% de cada solo para $60 \%$ e os respectivos valores de $\mathrm{pH}$.
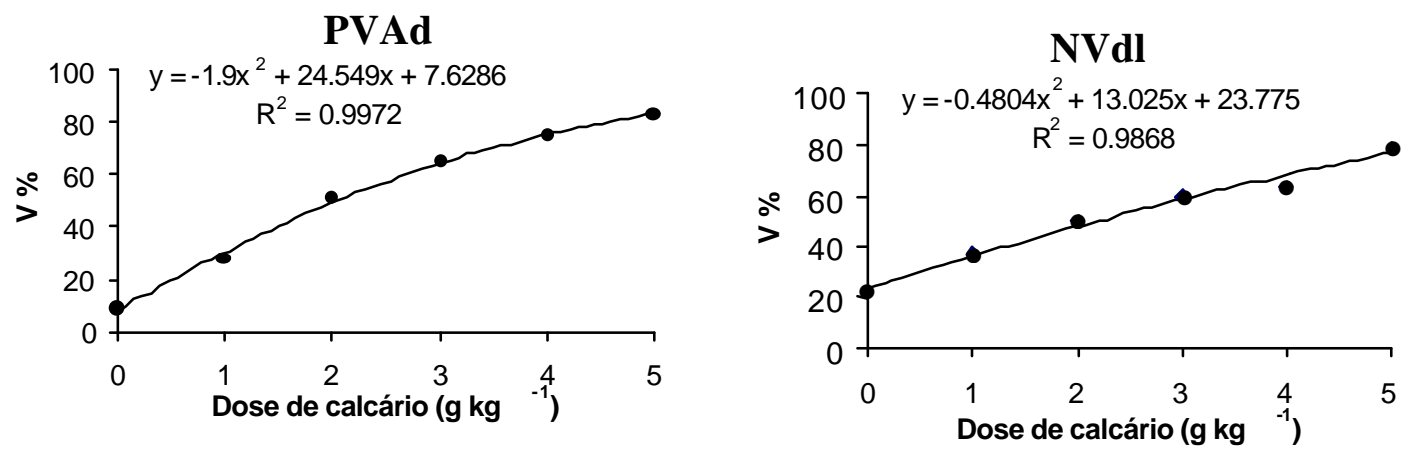

Figura 1 - Variação da porcentagem de saturação por bases em função da aplicação de calcário aos solos PVAd e NVdl.

Utilizando as equações de regressão para cada solo, obteve-se doses de calcário correspondentes a 2,87 e 3,29 $\mathrm{g} \mathrm{kg}^{-1}$ para as amostras dos solos PVAd e NVdl, respectivamente. De posse dessas doses de calcário estimou-se o $\mathrm{pH}$ dos solos corrigidos, através das equações de regressão encontradas na Figura 2. Ambos os valores ficaram próximos à neutralidade, sendo estes 7,09 e 6,93 para os solos PVAd e NVdl, respectivamente.

Para encontrar a dose de calcário que resultasse num valor de $\mathrm{pH}$ intermediário entre o original de cada solo e o alcançado pela maior dose, utilizaram-se os valores de pH 5,8 e 6,1, resultando nas doses de 0,64 e $0,97 \mathrm{~g} \mathrm{~kg}^{-1}$, para os solos PVAd e NVdl, respectivamente. 

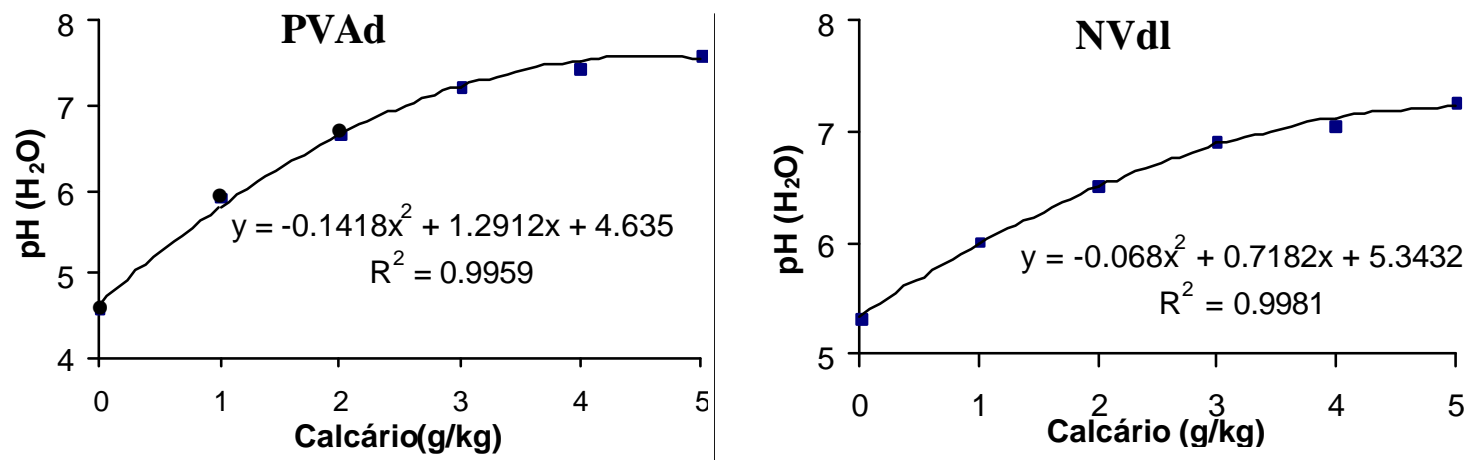

Figura 2 - Variação de pH dos solos em função da aplicação de calcário aos solos PVAd e NVdl.

\subsection{Definição das doses dos biossólidos}

Adotou-se o critério de aplicar $150 \mathrm{Mg} \mathrm{ha}^{-1}$ de todos os diferentes biossólidos, por esta ser uma dose representativa para muitos dos materiais orgânicos aplicados ao solo, além de fornecer quantidades de $\mathrm{Ni}$ comparáveis àquelas dos experimentos adição $\mathrm{NiCl}_{2}$. Para efeito de cálculo das doses dos materiais, considerou-se a incorporação até $10 \mathrm{~cm}$ de profundidade a as respectivas densidades dos solos, resultando nas doses 115,4 $\mathrm{g} \mathrm{kg}^{-1}$ (PVAd) e 128,2 $\mathrm{g} \mathrm{kg}^{-1}$ (NVdl). Na Tabela 4 encontram-se as quantidades adicionadas dos elementos de maior interesse.

Tabela 4. Quantidades dos elementos de maior interesse adicionadas via biossólidos.

\begin{tabular}{|c|c|c|c|c|c|c|c|c|c|c|c|c|c|c|}
\hline \multirow[t]{2}{*}{ Biossólido } & \multicolumn{2}{|c|}{ C orgânico } & \multicolumn{2}{|c|}{$\mathrm{N}$ total } & \multicolumn{2}{|c|}{$\mathrm{P}$} & \multicolumn{2}{|c|}{$\mathrm{K}$} & \multicolumn{2}{|c|}{$\mathrm{Ca}$} & \multicolumn{2}{|c|}{$\mathrm{Mg}$} & \multicolumn{2}{|c|}{$\mathrm{Ni}$} \\
\hline & PVAd & Vdl & PVAd & $\mathrm{NVdl}$ & Ad & NVdl & VAd & NVdl & VAd & NVdl & PVAd & NVdl & PVAd & NVdl \\
\hline & & & & & & & & & & & & & $\mathrm{mg}$ & $\mathrm{kg}^{-1}$ \\
\hline ETE Franca & 39,05 & 43,39 & 4,72 & 5,25 & 1,10 & 1,23 & 0,12 & & 1,73 & 1,92 & 0,27 & 0,3 & 7,73 & 8,59 \\
\hline ETE Jundiaí & 30,69 & 34,10 & 2,58 & 2,86 & 0,53 & 0,59 & 0,28 & 0,32 & 1,04 & 1,15 & 0,21 & 0,2 & 7,38 & 8,21 \\
\hline ETE Banueri & 16,06 & 17,85 & 1,88 & 2,09 & 0,65 & 0,72 & 0,08 & 0,09 & 13,6 & 15,10 & 0,20 & 0,2 & 17,54 & 19,49 \\
\hline ETE Suzano & 25,20 & 28,00 & 2,37 & 2,63 & 1,14 & 1,26 & 0,12 & 0,13 & 15,63 & 17,37 & 0,25 & 0,3 & 23,77 & 26,41 \\
\hline
\end{tabular}




\subsection{Definição das doses de turfa}

A dose de turfa foi calculada de forma a fornecer uma quantidade de matéria orgânica similar àquelas fornecidas pelos biossólidos. Para isso adotou-se o critério de aplicar uma dose de carbono orgânico igual a $70 \%$ da maior dose deste elemento fornecida pelos biossólidos (39 e $43 \mathrm{~g} \mathrm{~kg}^{-1}$ do PVAd e $\mathrm{NVdl}$, respectivamente). Como o teor de $\mathrm{C}$ da turfa é $427,42 \mathrm{~g} \mathrm{~kg}^{-1}$, as doses desse material calculadas foram $64 \mathrm{e} 71$ $\mathrm{g} \mathrm{kg}^{-1}$, para o PVAd e o $N V d l$, respectivamente. Considerando-se as densidades dos solos, as dose de turfa calculadas corresponderam a aproximadamente $83 \mathrm{~kg} \mathrm{ha}^{-1}$.

\subsection{Cálculo das doses de níquel fornecido através de $\mathrm{NiCl}_{2}$}

As doses de Ni foram equivalentes a $21 \mathrm{~kg} \mathrm{ha}^{-1}$ e a $42 \mathrm{~kg} \mathrm{ha}^{-1}$ e obtidas através da adição do sal cloreto de níquel, $\mathrm{NiCh}_{2}$, ao solo. A definição destas doses foi baseada na taxa máxima de aplicação anual do metal, proposta pela legislação 40 da U.S. Environmental Protection Agency (Estados Unidos, 1993), que regulamenta o uso agrícola de biossólidos nos Estados Unidos.

Tabela 5. Dose de níquel via $\mathrm{NiCh}_{2}$ em função do solo e da dose turfa.

\begin{tabular}{ccccc}
\hline & $\begin{array}{c}\text { Dose de turfa } \\
(\mathrm{g})\end{array}$ & $\begin{array}{c}\text { Solo + turfa } \\
(\mathrm{g})\end{array}$ & $\left(\mathrm{kg} \mathrm{ha}^{-1}\right)$ & $(\mathrm{mg} / \mathrm{vaso})$ \\
\hline & zero & 3000,00 & 21 & 48,46 \\
$z$ & zero & 3000,00 & 42 & 96,92 \\
$z$ & 191,88 & 3191,88 & 21 & 51,56 \\
$z$ & 191,88 & 3191,88 & 42 & 103,12 \\
$z$ & zero & 3000,00 & 21 & 53,85 \\
& zero & 3000,00 & 42 & 107,69 \\
& 213,18 & 3213,18 & 21 & 57,67 \\
& 213,18 & 3213,18 & 42 & 115,34 \\
\hline
\end{tabular}


Com a adição de diferentes doses de turfa, as misturas "solo + matéria orgânica" adquiriram diferentes massas. Dessa forma, calculou-se a quantidade de sal de níquel a ser aplicada em cada tratamento tomando-se por base a massa da mistura e não da amostra de terra (Tabela 5).

\subsection{Montagem e condução dos ensaios em casa de vegetação}

$\mathrm{Na}$ montagem dos ensaios, os materiais dos tratamentos foram incorporados em amostras de $3 \mathrm{~kg}$ de solo, contidas em vasos de plástico com reservatórios individuais de água na parte inferior. Cordões de nylon, imersos na água, foram colocados em contato com o solo para manter, por ascensão capilar, a umidade dos tratamentos constante. A água consumida foi reposta periodicamente nos reservatórios.

Para proporcionar uma maior mineralização da matéria orgânica dos biossólidos e estimular a interação do níquel contido nestes materiais com os componentes dos solos, o ensaio com adição de Ni através de biossólidos foi iniciado 30 dias antes dos demais. Além de antecipar o inicio da incubação realizou-se o parcelamento da dose dos materiais duas incorporações separadas por um intervalo de 15 dias. O período total de incubação do referido ensaio foi de 150 dias.

Passados os 30 dias do início do primeiro ensaio, os outros dois foram instalados simultaneamente, com a incorporação de $\mathrm{NiCh}$, turfa e calcário às amostras de cada solo e posterior fornecimento de água aos reservatórios. A partir de então, foram contados 120 dias de incubação conduzida a temperatura ambiente.

Terminado o período de incubação previsto, o conteúdo de cada vaso, dos três experimentos, foi amostrado e reservado para a realização do fracionamento químico. 


\subsection{Introdução de plantas nos vasos}

A escolha da cultura a ser empregada como planta teste levou em consideração um conjunto de fatores como: ciclo relativamente curto, crescimento rápido, sistema radicular fasciculado e acúmulo de metais nos tecidos. Além disso, optou-se por uma cultura que normalmente é cultivada com adição de grandes quantidades de matéria orgânica e corre risco de acumular metais pesados. Atendendo aos requisitos propostos, a alface (Lactuca sativa L.) variedade Verônica, foi selecionada e utilizada como planta teste no estudo da biodisponibilidade do metal, a exemplo de uma série de trabalhos (John, 1973; Cravo, 1995).

Também na introdução e manutenção das plantas, os ensaios foram conduzidos simultaneamente, mantendo-se a independência destes e as posições determinadas anteriormente. As etapas comentadas a seguir serão válidas para os três ensaios.

Após a coleta das amostras de solos, efetuou-se o transplante das mudas das plantas para os vasos. Antes da introdução das mudas, realizou-se uma adubação com N P K em todos os vasos, como recomendado por Raij at al., (1996). Duas mudas de aproximadamente 10 centímetros de altura foram transplantadas para cada vaso, realizando-se um desbaste posterior para manutenção de apenas uma, que foi mantida por 50 dias. Após esse período, procedeu-se o corte, a secagem em estufa e a moagem das plantas, que foram reservadas para análises posteriores.

O conteúdo de cada vaso foi seco, peneirado e reservado para extração da solução do solo.

\subsection{Determinação do teor total de níquel}

Para a determinação dos teores totais de níquel, as amostras destinadas ao fracionamento químico foram digeridas por meio de aparelho de microondas com a mistura de $\mathrm{HNO}_{3}-\mathrm{HCl}-\mathrm{HF}$. Foram realizados testes com diversas misturas dos ácidos, condições de temperatura e tempo de digestão das amostras. Desta forma, procedeu-se a 
digestão de $0,5 \mathrm{~g}$ de solo utilizando-se a mistura de $3 \mathrm{~mL}$ de $\mathrm{HNO}_{3}+4 \mathrm{~mL}$ de $\mathrm{HCl}+5$ $\mathrm{mL}$ de $\mathrm{HF}$, em tubos de teflon fechados, denominados ACV (Advanced Composite Vessel), que suportam pressões de até 200 psi. As amostras foram irradiadas em forno de microondas CEM 2000, em duas etapas. A primeira etapa consistiu na irradiação das amostras com potência de $630 \mathrm{~W}$ e pressão máxima de 170 psi. O tempo de irradiação total foi de 50 minutos, sendo os 15 primeiros gastos para atingir a referida pressão. A segunda etapa consistiu na eliminação do excesso de HF e dissolução dos compostos pouco solúveis que eventualmente tenham se formados com o íon $\mathrm{F}^{-}$. Nesta etapa foi adicionado $1 \mathrm{~g}$ de cristais de $\mathrm{H}_{3} \mathrm{BO}_{3}$ e as amostras foram submetidas a uma segunda irradiação, com potência de $630 \mathrm{~W}$ e pressão máxima de 170 psi, por 15 minutos.

Os extratos foram transferidos com água deionizada para tubos de plástico e tiveram seus volumes controlados por medida de massa. Na transferência dos extratos foi utilizado o mínimo de água necessário para evitar diluições que dificultariam as determinações por espectrometria de absorção atômica.

As amostras também foram utilizadas para determinação do $\mathrm{pH}$ em água (relação solo:água 1:2,5).

\subsection{Determinação do teor de níquel no material vegetal}

Os teores de níquel nas amostras de plantas foram determinados no extrato de digestão nítrico-perclórica em aparelho de espectrometria de emissão atômica com fonte de plasma induzido.

\subsection{Fracionamento químico do níquel}

O fracionamento foi utilizado para avaliar a distribuição do $\mathrm{Ni}$ nas frações da fase sólida dos solos, em função das diversas condições impostas pelos experimentos. Com base nestes resultados, é possível inferir sobre a biodisponibilidade do metal, uma 
vez que as frações do metal na fase sólida controlam, em parte, a sua presença na solução do solo (Candelaria \& Chang, 1997).

Nos experimentos com adição de doses de calcário, $\mathrm{NiCh}_{2}$ e turfa, o fracionamento do $\mathrm{Ni}$ teve como objetivo principal avaliar como a distribuição do metal nos constituintes da fração sólida dos solos foi influenciada pelo $\mathrm{pH}$, teor total do $\mathrm{Ni}$ e teor de matéria orgânica. Objetivou-se com isso entender o comportamento do Ni no solo, mesmo quando adicionado através de materiais complexos, como biossólidos.

No experimento com adição de biossólidos, além das amostras dos solos incubadas, os próprios materiais orgânicos foram submetidos ao procedimento de fracionamento. A distribuição do $\mathrm{Ni}$ nas frações dos biossólidos pode ser útil para subsidiar a explicação dos comportamentos do metal, proveniente da adição desses materiais nos solos.

O procedimento utilizado no fracionamento resultou da adaptação das etapas descritas por Mann \& Ritchie (1993) e Ahnstrom \& Parker (1999) e consistiu na extração seqüencial do metal na seguinte ordem: extração do metal presente na solução do solo e ligado à fração trocável; metal ligado à fração carbonato; metal ligado à matéria orgânica; metal ligado aos óxidos de ferro, de alumínio e de manganês e extração do metal remanescente na fase sólida e resistente ao ataque dos extratores utilizados anteriormente. Inicialmente, realizou-se a determinação dos teores totais de níquel nas amostras, de modo a nortear o procedimento de fracionamento e verificar a sua eficiência.

As amostras reservadas para fracionamento foram moídas em almofariz de porcelana para promover uma melhor homogeneização de seus componentes, e facilitar a ação das soluções extratoras. O fracionamento foi conduzido utilizando-se amostra de 2,5 g de solo incubado ou biossólido, em tubos de centrífuga de $50 \mathrm{~mL}$. Foram efetuadas 3 repetições para cada amostra. 


\subsubsection{Fração trocável + solúvel}

A fração do níquel trocável + solúvel foi extraída adicionando-se $15 \mathrm{~mL}$ de $\mathrm{Sr}\left(\mathrm{NO}_{3}\right)_{2} \quad 0,1 \mathrm{~mol} \mathrm{~L} \mathrm{~L}^{-1}$ aos tubos, agitando-se por 2 horas a baixa velocidade. Realizou-se a centrifugação a $5000 \mathrm{rpm}$ por 5 minutos e o sobrenadante filtrado foi transferido para frasco de plástico de $100 \mathrm{~mL}$. Após repetir a operação, o solo foi lavado com $5 \mathrm{~mL}$ de

$\mathrm{NaCl} 0,1 \mathrm{~mol} \mathrm{~L}{ }^{-1}$, centrifugado e o sobrenadante colocado no frasco. Acrescentou-se $\mathrm{HNO}_{3}$ para obter concentração aproximada de $1 \%$ para evitar precipitação de metais e anotou-se a massa total da solução.

\subsubsection{Fração ligada aos carbonatos}

A extração da fração do níquel ligado a carbonato e bicarbonato foi conduzida apenas nas amostras cujos valores de $\mathrm{pH}$ se encontravam acima de 7,0, pois tal interação ocorre ocorrem apenas nesta condição. Realizaram-se 3 extrações com $15 \mathrm{~mL}$ de solução de NaOAc 1,0 mol L ${ }^{-1}$ ajustada a pH 5,0 com ácido acético, centrifugou-se e lavou-se com $\mathrm{NaCl} 0,1 \mathrm{~mol} \mathrm{~L}{ }^{-1}$. Como no caso anterior, acrescentou-se $\mathrm{HNO}_{3}$, anotou-se a massa total da solução que foi conservada em frasco de plástico.

\subsubsection{Fração ligada à matéria orgânica}

A próxima fração extraída foi aquela ligada à matéria orgânica, utilizando-se 5 $\mathrm{mL}$ de solução de $\mathrm{NaOCl} 5 \%$, ajustada a $\mathrm{pH}$ 8,5. As amostras foram agitandas por 30 minutos à temperatura de $95^{\circ} \mathrm{C}$ e centrifugadas a $5000 \mathrm{rpm}$ por 5 minutos e o sobrenadante recolhido em frascos de plástico de $100 \mathrm{~mL}$. O procedimento foi repetido por quatro vezes para eliminação total da matéria orgânica. Lavou-se o solo com $\mathrm{NaCl}$ $0,1 \mathrm{~mol} \mathrm{~L}$, acrescentou-se $\mathrm{HNO}_{3}$ e verificou-se a massa da solução. 


\subsubsection{Fração ligada aos óxidos de Fe e de Al e de Mn}

Para a extração do níquel ligado aos óxidos de $\mathrm{Fe}$ e de $\mathrm{Al}$, as amostras foram tratadas com $20 \mathrm{~mL}$ de solução $0,2 \mathrm{~mol} \mathrm{~L}^{-1}$ de oxalato de amônio, 0,2 mol L ${ }^{-1}$ de ácido oxálico e 0,1 mol L $\mathrm{L}^{-1}$ de ácido ascórbico ajustada a $\mathrm{pH} 3,0 \mathrm{com} \mathrm{NH}_{4} \mathrm{OH}$. Os tubos foram aquecidos a $95^{\circ} \mathrm{C}$ por 30 minutos, centrifugou-se, sendo o sobrenadante recolhido em frascos de plástico de $100 \mathrm{~mL}$. Quatro dessas extrações foram efetuadas até a cor do solo tornar-se cinza (sem ferro) e o sobrenadante amarelado, lavando-se o solo ao final com $\mathrm{NaCl}$ 0,1 mol L ${ }^{-1}$. Os extratos foram conservados congelados até a determinação do Ni.

\subsubsection{Fração residual}

A última fração extraída foi a residual, sendo o processo semelhante àquele realizado para determinação dos teores totais de metais. Da massa de solo restante, digeriu-se $0,5 \mathrm{~g}$ em microondas com a mistura $2 \mathrm{~mL}$ de $\mathrm{HNO}_{3}+3 \mathrm{~mL}$ de $\mathrm{HCl}+5 \mathrm{~mL}$ de HF. A quantidade dos ácidos $\mathrm{HNO}_{3}$ e $\mathrm{HCl}$ foi reduzida, em relação a utilizada na determinação do Ni total, pois a matéria orgânica das amostras já havia sido removida. Após a digestão das amostras, adicionou-se $1 \mathrm{~g}$ de cristais de ácido bórico e transferiu-se o extrato para frascos de plástico de $100 \mathrm{~mL}$.

\subsection{Extração da solução do solo}

A solução empregada no estudo de especiação do níquel foi obtida a partir da pasta de saturação. No preparo da referida pasta foram pesados $1000 \mathrm{~g}$ de cada amostra de terra e colocados em vasos de plástico. Adicionou-se água deionizada misturando continuamente até atingir o ponto de pasta saturada descrita por Rhoades, (1993) e a separação da fase líquida foi realizada por meio de filtragem das amostras em funis de Buchner, com ajuda de bomba de vácuo. Este procedimento resultou na obtenção de, em média, $60 \mathrm{~mL}$ de extrato por amostra de pasta de saturação, os quais foram submetidos à centrifugação por 2 minutos a $3000 \mathrm{rpm}$, com o objetivo de separar eventuais partículas suspensas. Essas soluções foram reservadas para medida de condutividade elétrica e 
determinação direta da atividade do níquel na solução do solo pela técnica do equilíbrio de Donnan.

\subsection{Medida da condutividade elétrica das soluções}

As medidas de condutividade elétrica foram realizadas diretamente nos extratos de pasta saturada, utilizando um condutivímetro digital DIGIMED DM 31. A medida da condutividade elétrica dos extratos de saturação possibilita a estimativa de sua força iônica e subsidia o ajuste das condições das soluções receptora e doadora no equilíbrio de Donnan.

\subsection{Especiação do Ni pelo Equilíbrio de Donnan}

A medida direta da atividade do íon $\mathrm{Ni}^{+2}$ no extrato de saturação foi baseada essencialmente no que descreve Fitch \& Helmke (1989).

O equilíbrio de Donnan foi estabelecido em uma célula construída em PVC com uma câmara na qual se obtém dois compartimentos, através da inserção de uma membrana trocadora de cátions (Figura 3). No compartimento superior são colocados 0,20 mL de uma solução denominada receptora, que entra em equilíbrio com volume de 60 a $80 \mathrm{~mL}$ de uma solução doadora, que circula em contato com a parte inferior da membrana, durante duas horas, por bombeamento a $10 \mathrm{~mL} \mathrm{~min}^{-1}$ através de bomba peristáltica.

A alta relação entre volumes de soluções doadora e receptora é proposital, pois se pretende que a solução doadora, em geral extrato de saturação de solo, seja perturbada o menos possível em relação aos equilíbrios químicos que nela ocorrem, mantendo suas características físico-químicas.

Medindo-se a condutividade elétrica da solução doadora, no caso o extrato de saturação, preparou-se uma solução receptora de $\mathrm{Sr}\left(\mathrm{NO}_{3}\right)_{2}$ de igual condutividade elétrica.. Somente quando se opera com soluções de força iônica similar, as atividades de equilíbrio das espécies que atravessam a membrana se tornam iguais. $O$ sal da 
solução receptora é escolhido de modo a não introduzir no equilíbrio uma espécie que se pretende estudar, nem que forme complexos, condições essas atendidas em grande parte dos casos pelos íons $\mathrm{Sr}^{+2}$ e $\mathrm{NO}_{3}{ }^{-}$, respectivamente.

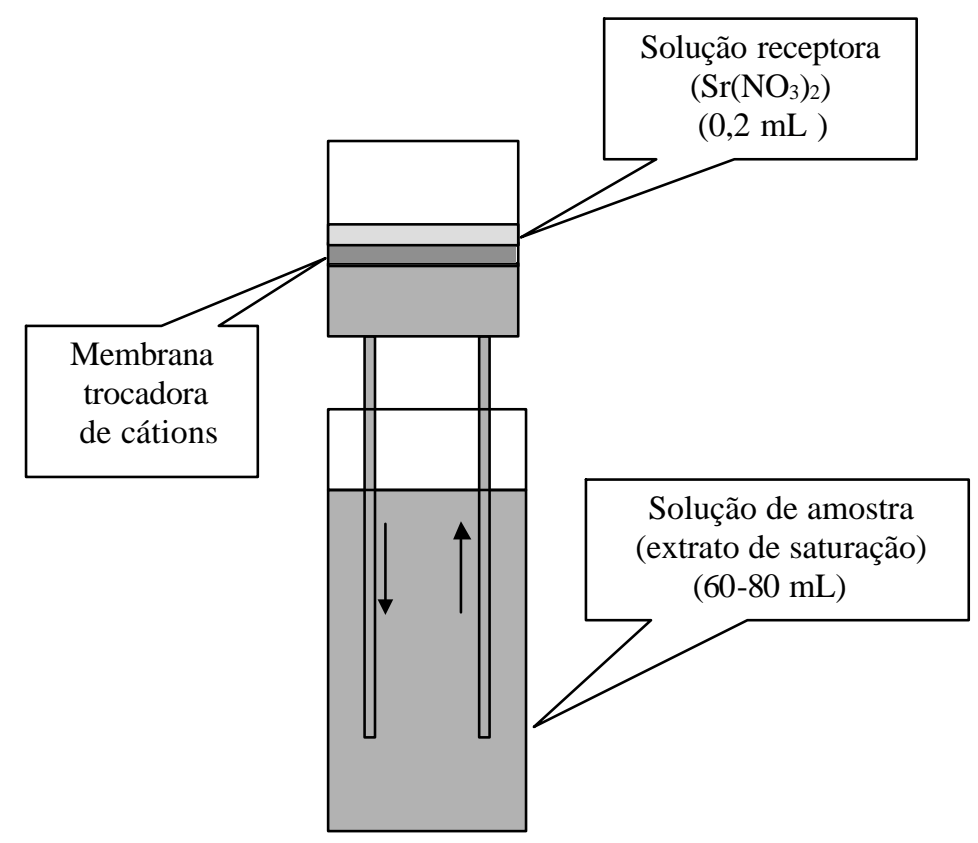

Figura 3 - Esquema na célula utilizada no procedimento de equilíbrio de Donnan.

A membrana trocadora de cátions utilizada foi a Nafion-117 da E.I. DuPont de Nemours Company. Trata-se de um polímero de tetrafluoretileno e éter vinil sulfonil flureto, com as seguintes características quando saturada com $\mathrm{Sr}^{+2}$ : espessura de 0,215 mm; conteúdo de água de 8,34 $\mathrm{mol} \mathrm{mol}^{-1} \mathrm{SO}_{3}$; capacidade de troca de $0,974 \mathrm{mmol} \mathrm{g}{ }^{-1}$. As membranas foram previamente preparadas para o uso, mantendo-as inicialmente em solução $0,1 \mathrm{~mol} \mathrm{\textrm {L } ^ { - 1 }} \mathrm{HNO}_{3}$ por 3 horas, para deslocamento de cátions eventualmente retidos. As membranas saturadas com $\mathrm{H}^{+}$foram depois equilibradas em solução 0,1 molL ${ }^{-1}$ de $\left(\mathrm{SrNO}_{3}\right)_{2}$ para que o íon $\mathrm{Sr}^{+2}$ ocupasse todos os sítios de troca catiônica, prevenindo a alteração de $\mathrm{pH}$ durante o equilíbrio. Isso foi conseguido através de sucessivas trocas da solução de nitrato de estrôncio, até que o pH se estabilizasse acima de 5 . 
Uma vez atingido o equilíbrio, a atividade dos cátions livres é igual nas duas soluções separadas pela membrana. A solução receptora é então coletada e reservada para as determinações analíticas previstas.

A análise química da solução receptora possibilita, portanto, a determinação da atividade dos cátions de interesse na solução doadora, que é a solução de amostra. Isso é possível porque, formas complexadas não atravessam a membrana em dreção à solução receptora. Os teores de $\mathrm{Ni}$ determinados nas soluções doadoras e receptoras foram denominados teor solúvel e teor livre de $\mathrm{Ni}$, respectivamente.

\subsection{Determinação analítica dos teores de níquel nos extratos}

Os teores totais de níquel do solo e os presentes nas frações da extração sequencial foram quantificados por espectrometria de absorção atômica com chama aracetileno. Amostras que apresentaram teores do metal abaixo do limite de deteç̧ão da técnica citada foram analisadas em aparelho de espectrometria de emissão atômica com fonte de plasma induzido, que tem um limite de detecção do $\mathrm{Ni}$ de $0,01 \mathrm{~mol} \mathrm{~L}^{-1}$. Este mesmo método foi utilizado para quantificar a concentração do $\mathrm{Ni}$ nas soluções receptoras nas soluções doadoras envolvidas na especiação pelo equilíbrio de Donnan.

\subsection{Análise estatística dos dados}

Os tratamentos estudados compuseram três experimentos fatoriais, sendo que dois constavam da aplicação de níveis de calcário, $\mathrm{NiCh}_{2}$ e turfa, em dois solos diferentes, um em cada experimento. Num terceiro experimento, os dois solos utilizados nos experimentos anteriores receberam uma única dose de quatro diferentes biossólidos. As análises de variância, as correlações lineares simples e o ajuste dos dados ao modelo de regressão múltipla foram realizados através do programa estatístico SAS (SAS, 1996). 


\section{RESULTADOS E DISCUSÃO}

\subsection{Teores de carbono orgânico, de níquel total e pH dos solos incubados}

Nos estudos de incubação de $\mathrm{NiCh}_{2}$ e diferentes biossólidos, as amostras de solo foram coletadas e analisadas para determinar os teores de carbono orgânico, níquel total e $\mathrm{pH}$. Na discussão que se segue pretende-se discutir como estes atributos refletiram os efeitos dos tratamentos estudados.

Devido à elevada precisão dos experimentos, somente foram consideradas significativas as variações que apresentaram valor de probabilidade de serem nulas menor que 0,01. Refletindo o alto grau de precisão das medidas para alguns parâmetros estudados foi detectado significância estatística para todas as causas de variação, mesmo sendo algumas delas responsáveis por alterações ínfimas, sem significado prático.

Para auxiliar a discussão dos resultados, foram enfatizados as causas de variação cuja soma de quadrados representava maior proporção da soma de quadrados total na análise de variância.

\subsubsection{Resultados dos ensaios com adição de $\mathrm{NiCl}_{2}$}

Após 120 dias de condução dos ensaios, a adição de matéria orgânica nos tratamentos através da turfa, resultou em incrementos similares no conteúdo de carbono orgânico dos solos PVAd e NVdl (Figura 4). 
Esse resultado está de acordo com o previsto, uma vez que quantidades também similares de turfa foram adicionadas aos dois solos, diferindo apenas ligeiramente por terem sido calculadas com base na densidade dos mesmos. Criou-se assim um diferencial expressivo de teor de carbono em cada solo, adequado para que se manifestasse um possível efeito da matéria orgânica na redução da disponibilidade dos metais pesados do solo, como descrito por Adriano (1986).

Com base nos valores de soma de quadrados da análise de variância dos dados de carbono (Tabela 6), pode-se verificar que a adição da turfa foi responsável por mais de 99\% das variações ocorridas nesse atributo em ambos os solos considerados. Dessa forma, o fator dose de matéria orgânica foi o único a afetar significativamente os teores de carbono orgânico.
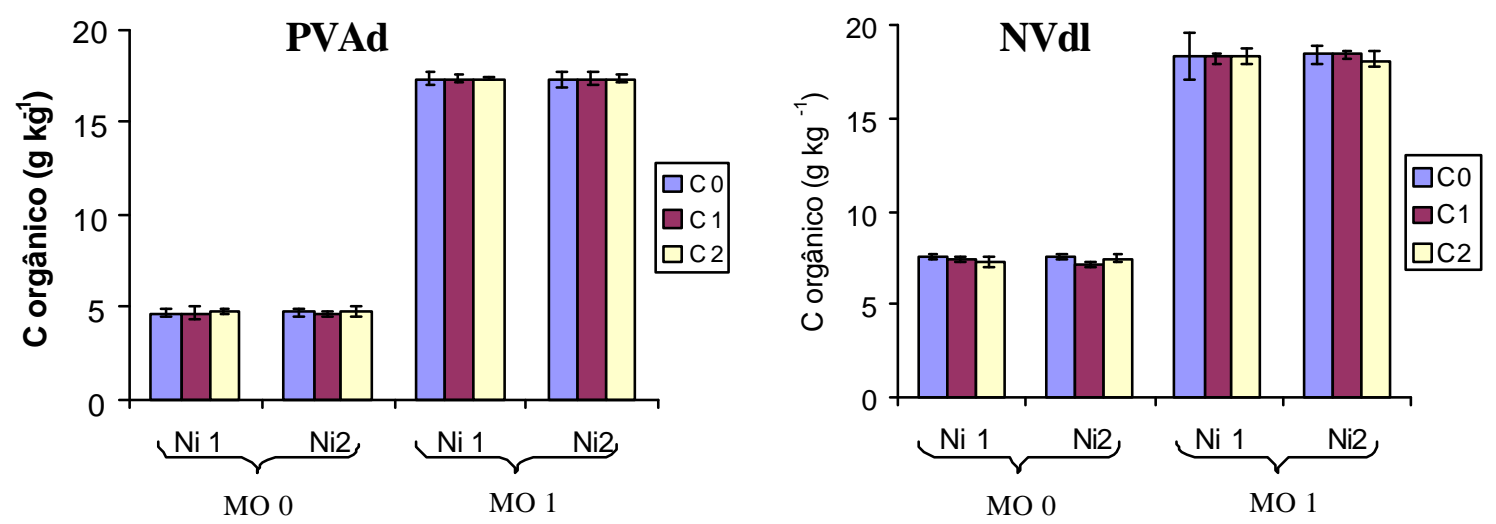

$\mathrm{C}=$ calcário; $\mathrm{MO}$ = matéria orgânica.

Figura 4 - Teor de carbono orgânico dos solos PVAd e NVdl, sob diferentes doses de calcário $\left(0 ; 0,64\right.$ e $2,87 \mathrm{~g} \mathrm{~kg}^{-1}$ e $0 ; 0,97$ e $3,29 \mathrm{~g} \mathrm{~kg}^{-1}$, respectivamente), matéria orgânica ( 0 e $83 \mathrm{Mg} \mathrm{ha}^{-1}$ ) e $\mathrm{NiCl}_{2}\left(21\right.$ e $42 \mathrm{~kg} \mathrm{ha}^{-1}$ ). Médias de 3 repetições.

A aplicação de calcário aos dois solos promoveu incrementos de $\mathrm{pH}$ no intervalo que se esperava para avaliar os possíveis efeitos desse fator sobre o comportamento de $\mathrm{Ni}$ nos solos (Figura 5). Pretendeu-se obter um intervalo de pH pela aplicação de calcário que incluísse os valores de $\mathrm{pH}$ em geral obtidos pela incubação ao solo de diferentes tipos de biossólidos. 
Tabela 6. Resumo da análise de variância, contendo os valores de soma dos quadrados (SQ) e de probabilidade (Pr) de significância pelo teste $\mathrm{F}$, dos dados de carbono orgânico, níquel total e pH, para um ARGISSOLO VERMELHO AMARELO Distrófico e um NiTOSSOLO VERMELHO Distrófico Latossólico tratados com $\mathrm{NiCh}_{2}$, calcário e turfa.

\begin{tabular}{|c|c|c|c|c|c|c|c|c|c|c|c|c|c|}
\hline \multirow{3}{*}{$\begin{array}{l}\text { Causas de } \\
\text { Variação }\end{array}$} & \multirow[t]{3}{*}{ G.L } & \multicolumn{6}{|c|}{ 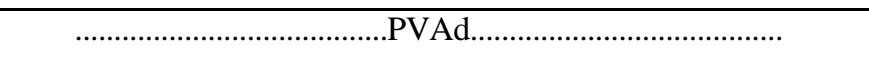 } & \multicolumn{6}{|c|}{ 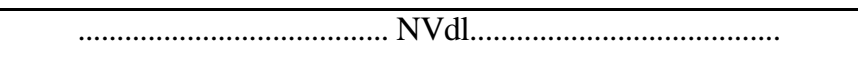 } \\
\hline & & \multicolumn{2}{|c|}{ C orgânico } & \multicolumn{2}{|c|}{ Ni total } & \multicolumn{2}{|c|}{$\mathrm{pH}$} & \multicolumn{2}{|c|}{ C orgânico } & \multicolumn{2}{|c|}{ Ni total } & \multicolumn{2}{|c|}{$\mathrm{pH}$} \\
\hline & & S. Q. & $\operatorname{Pr}>|F|$ & S. Q. & $\operatorname{Pr}>|F|$ & S. Q. & $\operatorname{Pr}>|F|$ & S. Q. & $\operatorname{Pr}>|F|$ & S. Q. & $\operatorname{Pr}>|F|$ & S. Q. & $\operatorname{Pr}>|F|$ \\
\hline Dose de MO & 1 & 1440,7 & 0,0001 & 0,366 & 0,6474 & 4,789 & 0,0001 & 1086,5 & 0,0001 & 9,766 & 0,0429 & 3,809 & 0,0001 \\
\hline Dose de Ni & 1 & 0,009 & 0,7196 & 2304,5 & 0,0001 & 0,058 & 0,0001 & $<0,001$ & 0,9972 & 2400,5 & 0,0001 & 0,039 & 0,0013 \\
\hline Dose de Calcário & 2 & 0,008 & 0,9490 & 6,110 & 0,1885 & 24,74 & 0,0001 & 0,140 & 0,7256 & 1,259 & 0,7473 & 15.00 & 0,0001 \\
\hline $\mathrm{MO} * \mathrm{Ni}$ & 1 & 0,002 & 0,8574 & 0,002 & 0,9768 & $<0,001$ & 0,9100 & 0,010 & 0,8342 & 3,222 & 0,2313 & 0,004 & 0,2705 \\
\hline MO *Calcário & 2 & 0,023 & 0,8415 & 0,833 & 0,7854 & 1,920 & 0,0001 & 0,067 & 0,8575 & 0,702 & 0,8495 & 0,832 & 0,0001 \\
\hline $\mathrm{Ni}^{*}$ Calcário & 2 & 0,001 & 0,9918 & 1,819 & 0,5937 & 0,215 & 0,0001 & 0,010 & 0,9765 & 5,027 & 0,3254 & 0,008 & 0,2632 \\
\hline MO*Ni*Calcário & 2 & 0,014 & 0,8988 & 0,317 & 0,9116 & 0,021 & 0,0109 & 0,225 & 0,6001 & 3,955 & 0,4094 & 0,005 & 0,4270 \\
\hline Resíduo & 24 & 1,585 & - & 40,95 & - & 0,046 & - & 5,184 & - & 51,26 & - & 0,072 & - \\
\hline Total & 35 & 1442,4 & - & 2354,9 & - & 31,79 & - & 1092,1 & - & 2475,7 & - & 19,77 & - \\
\hline
\end{tabular}


Embora a análise de variância para $\mathrm{pH}$ (Tabela 6) tenha revelado altas probabilidades de significância para a maioria das possíveis causas de variação, pode-se verificar pelos valores de soma de quadrados, que os efeitos do calcário, da turfa e da interação entre eles explicam 99 \% das alterações do atributo, em ambos os solos.

A precisão elevada observada nas medidas de $\mathrm{pH}$ condiciona igualmente precisão elevada do ensaio, ou seja, valores baixos para o soma de quadrados do resíduo. Assim, pequenas variações no parâmetro acabam por ser significantes estatisticamente, apesar de não terem sentido prático.

A adição de calcário foi a principal responsável pelas mudanças do $\mathrm{pH}$ solo, explicando $78 \%$ das variações deste atributo no PVAd e 76\% no NVdl (Tabela 6).

A aplicação de turfa afetou o pH dos solos, explicando 15 e $19 \%$ das variações desse atributo no PVAd e NVdl, respectivamente, apenas pelo seu efeito isolado (Tabela 6). Na Figura 5 é possível observar que o material orgânico atuou no sentido de promover decréscimos nos valores de $\mathrm{pH}$, a exemplo do que foi verificado por Reis (1998), ao estudar o efeito de diversas fontes de matéria orgânica na reação do solo. Assim como no referido trabalho, esse efeito pode ser atribuído à acidez intrínseca da turfa, que apesar de ter passado por uma neutralização prévia, demonstrou ainda conter acidez residual.

A interação matéria orgânica $x$ calcário também foi considerada relevante na variação do $\mathrm{pH}$ dos solos, pois explicou 6 e $4 \%$ das alterações no PVAd e NVdl, respectivamente (Tabela 6). Através desta interação, observa-se que as doses do corretivo resultaram em menores acréscimos na variável analisada, em presença da turfa (Figura 5).

Cabe considerar que, embora o $\mathrm{pH}$ do solo seja um parâmetro de fácil determinação e traga informações úteis sobre a reação dos solos, deve-se ter um certo cuidado ao relacioná-los com a variação da acidez dos mesmos. O pH reflete a concentração dos íons $\mathrm{H}^{+}$porém, numa relação logarítmica. Embora as variações de $\mathrm{pH}$ entre 3,0 e 4,0; e entre 6,0 e 7,0 sejam de uma unidade, a variação em concentração hidrogeniônica é 1000 vezes maior no primeiro caso. 

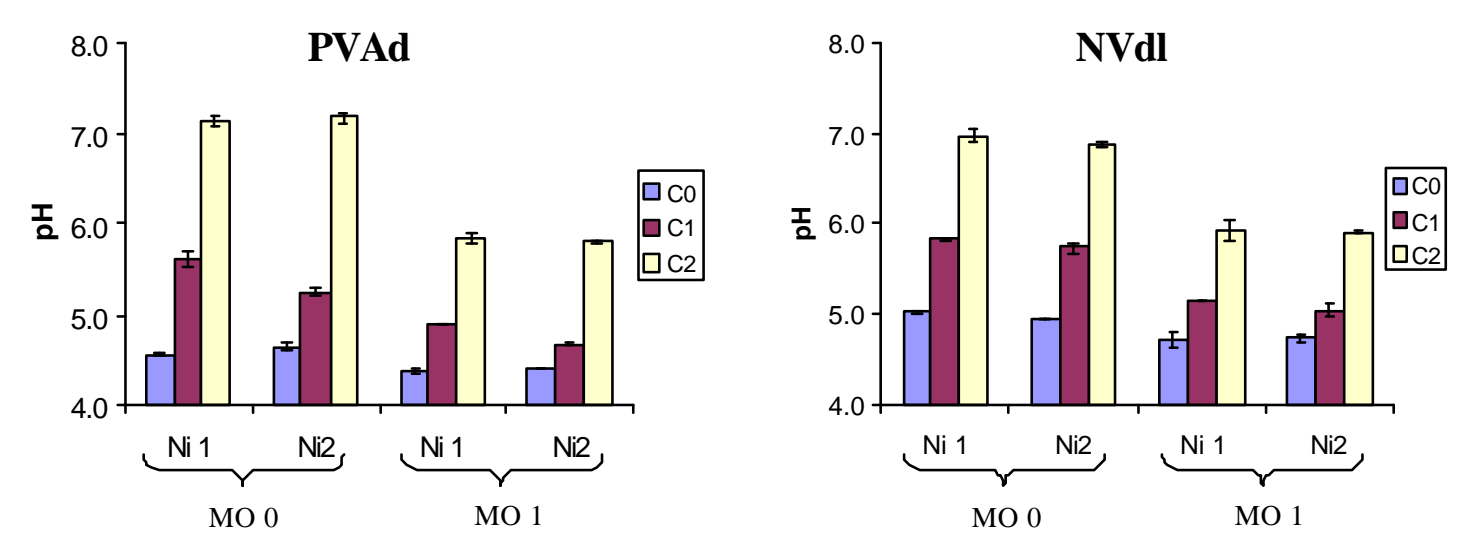

$\mathrm{C}=$ calcário $\mathrm{MO}=$ matéria orgânica.

Figura 5 - Valores de $\mathrm{pH}$ dos solos PVAd e NVdl, sob diferentes doses de calcário (0; 0,64 e $2,87 \mathrm{~g} \mathrm{~kg}^{-1}$ e $0 ; 0,97$ e $3,29 \mathrm{~g} \mathrm{~kg}^{-1}$, respectivamente), matéria orgânica (0 e $\left.83 \mathrm{Mg} \mathrm{ha}^{-1}\right)$ e $\mathrm{NiCh}_{2}\left(21\right.$ e $\left.42 \mathrm{~kg} \mathrm{ha}^{-1}\right)$. Médias de 3 repetições.

Os teores de níquel total (Figura 6) refletem perfeitamente as doses aplicadas do metal, correspondentes a 21 e $42 \mathrm{~kg} \mathrm{ha}^{-1}$. Essa observação pode ser confirmada pela análise de variância, que aponta o fator dose de $\mathrm{Ni}$ como a única causa de variação a promover alterações significativas na variável resposta em questão (Tabela 6).
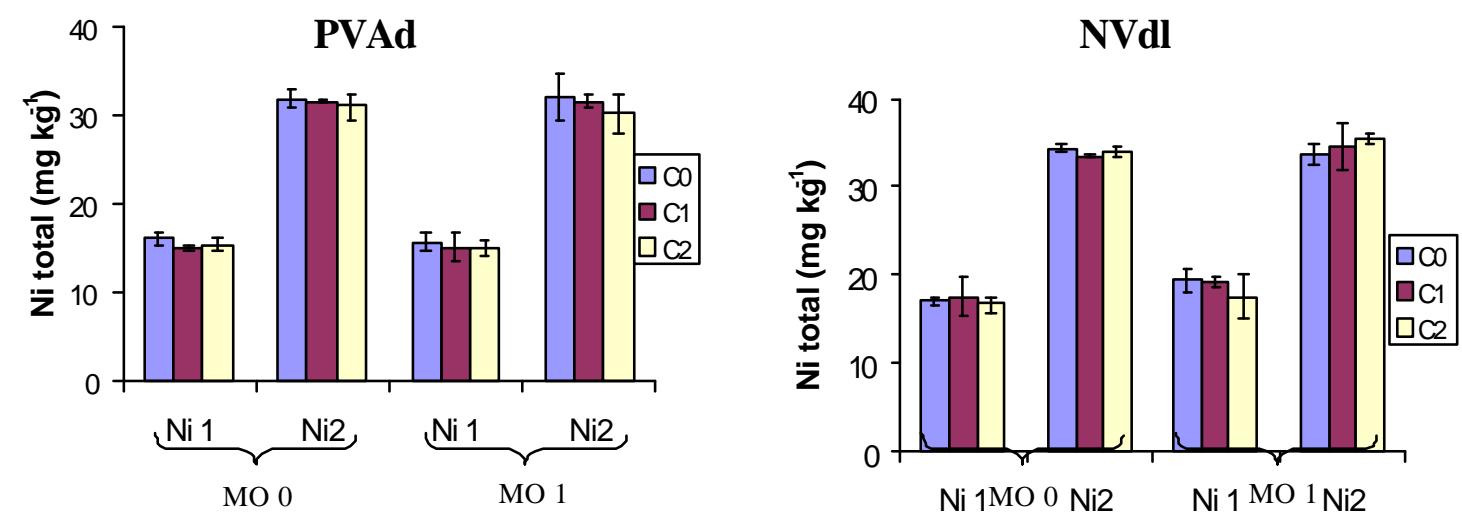

$\mathrm{C}=$ calcário; $\mathrm{MO}$ = matéria orgânica.

Figura 6 -Teores de Ni total dos solos PVAd e NVdl, sob diferentes doses de calcário (0; 0,64 e 2,87 $\mathrm{g} \mathrm{kg}^{-1}$ e $0 ; 0,97$ e 3,29 $\mathrm{g} \mathrm{kg}^{-1}$, respectivamente), matéria orgânica (0 e $\left.83 \mathrm{Mg} \mathrm{ha}^{-1}\right)$ e $\mathrm{NiCh}_{2}\left(21\right.$ e $\left.42 \mathrm{~kg} \mathrm{ha}^{-1}\right)$. Médias de 3 repetições. 
Os altos teores de $\mathrm{Ni}$ verificados após a adição das duas doses de $\mathrm{NiCh}$, possibilitaram a detecção deste metal nas diversas frações dos solos e a verificação do efeito da concentração total na sua distribuição.

\subsubsection{Resultados do ensaio com adição de biossólidos}

De maneira geral, os tipos de biossólidos e de solos foram os responsáveis pelas variações dos teores de carbono orgânico, $\mathrm{Ni}$ total e valores de $\mathrm{pH}$, sendo que a maior parte destas foi causada pelo primeiro fator (Anexo 1).

Os teores de carbono orgânico nos solos (Tabela 7) puderam ser relacionados diretamente à composição dos biossólidos ( $\mathrm{R}=0,93$ no PVAd e 0,95 no NVdl), variando segundo a ordem de teor de carbono orgânicos nos materiais: ETE Franca > ETE Jundiaí $>$ ETE Suzano > ETE Barueri (Tabela 3).

Silva (1995) não detectou acréscimos significativos de C orgânico no solo após 146 dias da aplicação de biossólido nas doses 20 e $40 \mathrm{Mg} \mathrm{ha}^{-1}$, indicando que este elemento foi rapidamente mineralizado. Contudo, a dose dos biossólidos aplicada no presente trabalho, $150 \mathrm{Mg} \mathrm{ha}^{-1}$, foi suficiente para resultar em teores de carbono orgânico maiores do que os das testemunhas $\left(5\right.$ e $7,5 \mathrm{~g} \mathrm{~kg}^{-1}$, para o PVAd e NVdl, respectivamente) e dentro da faixa de variação obtida com a adição de turfa.

O efeito da aplicação dos biossólidos sobre o $\mathrm{pH}$ do solo (Tabela 7) variou conforme a origem do material, que por sua vez reflete as diferenças do processo gerador dos mesmos. Obtiveram-se altos coeficientes de correlação entre os valores de $\mathrm{pH}$ dos biossólidos (Tabela 3) e os valores de $\mathrm{pH}$ dos solos incubados com os mesmos (0,94 no PVAd e 0,92 no NVdl). As maiores elevações desse parâmetro avaliado foram obtidas nos tratamentos que receberam os biossólidos provenientes das ETE de Barueri e Suzano, ambos tratados com cal. Nestes casos, as alterações de pH são resultado da reação dos componentes alcalinizantes adicionados aos materiais (Korcak, 1980 e Reis, 1998). O biossólido proveniente da ETE de Franca, tratado com polieletrólitos, e o de Jundiaí, que 
não recebeu nenhum condicionamento químico, não elevaram o $\mathrm{pH}$ do solo por não conterem agentes alcalinizantes na sua composição.

De forma semelhante aos teores de carbono e aos valores de $\mathrm{pH}$, os teores de $\mathrm{Ni}$ total nos tratamentos que receberam biossólidos refletiram a composição dos materiais aplicados $(\mathrm{R}=0,99$ em ambos os solos). Os níveis de Ni total, obtidos através da adição dos biossólidos, estão dentro da faixa de concentração do metal estabelecida pala adição do sal $\mathrm{NiCh}_{2}$.

Tabela 7. Teores de carbono orgânico, Ni total e valores de $\mathrm{pH}$ dos solos sob diferentes doses de biossólido. Médias de 3 repetições.

\begin{tabular}{|c|c|c|c|c|c|c|c|c|c|c|c|c|c|}
\hline \multirow{2}{*}{ Biossólido } & \multirow{2}{*}{$\begin{array}{l}\text { Tratamento } \\
\text { químico }\end{array}$} & \multicolumn{6}{|c|}{ PVAd } & \multicolumn{6}{|c|}{ NVdl. } \\
\hline & & $\mathrm{C}$ & $\mathrm{CV}$ & Ni total & $\mathrm{CV}$ & $\mathrm{pH}$ & $\mathrm{CV}$ & $\mathrm{C}$ & $\mathrm{CV}$ & Ni total & $\mathrm{CV}$ & $\mathrm{pH}$ & $\mathrm{CV}$ \\
\hline & & $\mathrm{g} \mathrm{kg}^{-1}$ & $\%$ & $\mathrm{mg} \mathrm{kg}^{-1}$ & $\%$ & & $\%$ & $\mathrm{~g} \mathrm{~kg}^{-1}$ & $\%$ & $\mathrm{mg} \mathrm{kg}^{-1}$ & $\%$ & & $\%$ \\
\hline Jundiaí & Nenhum & 17,03 & 0,98 & 11,71 & 1,90 & 4,73 & 1,61 & 17,95 & 2,02 & 13,01 & 1,90 & 4,08 & 1,58 \\
\hline Franca & polieletrólito & 17,13 & 1,68 & 12,10 & 4,88 & 5,04 & 1,03 & 18,33 & 1,63 & 13,44 & 4,88 & 4,58 & 1,67 \\
\hline Barueri & $\mathrm{FeCl}_{3}$ e cal & 9,84 & 1,69 & 18,41 & 0,63 & 8,24 & 1,70 & 12,81 & 2,25 & 21,45 & 2,00 & 7,98 & 0,96 \\
\hline Suzano & $\mathrm{FeCl}_{3}$ e cal & 12,09 & 1,19 & 25,35 & 6,15 & 7,86 & 0,81 & 15,21 & 1,09 & 28,17 & 6,15 & 7,68 & 0,38 \\
\hline
\end{tabular}

Os biossólidos provenientes de Suzano e Barueri são obtidos a partir de esgotos com maior contribuição de resíduos industriais, enquanto que nos de Jundiaí e Franca ocorre a predominância de resíduos domésticos. Isso explica porque os dois últimos apresentaram teor de níquel inferior aos primeiros.

\subsection{Resultados do fracionamento do níquel presente nos biossólidos}

$\mathrm{O}$ estudo de fracionamento de metais visa principalmente entender a distribuição dos mesmos no solo. Contudo, é usual aplicar o mesmo esquema de extração seqüencial a outras matrizes, como sedimentos (Tessier et al., 1979), resíduos industriais (Amaral Sobrinho et al., 1997), biossólidos (McGrath \& Cegarra, 1992), entre outros. 
No presente estudo também se julgou oportuno conhecer as formas de ocorrência do níquel nos biossólidos estudados, sobretudo porque esse material pode permanecer no solo por períodos relativamente longos sem sofrer alterações pronunciadas.

Considerando-se o conjunto dos biossólidos estudados, a soma das diversas frações de Ni determinadas pelo método de fracionamento representou em media $70 \%$ dos teores totais do metal determinados analiticamente (Tabela 3). Mesmo diferindo em termos de valores absolutos dos teores totais determinados, os teores do metal recuperado pelas extrações seqüenciais apresentaram alta correlação com os mesmos (Figura 7).

Apesar da porcentagem de recuperação ser relativamente baixa, o fracionamento do Ni nos biossólidos utilizados no experimento de incubação se mostrou eficiente na caracterização das formas em que o metal foi adicionado aos solos. Conforme será evidenciado posteriormente, estas informações são de extrema importância para a discussão da distribuição do $\mathrm{Ni}$ nos solos incubados com os referidos biossólidos, pois subsidiam as interpretações dos resultados.

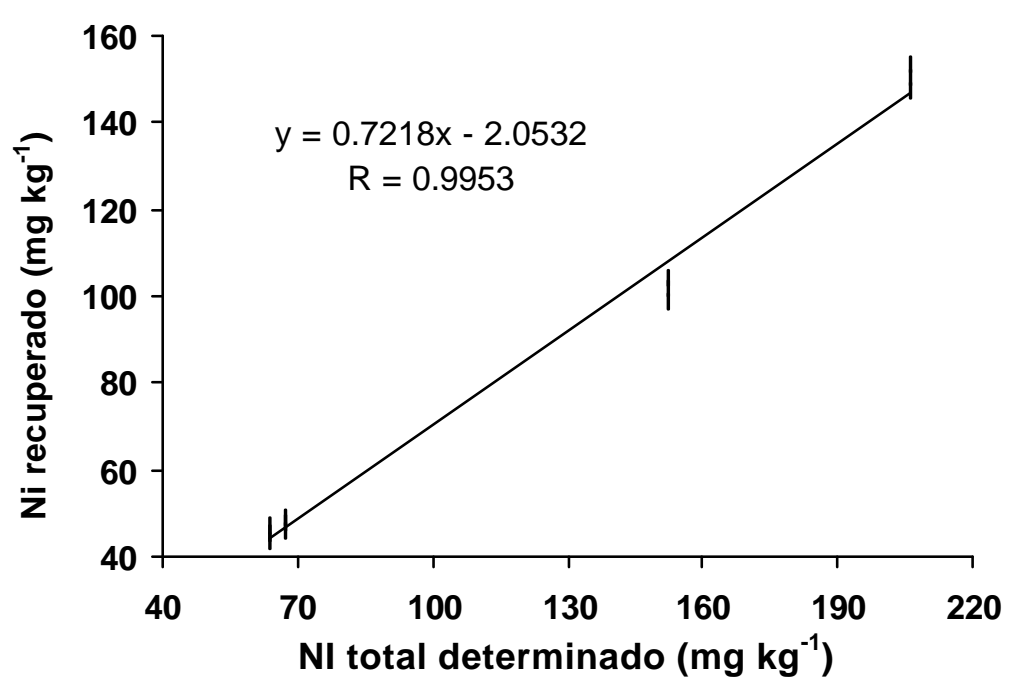

Figura 7 - Correlação entre teores totais de Ni determinados nos biossólidos e teores do metal obtidos pela soma das frações da extração sequencial. 
Observando-se a distribuição do Ni nos biossólidos (Figura 8), nota-se que a distribuição do níquel entre as frações são similares nos materiais provenientes das ETEs de Jundiaí e Franca. O metal nestes biossólidos encontra-se predominantemente na fração residual, seguida pelas frações: óxidos, matéria orgânica, trocável e carbonatos. Apesar destes materiais orgânicos resultarem de processos de obtenção distintos, não foram observadas maiores diferenças, além do teor trocável de $\mathrm{Ni}$ ligeiramente maior no biossólido de Franca.

Jundiaí

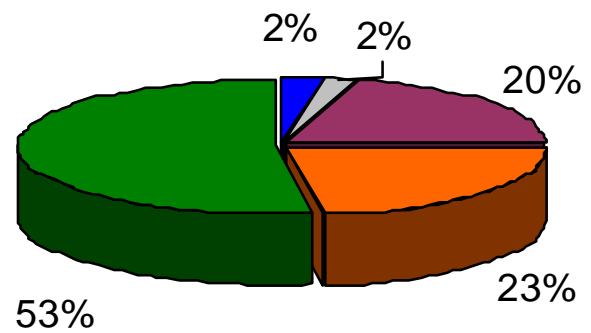

Barueri

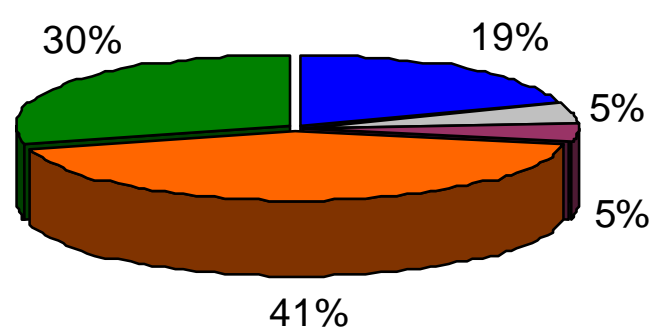

\section{Franca}

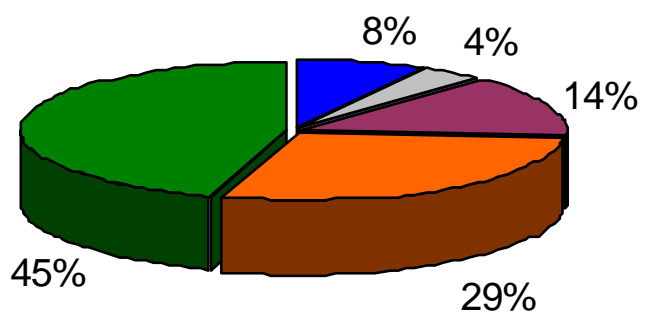

Suzano

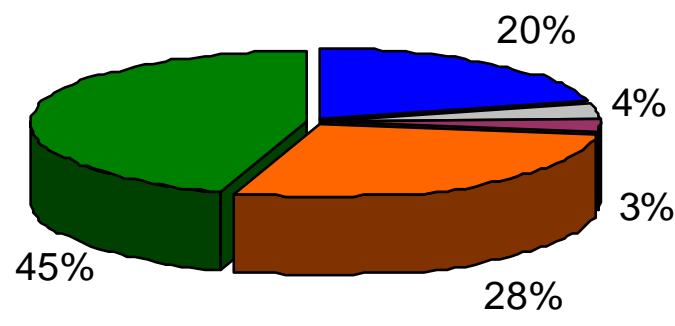

घtrocável $\square$ carbonato $\square$ matéria orgânica $\square$ óxidos $\square$ residual

Figura 8 - Distribuição de Ni ligado aos diversos componentes dos biossólidos. 
Os biossólidos tratados com cal e cloreto férrico, provenientes de Barueri e Suzano, além de possuírem composições químicas semelhantes (Tabela 3), apresentaram distribuições semelhantes do $\mathrm{Ni}$, refletindo a coincidência dos seus processos de obtenção. As frações residual e óxidos predominaram nos dois biossólidos alcalinos, sendo que naquele proveniente de Barueri a fração óxidos supera as demais, bem como é maior que a fração óxidos de qualquer outro biossólido.

Nos biossólidos de Barueri e Suzano nota-se ainda uma maior proporção do metal na fração trocável e uma menor porcentagem do metal ligado à matéria orgânica.

A ocorrência de maiores teores de $\mathrm{Ni}$ retido na fração residual, na maioria dos biossólidos, concorda com os resultados encontrados na literatura (Hickey \& Kittrick,1984; Gomes, 1996 e Pierrisnard, 1996). Entretanto, Bertoncini (2002) encontrou o Ni preferencialmente ligado a fração matéria orgânica, seguida das frações óxidos, residual, carbonato e trocável.

É importante notar que, a exemplo da composição dos biossólidos, a distribuição dos metais pode ser bastante variada. McGrath \& Cegarra (1992) fracionaram três amostras de biossólidos, coletadas em diferentes épocas numa mesma estação de tratamento e os resultados obtidos revelam grande variação da distribuição do Ni nas frações dos materiais.

\subsection{Fracionamento químico do Ni dos solos nos ensaios de incubação}

Com o fracionamento das amostras dos experimentos que receberam doses de calcário, $\mathrm{NiCl}_{2}$ e turfa, procurou-se isolar os efeitos do $\mathrm{pH}$, teor total de $\mathrm{Ni}$ e matéria orgânica sobre a distribuição do metal nos constituintes da fração sólida dos solos. Tais resultados foram comparados aos obtidos no fracionamento do metal adicionado através de biossólidos. 


\subsubsection{Eficiência do procedimento}

De maneira geral, os resultados da extração sequencial nas amostras de solo incubadas com calcário, turfa e $\mathrm{o}$ sal $\mathrm{NiCh}$ foram satisfatórios, pois a maior parte do níquel adicionado aos tratamentos foi recuperada (Tabelas 8).

Mesmo as menores recuperações de $\mathrm{Ni}$ nos tratamentos com adição de $\mathrm{NiCb}$ podem sem consideradas normais, um vez que a recuperação total dos metais adicionados dificilmente é alcançada em estudos desta natureza (McGrath \& Cegarra, 1992, Bertoncini, 2002). A Uma das criticas aos métodos de extração sequencial é a de que os erros da extração de uma fração se somam aos da fração seguinte, resultando em diferenças tanto para mais como para menos (Pierrisnard, 1996).

Tabela 8. Porcentagem de níquel recuperado pelo fracionamento em relação ao teor total determinado dos solos PVAd e NVdl, sob diferentes doses de calcário $(0 ; 0,64$ e $2,87 \mathrm{~g} \mathrm{~kg}^{-1}$ e $0 ; 0,97$ e $3,29 \mathrm{~g} \mathrm{~kg}^{-1}$, respectivamente), matéria orgânica ( 0 e 83 $\left.\mathrm{Mg} \mathrm{ha}^{-1}\right)$ e $\mathrm{NiCh}_{2}\left(21\right.$ e $\left.42 \mathrm{~kg} \mathrm{ha}^{-1}\right)$. Médias de 3 repetições.

\begin{tabular}{|c|c|c|c|c|c|c|c|c|}
\hline & \multicolumn{4}{|c|}{ 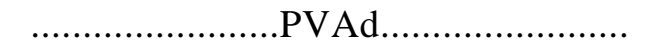 } & \multicolumn{4}{|c|}{ 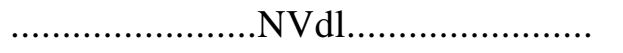 } \\
\hline & \multicolumn{2}{|c|}{........MO 1 1........... } & \multicolumn{2}{|c|}{$\ldots \ldots . . \mathrm{MO} 2 \ldots \ldots \ldots$} & \multicolumn{2}{|c|}{........MO $1 \ldots \ldots \ldots}$. & \multicolumn{2}{|c|}{........MO 2........ } \\
\hline & Ni 1 & Ni 2 & Ni 1 & Ni 2 & Ni 1 & Ni 2 & Ni 1 & Ni 2 \\
\hline & & & & &.. & $\ldots$ & 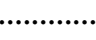 & . \\
\hline $\mathrm{C} 0$ & 103,05 & 93,83 & 85,52 & 96,45 & 93,80 & 85,58 & 81,47 & 85,41 \\
\hline $\mathrm{C} 1$ & 105,47 & 105,28 & 89,86 & 97,45 & 91,32 & 79,98 & 85,89 & 75,83 \\
\hline $\mathrm{C} 2$ & 118,83 & 100,70 & 79,15 & 78,59 & 100,58 & 90,90 & 84,86 & 75,56 \\
\hline
\end{tabular}

$\overline{\mathrm{C}}=$ calcário; $\mathrm{MO}=$ matéria orgânica.

De maneira geral, os menores valores de recuperação do Ni concentram-se nas maiores doses de calcário. Nessas condições, os maiores valores de $\mathrm{pH}$ do solo, ao mesmo tempo em que favorecem a retenção de metais pela matéria orgânica (Uren, 1992 e Mc Grath, 1995), diminuem a eficiência de sua extração pelo hipoclorito de sódio, o que pode explicar as menores recuperações (Tabela 8). Egreja Filho (2000) relata que durante a extração do Ni ligado à matéria orgânica podem ocorrer precipitações, devido ao elevado $\mathrm{pH}$ e ao caráter oxidante do $\mathrm{NaOCl} 5 \%$. A baixa recuperação do elemento na 
fração orgânica tem levado alguns autores a concluírem que o $\mathrm{Ni}$ apresenta pouca afinidade com a matéria orgânica.

Mesmo que os resultados do fracionamento não correspondam aos valores reais de concentração dos metais nas diferentes formas, estes podem apresentar coerência em termos relativos. Isto os tornam de grande utilidade para estabelecer comparações entre os diversos tratamentos e assim elucidar o comportamento do metal nos solos.

O fracionamento também se mostrou eficiente na extração do níquel incorporado aos solos através dos biossólidos, no ensaio com estes materiais. A porcentagem de recuperação do metal pelo processo variou entre 91 e $108 \%$ do teor total determinado (Tabela 9). Tais valores podem ser considerados satisfatórios, tendo em vista a gama de fontes de erros a que a metodologia está sujeita. Utilizando o mesmo método de fracionamento do presente trabalho, Bertoncini (2002) recuperou de 85 a $103 \%$ do $\mathrm{Ni}$ adicionado ao solo por biossólidos.

Tabela 9. Porcentagem de níquel recuperado pelo fracionamento dos tratamentos com biossólidos, em relação ao teor total determinado, médias de três repetições.

\begin{tabular}{|c|c|c|c|c|}
\hline & Jundiaí & Franca & Barueri & Suzano \\
\hline & & & & \\
\hline PVAd & 107 & 108 & 97 & 95 \\
\hline NVdl & 105 & 97 & 101 & 91 \\
\hline
\end{tabular}

Foram encontradas algumas dificuldades durante a realização do procedimento de fracionamento. Na extração do Ni ligado à matéria orgânica, por exemplo, apesar do hipoclorito de sódio ser eficiente na remoção do metal (Beckett, 1989), este apresentou problemas na determinação deste por espectrometria de absorção atômica. Os extratos ocasionavam acúmulo de sais e entupimento do queimador do equipamento, requerendo limpezas após a leitura de um número relativamente pequeno de amostras. Bertoncini (2002) também detectou esse inconveniente do hipoclorito. 
Para cada fração, o ajuste da composição da matriz dos extratos com as das soluções padrões utilizadas na determinação dos teores do metal, também se mostrou um ponto passível de erros do método. A curva padrão de cada fração foi elaborada utilizando os mesmos reagentes presentes na solução extratora em questão. Apesar desse cuidado, o efeito de matriz foi nitidamente percebido, na maioria das frações, devido à remoção de outros componentes do solo além do $\mathrm{Ni}$, que interferem na determinação do metal.

\subsubsection{Distribuição do Ni entre as frações}

O processo de extração seqüencial foi aplicado a solos que receberam níquel de duas fontes diferentes: sal e biossólido. É de se esperar, portanto, que a distribuição $\mathrm{Ni}$ nos solos reflita essa diferença, conforme será discutido a seguir.

Vale destacar ainda, que na etapa menos enérgica da extração eqüencial, quando se determinam os teores de metais extraídos pela solução de $\operatorname{Sr}\left(\mathrm{NO}_{3}\right)_{2}$, obtém-se a soma das frações solúvel + trocável, embora isso nem sempre seja destacado. No presente trabalho, a determinação de $\mathrm{Ni}$ solúvel no extrato de saturação permitiu entender melhor como essa fração se compõe, conforme será discutido com mais detalhes em 4.4.

\subsubsection{Resultados dos ensaios com adição de $\mathrm{NiCl}_{2}$}

Através do procedimento de extração sequencial obteve-se as mais variadas distribuições do $\mathrm{Ni}$ nas frações dos solos, em função da combinação dos fatores considerados nos ensaios. Uma característica constante nos resultados foi a ocorrência deste metal em apenas três das frações avaliadas: trocável, orgânica e óxidos (Figuras 9 e $10)$.

De maneira geral, dentro de cada solo, pode-se observar que a redução dos teores de Ni trocável foi acompanhada pelo aumento das frações orgânica e óxidos, e vice-versa. 


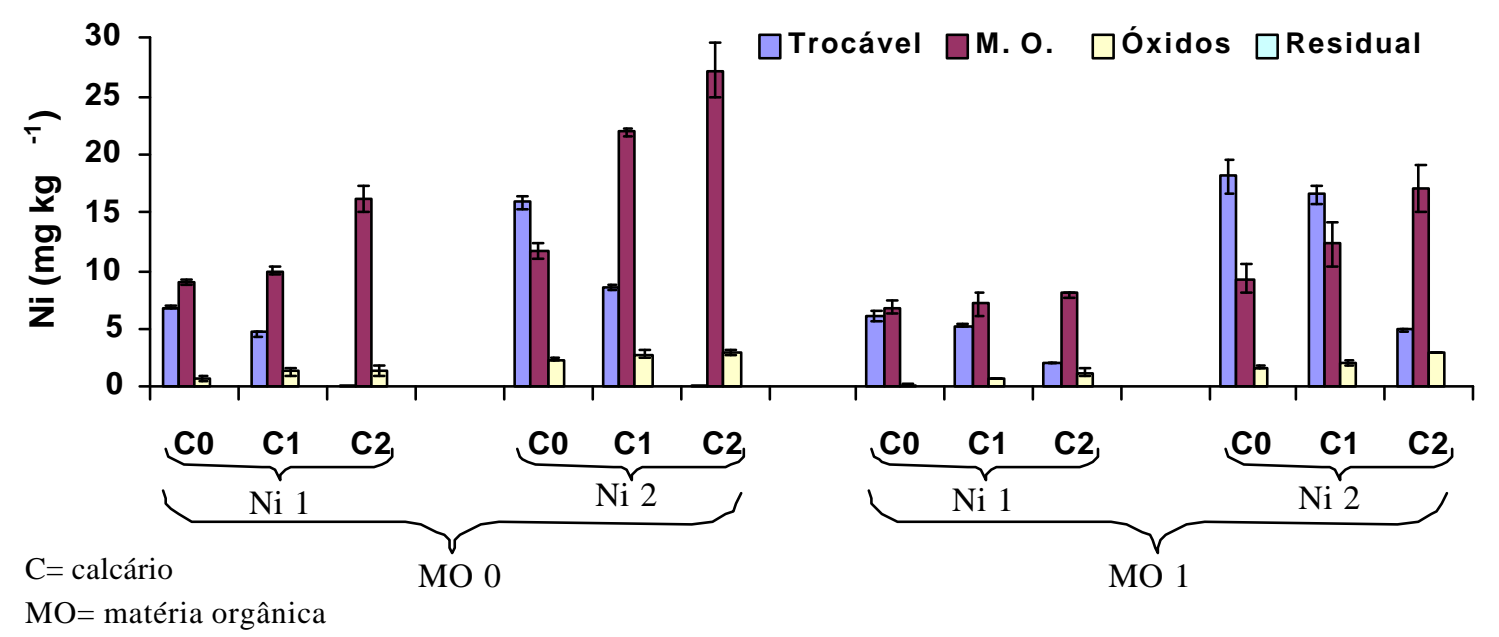

Figura 9 - Teores de níquel nas frações do PVAd, sob diferentes doses de calcário (0; 0,64 e $\left.2,87 \mathrm{~g} \mathrm{~kg}^{-1}\right)$, matéria orgânica (0 e $\left.83 \mathrm{Mg} \mathrm{ha}^{-1}\right)$ e NiCh $\left(21\right.$ e $\left.42 \mathrm{~kg} \mathrm{ha}^{-1}\right)$. Médias de 3 repetições.

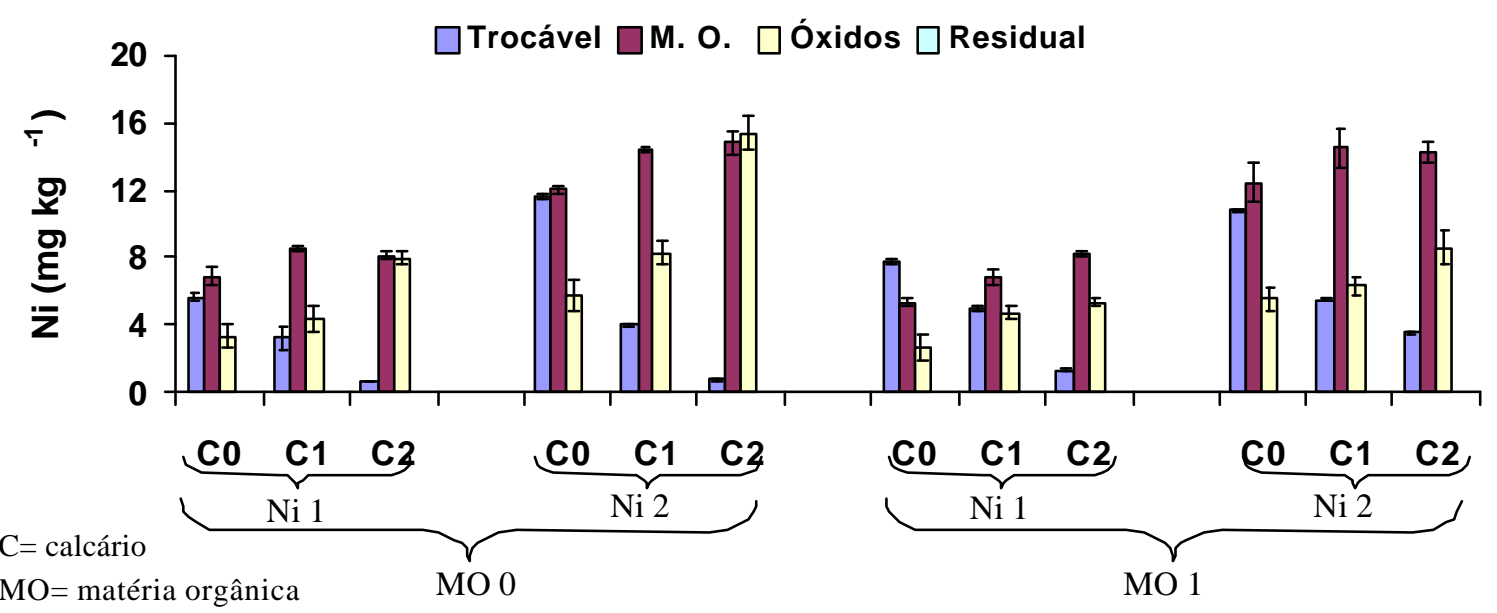

Figura 10 - Teores de níquel nas frações do NVdl sob diferentes doses de calcário (0; 0,97 e $\left.3,29 \mathrm{~g} \mathrm{~kg}^{-1}\right)$, matéria orgânica (0 e $\left.83 \mathrm{Mg} \mathrm{ha}^{-1}\right)$ e NiCh $\left(21\right.$ e $\left.42 \mathrm{~kg} \mathrm{ha}^{-1}\right)$. Médias de 3 repetições.

A fração óxidos teve uma maior participação na distribuição do Ni no NVdl do que no PVAd. A explicação mais plausível para esse fato é que os teores de óxidos no NVdL são em média três vezes maiores que no PVAd (Tabela 2). Tais resultados 
confirmam a importância dos óxidos na adsorção do $\mathrm{Ni}$, atuando no sentido de diminuir a proporção deste metal nas frações mais disponíveis (Uren, 1992; Wang et al., 1997 e Li $\&$ Shuman, 1996).

A extração da fração do $\mathrm{Ni}$ ligada a carbonatos foi realizada apenas nos tratamentos que apresentaram $\mathrm{pH}$ maior que 7,0, porém, esse metal não foi detectado nos extratos. Embora Mattigod \& Page (1983) tenham demonstraram que os carbonatos e bicarbonatos exercem um importante papel na distribuição do $\mathrm{Ni}$ em solos alcalinos, as condições impostas nos experimentos conduzidos podem não ter favorecido o estabelecimento de tais ligações.

No presente trabalho o metal foi adicionado ao solo na forma de $\mathrm{NiCh}_{2}$ e a alcalinização promovida através da adição de calcário, compostos esses que apresentam uma grande diferença de solubilidade. Como estes reagentes foram incorporados simultaneamente, uma rápida reação do $\mathrm{Ni}$ solubilizado com os componentes da fase sólida do solo pode não ter favorecido uma maior interação entre o metal e os íons carbonato. Existe ainda a possibilidade de que as doses de calcário não tenham sido elevadas o suficiente para fornecer espécies bicarbonato e carbonato para formar tais ligações.

Embora a extração da fração residual tenha sido realizada para toda as amostras, não foi detectado níquel nos referidos extratos. Isto sugere que quase todo metal adicionado foi retido nas frações mais disponíveis e por isso recuperado pelos extratores menos destrutivos.

Para explicar a ausência de metais na fração residual do procedimento de extração sequencial, alguns pontos devem ser destacados. Em primeiro lugar é importante notar que a forma com que o metal é adicionado ao solo exerce grande influencia sobre a sua disponibilidade. Candelária \& Chang (1997) estudaram a distribuição do Cd adicionado ao solo através de biossólido e de $\mathrm{Cd}\left(\mathrm{NO}_{3}\right)_{2}$, verificando que, no primeiro caso, a maior parte do metal ( 73 a $98 \%$ ) permaneceu no biossólido e apenas uma pequena quantidade passou para a solução e daí então para as fases sólidas do solo. Já o $\mathrm{Cd}$ adicionado na forma de sal solúvel teve a sua maior parte adsorvida pela fase sólida do solo. 
Provavelmente este comportamento não seja exclusivo do cádmio e também possa ser atribuído ao níquel.

Estando a maior parte do metal ligada aos compostos resistentes do biossólido, é possível que esta seja determinada apenas através da digestão da fração residual. Aliado a isso, muitos trabalhos com fracionamento utilizaram reativos pouco efetivos na extração dos metais de determinadas frações, fazendo com que estes sejam computados na fração residual.

\subsubsection{Resultados dos ensaios com adição biossólidos}

De maneira geral, tanto a natureza dos biossólidos como a dos solos tiveram efeito significativo sobre o teor de $\mathrm{Ni}$ em todas as frações, sendo que o primeiro fator foi o responsável pela maior parte das variações (Anexo1).

Devido a ampla variação de teores totais de Ni nos biossólidos, a discussão dos resultados será realizada basicamente em função da distribuição do metal nas diversas frações, a exemplo de outros trabalhos (McGrath \& Cegarra, 1992 e Bertoncini, 2002).

Em contaste com o fracionamento das amostras do ensaio com adição de $\mathrm{NiCh}$, o fracionamento das amostras que receberam os biossólidos, em ambos os solos, apresentaram grande parte do Ni na fração residual (Figura 11), semelhantemente ao comportamento descrito por McGrath \& Cegarra (1992); Gomes (1996), Wang, et al., (1997) e Pierrisnard (1996). De acordo com os princípios do fracionamento, o metal ligado a esta fração apresenta o mais alto grau de indisponibilidade.

A fração residual somente foi superada em importância pela fração óxidos, nos tratamentos que receberam os biossólidos provenientes das ETEs de Barueri e Suzano, nos dois solos. Estes materiais apresentam elevado $\mathrm{pH}$, pois passam por um tratamento terciário com adição de cal hidratada e cloreto férrico, que além de reduzir a carga patogênica, facilita a sua desidratação pela floculação da matéria orgânica. Além dos estudos com adição de $\mathrm{NiCh}_{2}$ apontarem que a adsorção do $\mathrm{Ni}$ pelos óxidos é favorecida pelo aumento do $\mathrm{pH}$, o fracionamento destes biossólidos demonstrou que uma grande proporção do metal já se encontrava ligada aos óxidos. 
Enquanto a fração matéria orgânica foi a terceira em importância, na maioria dos tratamentos, apresentando um teor relativamente constante nos diversos tratamentos aplicados aos solos, a fração trocável do $\mathrm{Ni}$ foi a que apresentou menores valores de concentração, praticamente desaparecendo com a adição dos biossólidos alcalinos.

A ligação do Ni com carbonatos não foi detectada nas amostras dos solos incubadas com os biossólidos, refletindo as baixas concentrações do metal com este tipo de ligação nos próprios materiais orgânicos (Figura 8). McGrath \& Cegarra (1992), incubaram amostras de solo com três biossólidos e realizaram o fracionamento tanto das amostras incubadas como dos materiais orgânicos aplicados. Os autores também verificaram que os teores de Ni ligado à fração carbonato no solo estavam relacionados aos teores determinados na mesma fração dos biossólidos.
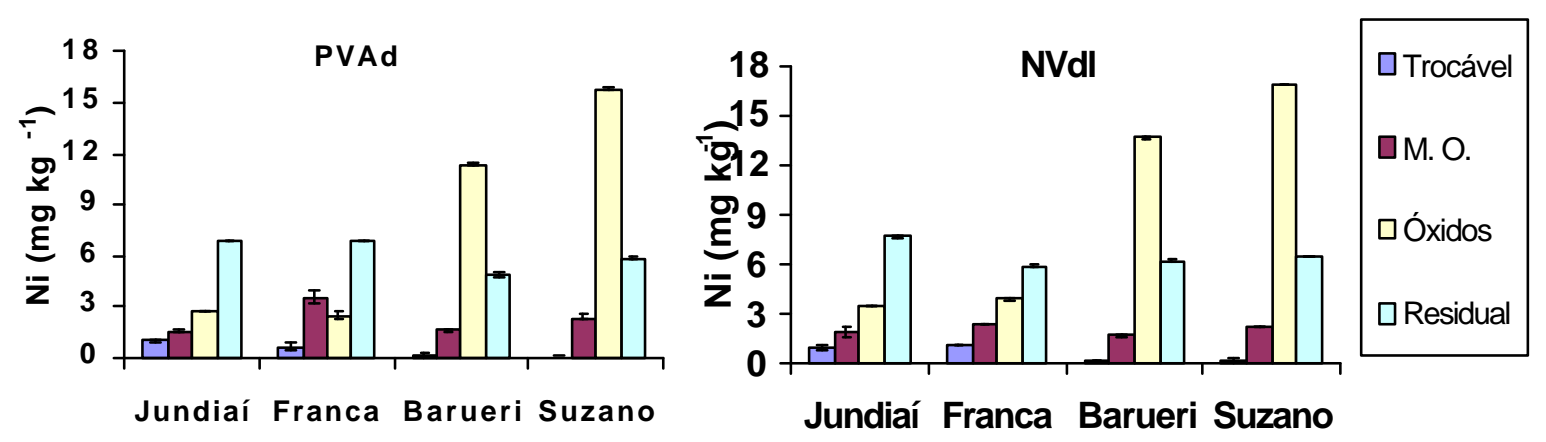

Figura 11 - Teores de níquel nas frações dos solos sob a aplicação de biossólidos de diferentes origens, médias de 3 repetições.

Tais observações reforçam a importância de se comparar a distribuição do metal nas frações do solo incubado com biossólidos, com a distribuição do mesmo metal nos próprios materiais orgânicos. É possível que, em alguns casos, o metal encontrado numa determinada fração do solo, já esteja nesta forma nos biossólidos, e assim permaneça caso o ambiente do solo não proporcione a quebra dessas ligações.

A maior parte das coincidências entre a distribuição do Ni nos tratamentos e nos biossólidos foi observada para os materiais não alcalinos, provenientes de Jundiaí e Franca. Já nos biossólidos alcalinos, de Barueri e Suzano, as formas mais disponíveis do 
metal observadas no fracionamento destes materiais (Figura 8), tenderam a passar para formas menos disponíveis nos solos (Figura 11), provavelmente sob efeito do aumento do $\mathrm{pH}$ dos tratamentos.

\subsubsection{Efeito dos fatores sobre as frações do $\mathrm{Ni}$ no estudo de $\mathrm{NiCl}_{2}$}

Os fatores "Dose de matéria orgânica", "Dose de níquel" e "Dose de calcário" aplicados nos solos apresentaram efeito significativo sobre o teor de $\mathrm{Ni}$ em todas as frações (Tabela 10), confirmando a importância destes fatores nos estudos de distribuição de metais nos solos.

As interações que se mostraram efetivas na variação dos teores de $\mathrm{Ni}$, nas diversas frações do solo, representaram sempre a ação de um fator em atenuar ou acentuar o efeito do outro, sem que houvesse inversão de comportamento. Desta forma, os efeitos principais foram discutidos, quando as interações foram estatisticamente significativas, mas pouco relevantes.

A análise de variância dos teores de $\mathrm{Ni}$ nas frações dos solos também apresentou baixos valores de soma de quadrados do resíduo, devido ao alto grau de precisão das medidas. Por este motivo, causas de variação cuja contribuição para a soma de quadrado total era baixa não foram consideradas relevantes.

Na fração trocável dos solos, todos os fatores e interações foram significativos ao nível de $1 \%$ de probabilidade. Porém, verifica-se que 94 e $97 \%$ das alterações na referida fração dos solos PVAd e NVdl, respectivamente, são explicadas apenas pelos efeitos isolados dos três fatores e pelo efeito da interação Ni x calcário (Tabela 10).

O efeito isolado do fator dose de calcário foi responsável por $48 \%$ das variações ocorridas no PVAd, e por 78\% no NVdl (Tabela 10). A redução dos teores tocáveis do Ni pelas doses crescentes do material corretivo (Figuras 9 e 10), se deve à tendência do metal em ser adsorvido por outras frações do solo, em resposta ao aumento do pH (Sauvé et al., 2000). Estas frações correspondem à matéria orgânica e aos óxidos do solo, que são mais abundantes no NVdl, explicando a maior importância do fator dose de calcário neste solo. 
$\mathrm{O}$ aumento da dose de $\mathrm{Ni}$ agiu no sentido de incrementar o teor trocável do metal (Figuras 9 e 10). Através dos valores de soma de quadrados, verifica-se que este fator contribuiu com $30 \%$ da variação dessa fração do PVAd, apresentando uma menor importância no NVdl, 9\% (Tabela 10). Provavelmente, a menor importância relativa da dose de Ni na fração trocável do NVdl se deva a maior tendência do metal para se localizar em frações menos disponíveis. Isso seria possível devido aos maiores teores de argila, óxidos e matéria orgânica do NVdl (Tabela 3).

Os fatores dose de calcário e dose de $\mathrm{Ni}$ apresentaram um efeito interativo, que contribuiu com 10 e 6\% das variações observada nos teores de Ni trocáveis dos solos PVAd e NVdl, respectivamente. Esta interação fez com que o aumento das doses de calcário promovesse reduções mais acentuadas do $\mathrm{Ni}$ trocável, na maior dose de $\mathrm{Ni}$ (Figuras 9 e 10).

Com a adição de uma fonte de matéria orgânica ao solo, esperava-se uma maior complexação do metal pela fração orgânica, e que com isso houvesse um decréscimo do Ni trocável. Porém, deve-se salientar que a matéria orgânica é uma das principais fontes de cargas de superfície, responsáveis pelas adsorções do metal extraído como trocável (Adriano, 1986).

Além disso, a adição da turfa resultou em redução do $\mathrm{pH}$ do solo, o que dificulta a formação dos complexos da matéria orgânica com o Ni. Sendo assim, a adição de matéria orgânica favoreceu o aumento do Ni na fração trocável, tanto por se opôr ao efeito do calcário em elevar o pH, como por aumentar a quantidade de sítios de troca catiônica do solo (Figuras 9 e 10).

Pode-se verificar que a adição de turfa ao NVdl, principalmente na maior dose de $\mathrm{Ni}$, resultou em maiores teores trocáveis e em teores similares do metal ligado à fração matéria orgânica (Figura 10), mesmo apresentando valores para $\mathrm{pH}$ do solo inferiores em quase uma unidade (Figura 5). É possível que sob valores de $\mathrm{pH}$ equivalentes, os tratamentos com adição da turfa retenham por complexação, teores de Ni superiores aos verificados nos tratamentos sem matéria orgânica.

$\mathrm{O} \mathrm{Ni}$ ligado à fração orgânica se comportou de forma inversamente proporcional àquela descrita para o metal na fração trocável, no que se refere aos efeitos do calcário e 
da matéria orgânica. Desta forma, os teores de Ni na fração matéria orgânica aumentaram com as doses de calcário e Ni e diminuíram com a adição de matéria orgânica. (Figuras 9 e 10).

Embora todas as causas de variação tenham apresentado significância estatística para a fração matéria orgânica do PVAd, a exemplo da fração anterior, a maior parcela das variações dos dados, 95\%, foi explicada pelos efeito isolados dos três fatores e pelas interações do calcário com os demais fatores. Ordenando as causas de variação por porcentagem da variação explicada obtém-se: dose de Ni, 33\% > dose de calcário, 27\% > dose de matéria orgânica $23 \%$ > interação dose de Ni x dose de calcário $7 \%$ > interação dose de matéria orgânica x dose de calcário 5\% (Tabela 10).

No NVdl, apenas os fatores dose de Ni e dose de calcário foram significativos, a $1 \%$ de probabilidade, explicando respectivamente, 88 e $8 \%$ da variação .

Tanto o aumento da dose de $\mathrm{Ni}$ como da dose de calcário resultaram em maiores teores de Ni na fração matéria orgânica. No primeiro caso, a maior quantidade de metal em contato com os compostos orgânicos do solo promoveu uma maior adsorção. Já no segundo caso, as elevações do pH aumentaram a capacidade de adsorção dos compostos orgânicos do solo (Uren, 1992 e McGrath, 1995).

Mesmo contribuindo para o aumento do teor de carbono no solo, a adição de matéria orgânica resultou em menores teores de Ni adsorvidos pela matéria orgânica, pelo fato de se opor às elevações de $\mathrm{pH}$ promovidas pelas doses de calcário.

Além dos efeitos isolados de cada fator, observaram-se significância estatística para interações no PVAd. Por meio destas, as doses de calcário e de matéria orgânica tiveram os seus efeitos acentuados na presença da maior dose de $\mathrm{Ni}$.

As variações observadas nos teores do N ligado aos óxidos do solo PVAd foram quase que exclusivamente explicadas pelos efeitos principais dos fatores aplicados. Os efeitos da dose de $\mathrm{Ni}$ e da dose de calcário, aumentando o teor do metal na fração, explicaram $84 \%$ das variações, enquanto o efeito da dose de matéria orgânica em diminuir o $\mathrm{Ni}$ na fração explicou $8 \%$. Não obstante os dois primeiros fatores tenham interagido no sentido de incrementar os teores de Ni ligados aos óxidos, a contribuição desta interação foi ínfima, comparada aos efeitos isolados dos fatores. 
Tabela 10. Resumo da análise de variância, contendo os valores de soma de quadrados e de probabilidade de significância pelo teste F, dos dados de Ni trocável, Ni ligado à matéria orgânica e Ni ligado aos óxidos, para os solos tratados com $\mathrm{NiCl}_{2}$, calcário e turfa.

\begin{tabular}{|c|c|c|c|c|c|c|c|c|c|c|c|c|c|}
\hline \multirow{3}{*}{$\begin{array}{l}\text { Causas de } \\
\text { Variação }\end{array}$} & \multirow[t]{3}{*}{ G.L } & \multicolumn{6}{|c|}{ 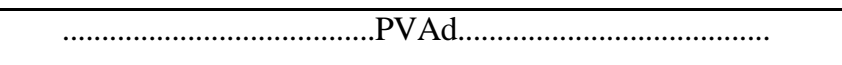 } & \multicolumn{6}{|c|}{ 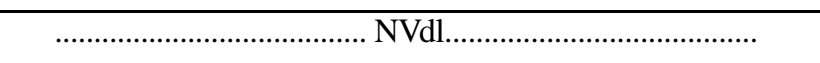 } \\
\hline & & \multicolumn{2}{|c|}{ Ni trocável } & \multicolumn{2}{|c|}{ Ni orgânico } & \multicolumn{2}{|c|}{ Ni óxidos } & \multicolumn{2}{|c|}{ Ni trocável } & \multicolumn{2}{|c|}{ Ni orgânico } & \multicolumn{2}{|c|}{$\mathrm{Ni}$ óxidos } \\
\hline & & S. Q. & $\operatorname{Pr}>|F|$ & S. Q. & $\operatorname{Pr}>|F|$ & S. Q. & $\operatorname{Pr}>|F|$ & S. Q. & $\operatorname{Pr}>|F|$ & S. Q. & $\operatorname{Pr}>|F|$ & S. Q. & $\operatorname{Pr}>|F|$ \\
\hline Dose de $\mathrm{MO}$ & 1 & 71,46 & 0,0001 & 313,6 & 0,0001 & 3,373 & 0,0001 & 15,79 & 0,0001 & 2,408 & 0,0134 & 36,00 & 0,0001 \\
\hline Dose de Ni & 1 & 381,9 & 0,0001 & 448,2 & 0,0001 & 25,94 & 0,0001 & 39,73 & 0,0001 & 371,6 & 0,0001 & 115,8 & 0,0001 \\
\hline Dose de Calcário & 2 & 620,9 & 0,0001 & 374,7 & 0,0001 & 8,219 & 0,0001 & 333,9 & 0,0001 & 33,08 & 0,0001 & 156,6 & 0,0001 \\
\hline $\mathrm{MO} * \mathrm{Ni}$ & 1 & 44,22 & 0,0001 & 19,82 & 0,0013 & 0,444 & 0,0190 & 0,277 & 0,0236 & 2,235 & 0,0167 & 8,960 & 0,0004 \\
\hline MO *Calcário & 2 & 20,10 & 0,0001 & 72,54 & 0,0001 & 0,038 & 0,7651 & 2,330 & 0,0001 & 0,516 & 0,4769 & 33,92 & 0,0001 \\
\hline Ni*Calcário & 2 & 129,46 & 0,0001 & 92,57 & 0,0001 & 0,797 & 0,0092 & 26,82 & 0,0001 & 0,711 & 0,3647 & 13,39 & 0,0002 \\
\hline MO*Ni*Calcário & 2 & 10,00 & 0,0001 & 17,79 & 0,0080 & 0,120 & 0,4300 & 9,812 & 0,0001 & 2,982 & 0,0233 & 8,957 & 0,0015 \\
\hline Resíduo & 24 & 6,685 & - & 35,87 & - & 1,682 & - & 1,138 & - & 8,103 & - & 12,42 & - \\
\hline Total & 35 & 1284,8 & - & 1375,1 & - & 40,62 & - & 429,8 & - & 421,7 & - & 386,0 & - \\
\hline
\end{tabular}


De acordo com a análise de variância dos dados do solo NVdl, os efeitos isolados dos fatores também explicam a maior parcela das variações dos dados de $\mathrm{Ni}$ da fração óxidos, $80 \%$. Contudo, o comportamento da referida fração nesse solo foi influenciado por todas as interações (Tabela 10). O efeito da dose de calcário no sentido de elevar a concentração do $\mathrm{Ni}$ na fração óxidos foi ampliado na maior dose de $\mathrm{Ni}$ e o efeito de ambos foi reduzido na presença da matéria orgânica (Figura 9).

\subsection{Níquel no extrato de saturação e especiação pelo Equilíbrio de Donnan}

Através da adição de $\mathrm{Ni}$ ao solo o metal entra em contato com as várias fases, capazes de interagir com ele. A especiação do Ni tratada neste item diz respeito ao metal em solução, mas para possibilitar uma melhor discussão dos resultados, é interessante considerar novamente os valores de $\mathrm{Ni}$ total determinado, decorrentes da aplicação de $\mathrm{NiCl}_{2}$ e dos biossólidos.

\subsubsection{Resultados dos ensaios com adição de $\mathrm{NiCl}_{2}$}

Os extratos de saturação das amostras, foram obtidos a partir de aproximadamente $1000 \mathrm{~g}$ solo incubado, que resultaram em volumes de aproximadamente $70 \mathrm{~mL}$ de solução. Com base nesses dados é possível transformar os teores de Ni solúvel determinado no extrato de saturação em termos de teor no solo.

Por exemplo, no tratamento que combinou a menor dose de $\mathrm{NiCh}$, sem adição de matéria orgânica e de calcário do PVAd (Tabela 11), 2,04 mg Ni L-1 no extrato de saturação corresponderiam a $0,143 \mathrm{mg} \mathrm{kg}^{-1}$ de $\mathrm{Ni}$ no solo. Comparando esse valor com o valor de $15,97 \mathrm{mg} \mathrm{kg}^{-1}$, obtido para o teor de $\mathrm{Ni}$ total determinado no solo, conclui-se que se extraiu apenas a centésima parte através do extrato de saturação. É importante observar que o tratamento exemplificado é o que reúne as condições mais favoráveis para a manutenção do Ni em solução.

Esse cálculo, embora aproximado, dá uma idéia de como a maior parte do níquel adicionado ao solo interage com a fase sólida do mesmo. A proporção do metal na 
solução é ainda muito menor quando são considerados os tratamentos sob aplicação de calcário e de matéria orgânica.

Somente com a adição de calcário, a solubilidade do metal foi reduzida de 14 a 18 vezes, resultando em teores solúveis cerca de 1500 vezes menores do que a concentração total.

Tabela 11. Valores de $\mathrm{pH}$ e teores Ni total no solo, solúvel e livre, sob diferentes doses de calcário $\left(0 ; 0,64\right.$ e 2,87 $\left.\mathrm{g} \mathrm{kg}^{-1}\right)$, matéria orgânica $\left(0\right.$ e $\left.64 \mathrm{~g} \mathrm{~kg}^{-1}\right)$ e $\mathrm{NiCh}$ (21 $42 \mathrm{~kg} \mathrm{ha}^{-1}$ ) no PVAd. Médias de 3 repetições

\begin{tabular}{|c|c|c|c|c|c|c|c|c|c|c|c|}
\hline & & \multicolumn{6}{|c|}{ MO 0} & \multicolumn{4}{|c|}{ MO 1} \\
\hline & & $\mathrm{pH}$ & $\begin{array}{c}\text { Total } \\
\mathrm{mg} \mathrm{kg}^{-1}\end{array}$ & $\begin{array}{c}\text { Solúvel } \\
\mathrm{mg} \mathrm{L}^{-1}\end{array}$ & $\begin{array}{c}\mathrm{Kd} \\
\mathrm{L} \mathrm{kg}^{-1}\end{array}$ & $\begin{array}{c}\text { Livre } \\
\mathrm{mg} \mathrm{L}^{-1}\end{array}$ & $\mathrm{pH}$ & $\begin{array}{c}\text { Total } \\
\mathrm{mg} \mathrm{kg}^{-1}\end{array}$ & $\begin{array}{c}\text { Solúvel } \\
\mathrm{mg} \mathrm{L}^{-1}\end{array}$ & $\begin{array}{c}\mathrm{Kd} \\
\mathrm{L} \mathrm{kg}^{-1} \\
\end{array}$ & $\begin{array}{l}\text { Livre } \\
\mathrm{mg} \mathrm{L}^{-1}\end{array}$ \\
\hline \multirow{3}{*}{$\bar{z}$} & $\mathrm{CO}$ & 4,56 & 15,97 & $2,04 \pm 0,03$ & 7,83 & $2,17 \pm 0,04$ & 4,38 & 15,76 & $0,50 \pm 0,02$ & 31,52 & $0,42 \pm 0,014$ \\
\hline & $\mathrm{C} 1$ & 5,62 & 15,10 & $0,97 \pm 0,01$ & 15,57 & $0,82 \pm 0,06$ & 4,90 & 15,14 & $0,35 \pm 0,01$ & 43,25 & $0,25 \pm 0,003$ \\
\hline & $\mathrm{C} 2$ & 7,13 & 14,79 & $0,15 \pm 0,03$ & 98,60 & $0,02 \pm 0,00$ & 5,83 & 15,01 & $0,15 \pm 0,01$ & 100,07 & $0,014 \pm 0,004$ \\
\hline \multirow{3}{*}{ ב̇ } & $\mathrm{CO}$ & 4,65 & 31,85 & $4,49 \pm 0,30$ & 7,09 & $5,68 \pm 0,62$ & 4,41 & 32,10 & $1,61 \pm 0,15$ & 19,93 & $1,41 \pm 0,156$ \\
\hline & C1 & 5,25 & 31,63 & $1,58 \pm 0,16$ & 20,02 & $1,37 \pm 0,31$ & 4,68 & 31,60 & $1,02 \pm 0,07$ & 30,98 & $0,67 \pm 0,065$ \\
\hline & $\mathrm{C} 2$ & 7,17 & 31,05 & $0,25 \pm 0,03$ & 124,2 & $0,03 \pm 0,01$ & 5,80 & 30,19 & $0,35 \pm 0,05$ & 89,26 & $0,066 \pm 0,002$ \\
\hline
\end{tabular}

A análise de variância revelou que os teores de Ni solúvel e de Ni livre do PVAd e do NVdl foram efetivamente influenciados por todos os fatores aplicados aos solos e em alguns casos, pelas interações entre estes (Tabela 13).

O efeito isolado das doses de calcário foi responsável pela maior parte das variações verificadas nos teores de Ni solúvel e livre, aproximadamente $40 \%$ em ambos os solos. Essas variações refletem a elevação do $\mathrm{pH}$ promovida pelo material corretivo. De acordo com Ma \& Lindsay (1995), o pH do sistema solo/água é o fator mais importante a influenciar a especiação e a concentração total de Ni.

Um outro parâmetro utilizado em estudos dessa natureza é o coeficiente de partição sólido-líquido, $\mathrm{Kd}$, o qual representa a relação entre a concentração total do contaminante na fase sólida do solo e a concentração encontrada na fase solução. A idéia 
da utilização do Kd é modelar os níveis de metal na solução, assumindo que esta relação é constante para o mesmo solo (Buchter et al., 1989). Alguns estudos, entretanto, têm demonstrado que os valores de $\mathrm{Kd}$ são dependentes das propriedades químicas do solo (Christensen et al., 1996 e Sauvé et al., 2000).

Os valores de $\mathrm{Kd}$, encontrados nos experimentos com adição de $\mathrm{NiCh}$, demonstraram alta correlação com os valores de $\mathrm{pH}$ dos solos $(0,86$ e 0,92 , para o PVAd e o NVdl, respectivamente). Esses resultados confirmam as observações de uma série de trabalhos que se referem ao $\mathrm{Kd}$ como sendo uma relação altamente influenciada pelo $\mathrm{pH}$ (Estados Unidos, 1996; Christensen et al., 1996 e Sauvé et al., 2000).

No PVAd, a adição de matéria orgânica também diminuiu a solubilidade de Ni. A simples presença da turfa no solo resultou em teores de Ni solúvel 300 a 400 vezes menores do que o teor total, o que também foi demonstrado pelo incremento nos valores de Kd. Estes resultados apontam para a redução da disponibilidade do metal devido à adição de meteria orgânica, o que concorda com os resultados obtidos por (Uren,1992 e Sauvé et al., 2000).

Observa-se nas Tabelas 11 e 12 que houve uma nítida diferença de magnitude entre os teores de $\mathrm{Ni}$ solúvel do PVAd e do $\mathrm{NVdl}$, com valores muito maiores no primeiro solo, principalmente nos tratamentos sem adição de matéria orgânica. Estes resultados podem ser bastante esclarecedores se confrontados aos da fração Ni trocável + solúvel, determinada pela extração sequencial.

Provavelmente, esse efeito da adição matéria orgânica se manifestou apenas no PVAd pelo fato deste conter uma pequena quantidade de sítios de adsorção eletrostática, devido aos reduzidos teores de argila, matéria orgânica e óxidos (Tabela 2). Isso demonstra que a matéria orgânica, mesmo acidificando o solo, pode atuar no sentido de reduzir a disponibilidade do $\mathrm{Ni}$, desde que haja uma deficiência de sítios para adsorção do metal no solo.

O NVdl que apresenta maiores teores de matéria orgânica, argila e óxidos, provavelmente não necessitou dos pontos de troca da turfa para adsorver eletrostaticamente o $\mathrm{Ni}$ solúvel. Dessa forma, o efeito preponderante da turfa foi determinado pela redução do $\mathrm{pH}$, que atuou no sentido de incrementar a fração trocável. 
Tabela 12. Valores de pH e teores Ni total no solo, solúvel e livre, sob diferentes doses de calcário $\left(0 ; 0,97\right.$ e 3,29 $\left.\mathrm{g} \mathrm{kg}^{-1}\right)$, matéria orgânica $\left(0\right.$ e $\left.71 \mathrm{~g} \mathrm{~kg}^{-1}\right)$ e $\mathrm{NiCh}(21$ $\left.42 \mathrm{~kg} \mathrm{ha}^{-1}\right)$. Médias de 3 repetições.

\begin{tabular}{|c|c|c|c|c|c|c|c|c|c|c|c|}
\hline & \multicolumn{6}{|c|}{ MO 0} & \multicolumn{4}{|c|}{ MO 1} \\
\hline & & $\mathrm{pH}$ & $\begin{array}{c}\text { Total } \\
\mathrm{mg} \mathrm{kg}^{-1}\end{array}$ & $\begin{array}{l}\text { Solúvel } \\
\mathrm{mg} \mathrm{L}^{-1}\end{array}$ & $\begin{array}{c}\mathrm{Kd} \\
\mathrm{L} \mathrm{kg}^{-1}\end{array}$ & $\begin{array}{l}\text { Livre } \\
\mathrm{mg} \mathrm{L}^{-1}\end{array}$ & $\mathrm{pH}$ & $\begin{array}{c}\text { Total } \\
\mathrm{mg} \mathrm{kg}^{-1}\end{array}$ & $\begin{array}{l}\text { Solúvel } \\
\mathrm{mg} \mathrm{L}^{-1}\end{array}$ & $\begin{array}{c}\mathrm{Kd} \\
\mathrm{L} \mathrm{kg}^{-1}\end{array}$ & $\begin{array}{l}\text { Livre } \\
\mathrm{mg} \mathrm{L}^{-1}\end{array}$ \\
\hline \multirow{3}{*}{$\dot{\bar{z}}$} & $\mathrm{CO}$ & 5,02 & 17,00 & $0,07 \pm 0,07$ & 242,8 & $0,03 \pm 0,003$ & 4,72 & 19,33 & $0,096 \pm 0,10$ & 201,4 & $0,081 \pm 0,008$ \\
\hline & $\mathrm{C} 1$ & 5,82 & 17,54 & $0,03 \pm 0,03$ & 584,7 & $<0,01$ & 5,15 & 19,24 & $0,065 \pm 0,07$ & 296,0 & $0,040 \pm 0,005$ \\
\hline & $\mathrm{C} 2$ & 6,97 & 16,67 & $0,02 \pm 0,02$ & 833,5 & $<0,01$ & 5,93 & 17,55 & $0,028 \pm 0,03$ & 626,8 & $<0,01$ \\
\hline \multirow{3}{*}{ ¿̇ } & $\mathrm{CO}$ & 5,00 & 34,43 & $0,40 \pm 0,36$ & 86,01 & $0,44 \pm 0,049$ & 4,73 & 33,72 & $0,422 \pm 0,42$ & 79,9 & $0,408 \pm 0,004$ \\
\hline & $\mathrm{C} 1$ & 5,73 & 33,50 & $0,08 \pm 0,08$ & 418,8 & $0,04 \pm 0,007$ & 5,03 & 34,68 & $0,221 \pm 0,22$ & 156,9 & $0,174 \pm 0,036$ \\
\hline & $\mathrm{C} 2$ & 6,87 & 34,06 & $0,03 \pm 0,03$ & 1135,3 & $<0,01$ & 5,90 & 35,52 & $0,060 \pm 0,06$ & 592,0 & $0,013 \pm 0,006$ \\
\hline
\end{tabular}

Quando se observa que os dois solos estudados apresentam teores similares de Ni na fração solúvel + trocável, obtida na extração seqüencial, isso pode encobrir que a mesma pode ser composta por diferentes proporções de níquel solúvel e níquel trocável.

A pequena fração de Ni que ocorre no extrato de saturação é que foi submetida ao procedimento de especiação baseada no Equilíbrio de Donnan, para que fosse distinguida a forma catiônica livre do metal das formas complexadas por diferentes ligantes. A importância desse procedimento se deve à idéia de que a forma catiônica livre é a mais relacionada a biodisponibilidade dos metais.

Pode-se dizer que a técnica do equilíbrio de Donnan se mostrou bastante eficiente para indicar o teor de níquel na forma catiônica livre no extrato de saturação e, por conseguinte, consiste numa ferramenta útil para se avaliar a biodisponibilidade do metal na solução do solo (Bigham et al., 1983; Bigham et al., 1984 e Kabata-Pendias \& Pendias, 1984).

Os teores de Ni livre apresentaram altos valores de correlação com os teores de Ni solúvel (0,99 no PVAd e 0,98, no NVdl). Embora esta correlação possa parecer 
óbvia, ela não é, pois soluções com teores iguais de metal solúvel podem apresentar diferentes concentrações de metal na forma livre, desde que as concentrações de ligantes adicionadas sejam diferentes.

Os teores de $\mathrm{Ni}$ na forma livre representaram a totalidade ou apenas uma fração ínfima do teor solúvel em ambos os solos. Porém a maior parte da variação do metal livre foi dependente daquela verificada para o metal solúvel (Tabelas 11 e 12).

Apenas nos maiores valores de $\mathrm{pH}$ promovido pelas doses de calcário, em que os teores solúveis já se apresentavam reduzidos, o teor livre resultou numa menor proporção de Ni solúvel. Esse comportamento pode ser explicado pelo fato do aumento do $\mathrm{pH}$ favorecer a formação de complexos solúveis entre o metal e a matéria orgânica nativa do solo (Uren, 1992).

No caso da aplicação de doses de matéria orgânica em ensaios de incubação uma provável explicação para a correlação entre os teores do níquel solúvel e livre seria que tanto a interação do metal com a matéria orgânica sólida, como a complexação do metal dissolvido pela matéria orgânica solúvel seriam fenômenos correlacionados a dose aplicada do material e assim relacionados entre si. Além disso, os dois conjuntos de dados correlacionados contêm teores de $\mathrm{Ni}$ provenientes de tratamentos com pouca ou nenhuma influência de agentes complexantes, os quais são mais altos e da mesma ordem de grandeza, nos dois parâmetros. Estes valores mais elevados prolongam a reta ajustada aos dados, contribuindo também para a obtenção dos altos valores de correlação. 
Tabela 13. Resumo da análise de variância, contendo os valores de soma de quadrados e de probabilidade de significância pelo teste F, dos dados de Ni solúvel, Ni livre e Ni nas plantas, para os solos tratados com $\mathrm{NiCh}$, calcário e turfa.

\begin{tabular}{|c|c|c|c|c|c|c|c|c|c|c|c|c|c|}
\hline \multirow{3}{*}{$\begin{array}{l}\text { Causas de } \\
\text { Variação }\end{array}$} & \multirow[t]{3}{*}{ G.L } & \multicolumn{6}{|c|}{. } & \multicolumn{6}{|c|}{ 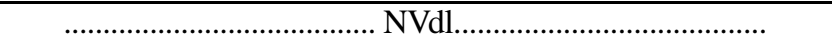 } \\
\hline & & \multicolumn{2}{|c|}{ Solúvel } & \multicolumn{2}{|c|}{ Livre } & \multicolumn{2}{|c|}{ Plantas } & \multicolumn{2}{|c|}{ Solúvel } & \multicolumn{2}{|c|}{ Livre } & \multicolumn{2}{|c|}{ Plantas } \\
\hline & & S. Q. & $\operatorname{Pr}>|F|$ & S. Q. & $\operatorname{Pr}>|F|$ & S. Q. & $\operatorname{Pr}>|F|$ & S. Q. & $\operatorname{Pr}>|F|$ & S. Q. & $\operatorname{Pr}>|F|$ & S. Q. & $\operatorname{Pr}>|F|$ \\
\hline Dose de MO & 1 & 7,498 & 0,0001 & 10,70 & 0,0001 & 37422,3 & 0,0001 & 0,0246 & 0,0001 & 0,0110 & 0,0001 & 18,45 & 0,1393 \\
\hline Dose de Ni & 1 & 6,648 & 0,0001 & 5,807 & 0,0001 & 18383,3 & 0,0001 & 0,1928 & 0,0001 & 0,2089 & 0,0001 & 757,08 & 0,0001 \\
\hline Dose de Calcário & 2 & 11.48 & 0,0001 & 15.14 & 0,0001 & 45106.2 & 0,0001 & 0,1260 & 0,0001 & 0,1794 & 0,0001 & 884.09 & 0,0001 \\
\hline $\mathrm{MO} * \mathrm{Ni}$ & 1 & 0,362 & 0,8990 & 0,880 & 0,9747 & 4758,9 & 0,0001 & 0,0032 & 0,0001 & 0,0002 & 0,4108 & 1,71 & 0,6455 \\
\hline MO *Calcário & 2 & 4.093 & 0,0001 & 5.780 & 0,0001 & 24764.3 & 0,0001 & 0,0036 & 0,0003 & 0,0066 & 0,0001 & 194.93 & 0,0001 \\
\hline $\mathrm{Ni}$ *Calcário & 2 & 2.093 & 0,0060 & 2.784 & 0,0001 & 7911.6 & 0,0001 & 0,0556 & 0,0001 & 0,1082 & 0,0001 & 196.61 & 0,0001 \\
\hline MO*Ni*Calcário & 2 & 0,492 & 0,1098 & 0.775 & 0,0880 & 3725.6 & 0,0001 & 0,0014 & 0,0247 & 0,0052 & 0,0001 & 62.10 & 0,0023 \\
\hline Resíduo & 24 & 0.012 & - & 0.044 & - & 164.69 & - & 0,0075 & - & 0,0003 & - & 7.8871 & - \\
\hline Total & 35 & - & - & - & - & - & - & - & - & - & - & - & - \\
\hline
\end{tabular}




\subsubsection{Resultados dos ensaios com adição de biossólidos}

De forma semelhante ao que observado nos experimentos com $\mathrm{NiCh}$, nota-se que os teores de $\mathrm{Ni}$ solúvel, provenientes da adição os biossólidos, são relativamente pequenos quando comparados ao teor total de $\mathrm{Ni}$ no solo (Tabela 14). Os valores de $\mathrm{Kd}$ refletem estas diferenças, apresentando maiores valores para os biossólidos com características alcalinas.

Os teores solúveis decorrentes da incorporação dos biossólidos de Barueri de Suzano podem parecer elevados para o $\mathrm{pH}$ que o solo atingiu (Tabela 7), mas deve-se lembrar que os teores totais de $\mathrm{Ni}$ adicionado eram bem maiores nestes casos.

Comparando-se os dois solos, observa-se menores valores de $\mathrm{Kd}$ para a aplicação de todos os biossólidos no PVAd, revelando a ocorrência de uma maior proporção do Ni solúvel em relação ao teor total do metal. Este comportamento foi mais evidente nos biossólidos provenientes de Barueri e de Suzano.

Tabela 14. Teores Ni total no solo, solúvel e livre, sob aplicação de diferentes biossólidos, médias de 3 repetições.

\begin{tabular}{|c|c|c|c|c|c|c|c|c|c|c|}
\hline \multirow[b]{2}{*}{ Biossólidos } & \multirow[b]{2}{*}{$\mathrm{pH}$} & \multicolumn{4}{|c|}{..PVAd... } & \multirow[b]{2}{*}{$\mathrm{pH}$} & \multirow[b]{2}{*}{$\begin{array}{c}\text { Total } \\
\mathrm{mg} \mathrm{kg}^{-1}\end{array}$} & \multicolumn{2}{|l|}{....NVdl.. } & \multirow[b]{2}{*}{$\begin{array}{c}\text { Livre } \\
\mathrm{mg} \mathrm{L}^{-1}\end{array}$} \\
\hline & & $\begin{array}{c}\text { Total } \\
\mathrm{mg} \mathrm{kg}^{-1}\end{array}$ & $\begin{array}{l}\text { Solúvel } \\
\mathrm{mg} \mathrm{L}^{-1}\end{array}$ & $\begin{array}{c}\mathrm{Kd} \\
\mathrm{L} \mathrm{kg}^{-1}\end{array}$ & $\begin{array}{l}\text { Livre } \\
\mathrm{mg} \mathrm{L}^{-1}\end{array}$ & & & $\begin{array}{l}\text { Solúvel } \\
\mathrm{mg} \mathrm{L}^{-1}\end{array}$ & $\begin{array}{c}\mathrm{Kd} \\
\mathrm{L} \mathrm{kg}^{-1}\end{array}$ & \\
\hline Jundiaí & 4,73 & 11,71 & $0,29 \pm 0,04$ & 40,38 & $0,16 \pm 0,05$ & 4,08 & 13,01 & $0,16 \pm 0,01$ & 81,31 & $0,11 \pm 0,02$ \\
\hline Franca & 5,04 & 12,10 & $0,15 \pm 0,02$ & 80,67 & $0,03 \pm 0,01$ & 4,58 & 13,44 & $0,15 \pm 0,02$ & 89,60 & $0,11 \pm 0,02$ \\
\hline Barueri & 8,24 & 18,41 & $0,28 \pm 0,04$ & 65,75 & $<0,01$ & 7,98 & 21,45 & $0,07 \pm 0,01$ & 306,40 & $<0,01$ \\
\hline Suzano & 7,86 & 25,35 & $0,17 \pm 0,02$ & 149,11 & $<0,01$ & 7,68 & 28,17 & $0,05 \pm 0,01$ & 563,40 & $<0,01$ \\
\hline
\end{tabular}

No item 4.3.1 já foi mencionado que os maiores teores de Ni solúvel no PVAd resultaram, provavelmente, da menor quantidade de sítios de adsorção de metais neste solo. No NVdl, entretanto, os maiores teores de argila, óxidos e matéria orgânica (Tabela 3), implicam numa maior adsorção do metal, sobretudo com o aumento de $\mathrm{pH}$ do solo, 
devido à adição dos biossólidos alcalinos (Theis \& Richter, 1979; Uren, 1992 e Ma \& Lindsay, 1995). .

E importante notar que os maiores teores de Ni solúvel do PVAd não se traduziram em maiores teores da forma catiônica livre desse metal (Tabela 14). Esse detalhe pode ser mais bem visualizado através dos coeficientes de correlação entre estas frações do metal, nos dois solos. Enquanto o coeficiente de correlação no NVdl foi igual a 0,98 , no PVAd este correspondeu a 0,52 , revelando um certo grau de desacordo entre os valores das frações.

Para que isso ocorresse, foi necessário que as condições do solo propiciassem uma combinação de teores relativamente altos de Ni solúvel, devido a menor adsorção do metal na fase sólida, e uma reduzida concentração de metal livre, pela presença de ligantes em solução.

A incorporação dos biossólidos de Barueri e Suzano resultou em valores muito baixos de concentração de Ni livre, em ambos os solos, sem que isso implicasse em teores também baixos de metal solúvel. Considerando os elevados valores de $\mathrm{pH}$ impostos aos solos pelos referidos biossólidos, essa situação sugere que a maior parte dos metais em solução encontravam-se na forma de complexos, protegidos tanto da adsorção pela fase sólida, como da precipitação pelo aumento do pH (Theis \& Richter, 1979).

\subsection{Absorção de Ni pelas plantas}

A alface é uma planta que acumula metais em suas folhas e serve bem como planta indicadora. Além disso, como a parte consumida corresponde às folhas, o uso de resíduos contendo metais na adubação dessa cultura, bem como de outras verduras folhosas, desperta preocupação. Normalmente as espécies hortícolas são cultivadas em solos com adição de grandes quantidades de matéria orgânica, sendo assim tentador para os produtores optarem pelo uso de biossólidos.

Cravo (1995) estudando a aplicação de composto de lixo em alface determinou a absorção de vários metais, inclusive do Ni. Os autores constataram que apesar do baixo 
teor de Ni nos compostos, as plantas de alface cultivadas sob aplicação do material aumentaram a concentração do metal.

\subsubsection{Resultados dos ensaios com adição de $\mathrm{NiCl}_{2}$}

Os maiores teores de $\mathrm{Ni}$ absorvidos pelas plantas foram observados nos dois solos para a maior dose do metal sem a adição de calcário nem de matéria orgânica. Apesar da nítida diferença de magnitude entre as concentrações observadas nos dois solos, o padrão de variação dos dados foi semelhante.

A adição de calcário afetou significativamente os teores de Ni nas plantas (Tabela 13), resultando numa menor absorção do metal devido ao aumento da dose do material corretivo, em ambos os solos (Tabela 15). Os valores de soma de quadrados das fontes de variação do Ni na planta confirmam que os aumentos de $\mathrm{pH}$, devido às doses de calcário, promoveram a maior parte das variações na absorção do metal (Tabela 13).

A matéria orgânica só se mostrou efetiva na variação dos teores de Ni nas plantas cultivadas no solo PVAd (Tabela 13), no qual também promoveu a redução dos referidos teores.

Embora cada solo correspondesse a um experimento específico, é possível destacar o expressivo efeito do solo na adsorção de $\mathrm{Ni}$ palas plantas de alface. $\mathrm{Na}$ ausência de aplicação de calcário e de matéria orgânica, a absorção pelas plantas foi aproximadamente de 8 vezes menor no NVdl que no PVAd, para as duas doses de $\mathrm{NiCl}$ (Tabela 15). Esse resultado se justifica pela maior capacidade do NVdl em adsorver o cátion $\mathrm{Ni}^{2+}$, devido dentre outros fatores, aos teores de óxidos, argila e matéria orgânica.

A adição de $\mathrm{NiCh}_{2}$ como fonte de níquel pode ser comparada à contaminação do solo por um resíduo inorgânico que contenha concentrações de sais de níquel, como aqueles provenientes de indústria de galvanoplastia.

Pôde-se verificar no item 4.3 que a matéria orgânica promoveu uma redução significativa nos teores de Ni solúvel no PVAd, ao contrário do que ocorreu no NVdl. Essa diferença de comportamento do metal solúvel entre os solos pode ser a causa da disparidade também observada na absorção de Ni pelas plantas, em função da adição 
turfa. Um forte indício da existência dessa relação, é a ocorrência de elevados coeficientes de correlação ( $R=0,98$ no PVAd e 0,84 no NVdl) entre os teores do metal solúvel e os determinados na planta (Anexos 2 e 3 ).

Os teores de Ni na planta também apresentaram altas correlações com a fração do metal que se encontrava na forma catiônica livre ( $\mathrm{R}=0,98$ no PVAd e 0,88 no NVdl). A atividade desta fração é citada como a melhor forma para se determinar a biodisponibilidade do metal (Bigham et al., 1983; Bigham et al., 1984 e Kabata-Pendias \& Pendias, 1984).

A concentração do teor solúvel pode incluir, em maior ou menor grau, espécies complexadas do metal que não seriam absorvidas pelas plantas e por isso ela pode ser criticada como um índice de biodisponibilidade

Em consequiência do exposto, no presente estudo, esperava-se que as correlações entre $\mathrm{Ni}^{+2}$ livre e $\mathrm{Ni}$ solúvel com o $\mathrm{Ni}$ absorvido pela planta apresentassem valores diferenciados.

Tabela 15. Teores Ni absorvidos pela alface nos solos PVAd e NVdl, sob doses de calcário $\left(0 ; 0,64\right.$ e $2,87 \mathrm{~g} \mathrm{~kg}^{-1}$ e $0 ; 0,97$ e $3,29 \mathrm{~g} \mathrm{~kg}^{-1}$, respectivamente), matéria orgânica $\left(0\right.$ e $\left.83 \mathrm{Mg} \mathrm{ha}^{-1}\right)$ e $\mathrm{NiCh}_{2}\left(21\right.$ e $\left.42 \mathrm{~kg} \mathrm{ha}^{-1}\right)$. Médias de 3 repetições.

\begin{tabular}{|c|c|c|c|c|c|}
\hline & & \multicolumn{2}{|c|}{ 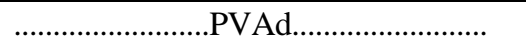 } & \multicolumn{2}{|c|}{ 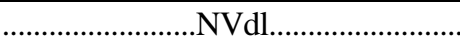 } \\
\hline & & MO 0 & MO 1 & MO 0 & MO 1 \\
\hline \multirow{4}{*}{$\stackrel{\vdots}{i}$} & & $\mathrm{mg} \mathrm{kg}^{-1}$ & $\mathrm{mg} \mathrm{kg}^{-1}$ & $\mathrm{mg} \mathrm{kg}^{-1}$ & $\mathrm{mg} \mathrm{kg}^{-1}$ \\
\hline & $\mathrm{CO}$ & $129,50 \pm 24,21$ & $25,47 \pm 0,99$ & $16,21 \pm 1,41$ & $11,39 \pm 1,78$ \\
\hline & $\mathrm{C} 1$ & $42,29 \pm 2,73$ & $17,04 \pm 1,47$ & $9,32 \pm 0,57$ & $7,36 \pm 1,58$ \\
\hline & $\mathrm{C} 2$ & $5,25 \pm 0,64$ & $10,07 \pm 1,41$ & $2,86 \pm 0,89$ & $6,66 \pm 0,93$ \\
\hline \multirow{3}{*}{$\begin{array}{c}\vdots \\
\stackrel{\vdots}{i} \\
z \\
\vdots\end{array}$} & $\mathrm{CO}$ & $298,43 \pm 33,17$ & $64,89 \pm 5,04$ & $40,00 \pm 8,29$ & $23,96 \pm 3,06$ \\
\hline & $\mathrm{C} 1$ & $73,57 \pm 15,29$ & $40,50 \pm 3,66$ & $13,18 \pm 1,45$ & $17,14 \pm 1,79$ \\
\hline & $\mathrm{C} 2$ & $11,79 \pm 1,30$ & $13,79 \pm 1,66$ & $4,04 \pm 0,70$ & $10,50 \pm 1,06$ \\
\hline
\end{tabular}

$\mathrm{C}=$ calcário; $\mathrm{MO}=$ matéria orgânica

Como foi discutido no item 4.3, tratamentos com pouca ou nenhuma influência de ligantes na solução certamente influenciaram a obtenção de uma correlação quase perfeita entre os teores de Ni solúvel e livre. Conseqüentemente, isso explica a obtenção de alta correlações entre os teores de Ni solúvel e os absorvidos pelas plantas. 
A citada correlação provavelmente seria reduzida por tratamentos que resultassem em teores elevados e variáveis de níquel solúvel, mas que pela presença de ligantes com alta afinidade pelo metal, determinassem baixos teores de $\mathrm{Ni}^{+2}$ livre.

\subsubsection{Resultados dos ensaios com adição de biossólidos}

A absorção de Ni pelas plantas, no ensaio com aplicação de biossólidos, foi muito menor do que a observada nos experimentos com adição de $\mathrm{NiCh}$, mesmo para teores comparáveis de $\mathrm{Ni}$ total. Estes resultados confirmam que as observações de outros trabalhos desta natureza, que relatam a menor biodisponibilidade do metal adicionado através de biossólidos, em relação à adição de sal solúvel (Bigham et al., 1983 e Hinesley et al., 1982).

Tabela 16. Teores Ni absorvidos pelas plantas de alface cultivadas após a aplicação de diferentes biossólidos, no PVAd e no NVdl, médias de 3 repetições.

\begin{tabular}{|c|c|c|c|c|}
\hline Biossólidos & Jundiaí & Franca & Barueri & Suzano \\
\hline & \multicolumn{4}{|c|}{ 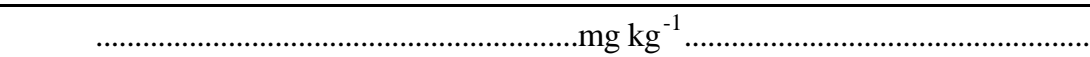 } \\
\hline PVAd & $4,47 \pm 0.03$ & $2,32 \pm 0.11$ & $1,49 \pm 0.17$ & $1,17 \pm 0.12$ \\
\hline NVdl & $4,03 \pm 0.46$ & $2,55 \pm 0.21$ & $0,92 \pm 0.15$ & $1,02 \pm 0.08$ \\
\hline
\end{tabular}

Os resultados das correlações entre os teores de Ni na planta e os teores solúvel e livre do metal (Anexos 4 e 5) apresentaram indícios de que a última fração é um indicador mais eficiente da biodisponibilidade do metal.

$\mathrm{O} \mathrm{Ni}$ absorvido pelas plantas no NVdl apresentou altas correlações tanto com os teores solúveis como com os livres do metal ( $\mathrm{R}=0,91$ e 0,90, respectivamente). Contudo, observou-se no PVAd que a absorção do metal pelas plantas se correlacionou satisfatoriamente apenas com o Ni livre $(R=0,95)$, em contraste com o teor solúvel, que resultou num coeficiente de correlação igual a 0,48 . 
Os resultados apresentados são coerentes com o que foi discutido no item 4.3.2, acerca da falta de correspondência entre a concentração do Ni total na solução e a fração do metal livre.
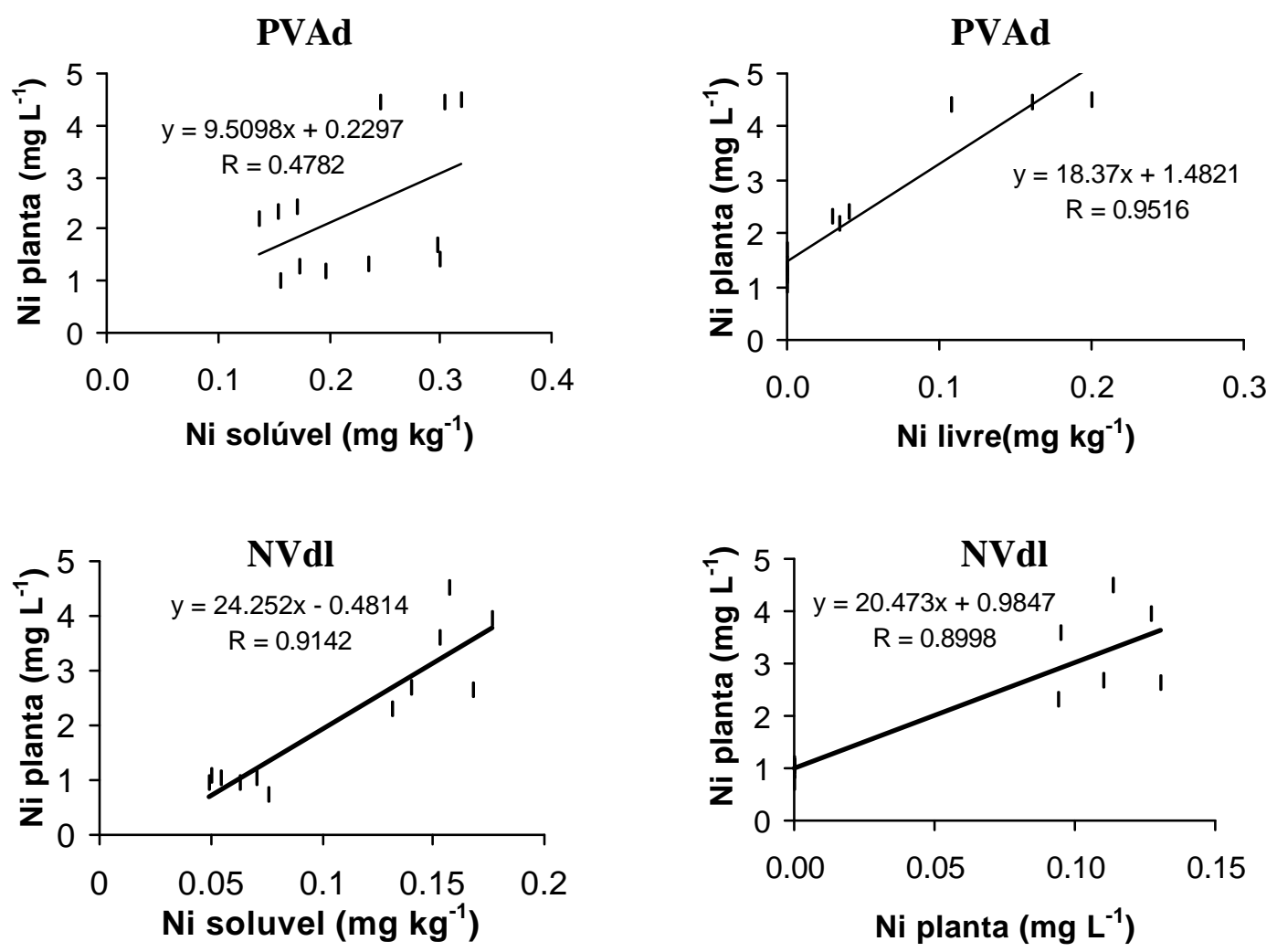

Figura 12 - Correlações dos teores de $\mathrm{Ni}$ solúvel e livre com os teores do metal absorvidos pelas plantas nos solos tratados com biossólidos.

Vale frisar que tanto nos experimentos com adição de $\mathrm{NiCl}$ como no que adicionou o $\mathrm{Ni}$ através de biossólidos, os teores de $\mathrm{Ni}$ solúvel foram maiores no solo PVAd. Contudo, nos primeiros casos, os mesmos fatores que diminuíam os teores de $\mathrm{Ni}$ solúvel, devido o aumento da adsorção, atuavam na redução da proporção do metal livre, por formação de complexos solúveis. Isso fez com que as duas frações do Ni tivessem o mesmo padrão de variação e não diferissem na relação com o Ni absorvido pelas plantas. 
Com a adição de biossólidos aos solos, possivelmente houve uma maior introdução de ligantes, principalmente orgânicos, que formaram complexos solúveis com o Ni. Este processo compete com a adsorção do metal na fase sólida e com a sua absorção pelas plantas (Theis \& Richter, 1979).

A ocorrência de um alto teor do metal solúvel, aliado a uma reduzida proporção deste na forma iônica livre, caracteriza a formação de complexos solúveis, que não são disponíveis às plantas. Por este motivo, o metal livre é um melhor indicador da biodisponibilidade do metal (Binghan, 1983).

\subsection{Modelagem das diferentes formas de Ni no solo}

Um dos objetivos do presente estudo era obter um modelo matemático que pudesse ser usado para predizer o comportamento do níquel no solo em função da aplicação de biossólidos. Para tanto, a aplicação de $\mathrm{NiCh}_{2}$ como fonte de níquel, calcário e turfa nos ensaios fatoriais visava causar nos atributos dos solos variações comparáveis àquelas provocadas pela aplicação de diferences tipos de biossólidos.

A escolha da fonte de matéria orgânica foi problemática pela dificuldade em se selecionar um material que pudesse representar exatamente a natureza dos compostos orgânicos dos biossólidos. A opção pela turfa baseou-se nas suas características de estabilidade, ausência de metais pesados e capacidade de interação com metais.

Pelos resultados de análise química de solo dos ensaios, discutidos anteriormente, nota-se que esse objetivo foi atingido. Grosso modo, nos ensaios com aplicação de $\mathrm{NiCh}$, os teores de carbono orgânico do solo variaram entre 5 e $18 \mathrm{mg} \mathrm{kg}^{-1}$; o pH em água entre 4,5 e 7,0 e o teor de Ni total entre 16 e $33 \mathrm{mg} \mathrm{kg}^{-1}$. Nos ensaios com aplicação de biossólidos o pH variou entre 4,7 e 8,2; o teor de carbono orgânico entre 9,8 e 18 e o níquel total entre 11,7 e 28 As variações obtidas são de suma importância, visto que são fatores que efetivamente influenciam o comportamento do $\mathrm{Ni}$ no solo. Em outras palavras, têm uma relação de causa e efeito com as frações do metal, e por isso podem ser usadas como variáveis independentes do comportamento destas frações. 


\subsubsection{Obtenção das equações de regressão}

Optou-se por utilizar um modelo de regressão múltipla para descrever o comportamento das diferentes frações do $\mathrm{Ni}$ obtidas no estudo de extração seqüencial e ainda dos teores de $\mathrm{Ni}$ solúvel e de $\mathrm{Ni}^{+2}$ livre, obtidos nos extratos de saturação. São assim incluídas todas as causas de variações controladas possíveis, pois são consideradas as variáveis independentes de forma isolada e interativa.

O modelo é o seguinte:

$[N i]_{i}=a+b X+c Y+d Z+e X Y+f X Z+g Y Z+h X Y Z$

Onde: $a, b, c, d, e, f, g$ e $h=$ parâmetros estimados

$[\mathrm{Ni}]_{\mathrm{i}}=$ concentração de Ni no compartimento $\mathrm{i}$

$X=$ Teor de Carbono orgânico

$Y=$ Teor de Ni total

$Z=$ Valor de $\mathrm{pH}$

É importante destacar também que os atributos dos solos, utilizados na regressão como variáveis independentes, são facilmente determinados através de análises de rotina. Comprovando-se a validade do modelo proposto, para um determinado solo, seria possível prever o comportamento do Ni nas suas frações sem a necessidade de realização de procedimentos que despedem mais tempo e recursos como a extração seqüencial. Tal ferramenta pode vir a se útil no monitoramento de áreas contaminadas por metais o/ou que recebem aplicação de materiais orgânicos que contêm metais, como biossólidos.

O modelo proposto se mostrou eficiente no ajuste dos dados de concentração das frações do Ni na fase sólida de ambos os solos, com $\mathrm{R}^{2}$ variando de 0,89 a 0 ,97. Já para os teores do metal em solução, tanto solúveis como livres, o modelo apresentou valores de $\mathrm{R}^{2}$ variando entre 0,78 a 0,86 (Tabela 17 e 18 ). 
Com base na significância dos parâmetros estimados das equações, é possível identificar as variáveis independentes que têm maiores possibilidades de explicar o comportamento do metal em cada fração.

Em ambos os solos, a maior parte dos parâmetros estimados na equação de regressão dos teores de Ni trocável apresentou alto nível de significância (Tabelas 17 e 18). Dentre os parâmetros relacionados com as variáveis independentes, o do $\mathrm{pH}$ foi a que apresentou menor probabilidade de explicar as variações dos dados de concentração do metal na fração trocável, em ambos os solos.

Mesmo que se considere o efeito isolado do $\mathrm{pH}$ incapaz de explicar as variações ocorridas no Ni trocável, as interações desse com as demais variáveis independentes da equação desempenharam esse papel, Sendo assim, optou-se por não desconsiderar nenhum dos parâmetros, uma vez que estes podem vir a ser decisivos na previsão do metal na fração.

No NVdl, as interações "matéria orgânica x Ni" e a tripla apresentaram probabilidades de significância em torno de 93 e 90\%, respectivamente. Tais valores de probabilidade indicam que os parâmetros a que se referem têm grande chance de diferirem de zero, apesar de serem inferiores a $95 \%$, que é normalmente considerado o limite mínimo de probabilidade admitida.

Os dados de Ni ligado à fração orgânica no PVAd se ajustaram bem ao modelo, com $\mathrm{R}^{2}$ de $91 \%$. Porém, todos os parâmetros estimados apresentaram valores baixos de probabilidade de serem significantes (Tabela 17). No NVdl no entanto, além de um maior coeficiente de determinação, apenas um parâmetro estimado se apresenta com baixa probabilidade de significância, aquele relacionado à dose de Ni (Tabela 18).

Embora a maioria dos parâmetros estimados para fração óxidos tenha apresentado sinais concordantes nos dois solos, apenas os parâmetros relacionados ao pH e à interação "Ni x pH” apresentaram significâncias semelhantes (Tabelas 17 e 18).

Pelo fato do modelo utilizado na equação de regressão ser relativamente simples, os parâmetros não significativos não serão desconsiderados. 
Tabela 17. Valores dos parâmetros estimados para a regressão múltipla, ajustada às frações do Ni na fase sólida e na solução no

PVAd tratado com $\mathrm{NiCl}_{2}$, e suas respectivas probabilidades de significância.

\begin{tabular}{|c|c|c|c|c|c|c|c|c|c|c|c|c|}
\hline \multirow{2}{*}{$\begin{array}{l}\text { Parâmetros } \\
\text { estimados }\end{array}$} & \multicolumn{2}{|c|}{ Ni Trocável } & \multicolumn{2}{|c|}{ Ni na Mat. Orgânica } & \multicolumn{2}{|c|}{ Ni nos Óxidos } & \multicolumn{2}{|c|}{ Ni solúvel } & \multicolumn{2}{|c|}{ Ni livre } & \multicolumn{2}{|c|}{ Ni nas plantas } \\
\hline & valor & Prob $>|\mathrm{T}|$ & valor & valor & $\operatorname{Prob}>|\mathrm{T}|$ & valor & valor & Prob $>|\mathrm{T}|$ & valor & valor & Prob $>|\mathrm{T}|$ & valor \\
\hline $\bar{a}$ & 5,59 & 0,4417 & $-6,40$ & 0,5995 & $\overline{0,41}$ & 0,7845 & 0,714 & 0,8167 & 0,226 & 0,9559 & $-9,545$ & 0,9705 \\
\hline $\mathrm{b}$ & $-1,83$ & 0,0132 & 1,20 & 0,3091 & $-0,29$ & 0,0515 & $-0,139$ & 0,6385 & $-0,093$ & 0,8119 & $-1,663$ & 0,9464 \\
\hline $\mathrm{c}$ & 0,84 & 0,0064 & $-0,147$ & 0,7628 & $-0,016$ & 0,7877 & 0,367 & 0,0055 & 0,434 & 0,0119 & 26,631 & 0,0143 \\
\hline $\mathrm{d}$ & $-0,92$ & 0,4630 & 1,88 & 0,3739 & $-0,24$ & 0,3555 & $-0,093$ & 0,8631 & $-0,027$ & 0,9700 & 1,119 & 0,9802 \\
\hline $\mathrm{e}$ & 0,117 & 0,0002 & $-0,040$ & 0,4006 & 0,006 & 0,3153 & $-0,009$ & 0,4431 & $-0,014$ & 0,3839 & $-1,117$ & 0,2680 \\
\hline $\mathrm{f}$ & 0,314 & 0,0214 & $-0,250$ & 0,2588 & 0,059 & 0,0351 & 0,022 & 0,6905 & 0,016 & 0,8334 & 0,3789 & 0,9358 \\
\hline g & $-0,101$ & 0,0516 & 0,123 & 0,1533 & 0,026 & 0,0185 & $-0,050$ & 0,0263 & $-0,061$ & 0,0411 & $-3,736$ & 0,0469 \\
\hline $\mathrm{h}$ & $-0,021$ & 0,0003 & 0,006 & 0,4609 & 0,001 & 0,2062 & 0,001 & 0,6801 & 0,002 & 0,6020 & 0,146 & 0,4492 \\
\hline $\mathrm{R}^{2}$ & 0,97 & - & 0,91 & - & 0,96 & - & 0,8167 & - & 0,8138 & - & 0,7802 & - \\
\hline
\end{tabular}


Tabela 18. Valores dos parâmetros estimados para a regressão múltipla, ajustada às frações do Ni na fase sólida e na solução no

$\mathrm{NVdl}$ tratado com $\mathrm{NiCh}$, e suas respectivas probabilidades de significância.

\begin{tabular}{|c|c|c|c|c|c|c|c|c|c|c|c|c|}
\hline \multirow{2}{*}{$\begin{array}{l}\text { Parâmetros } \\
\text { estimados }\end{array}$} & \multicolumn{2}{|c|}{ Ni Trocável } & \multicolumn{2}{|c|}{ Ni na Mat. Orgânica } & \multicolumn{2}{|c|}{ Ni nos Óxidos } & \multicolumn{2}{|c|}{ Ni solúvel } & \multicolumn{2}{|c|}{ Ni livre } & \multicolumn{2}{|c|}{ Ni nas plantas } \\
\hline & valor & Prob $>|\mathrm{T}|$ & valor & valor & Prob $>|\mathrm{T}|$ & valor & valor & Prob $>|\mathrm{T}|$ & valor & valor & Prob $>|\mathrm{T}|$ & valor \\
\hline$a$ & $-18,77$ & 0,1787 & 22,89 & 0,0341 & 8,42 & 0,4486 & $-0,395$ & 0,5082 & $-1,109$ & 0,1633 & $-20,715$ & 0,6647 \\
\hline$b$ & 2,46 & 0,0374 & $-2,77$ & 0,0030 & $-1,09$ & 0,2252 & $-0,048$ & 0,3440 & $-0,011$ & 0,8687 & $-0,736$ & 0,8547 \\
\hline$c$ & 1,70 & 0,0023 & $-0,59$ & 0,1341 & $-1,15$ & 0,0033 & 0,033 & 0,1397 & 0,066 & 0,0285 & 5,224 & 0,0058 \\
\hline d & 3,53 & 0,1428 & $-3,61$ & 0,0504 & $-1,64$ & 0,3707 & 0,045 & $0,66,7$ & 0,150 & 0,2699 & 3,416 & 0,6779 \\
\hline$e$ & $-0,079$ & 0,0668 & 0,092 & 0,0064 & 0,073 & 0,0231 & 0,003 & 0,1319 & 0,001 & 0,6033 & $-0,113$ & 0,4457 \\
\hline$f$ & $-0,44$ & 0,0411 & 0,48 & 0,0044 & 0,22 & 0,1602 & 0,009 & 0,3064 & 0,004 & 0,7394 & 0,157 & 0,8287 \\
\hline$g$ & $-0,26$ & 0,0054 & 0,16 & 0,0215 & 0,26 & 0,0002 & 0,004 & 0,3104 & $-0,009$ & 0,0847 & $-0,764$ & 0,0176 \\
\hline$h$ & 0,013 & 0,0965 & $-0,016$ & 0,0094 & $-0,014$ & 0,0130 & 0,001 & 0,1005 & $-0,0003$ & 0,4331 & 0,014 & 0,5918 \\
\hline $\mathrm{R}^{2}$ & 0,89 & - & 0,94 & - & 0,95 & - & 0,8620 & - & 0,8203 & - & 0,8480 & - \\
\hline
\end{tabular}




\subsubsection{Previsão das formas de Ni nos solos tratados com biossólidos pelas equações de regressão obtidas nos experimentos com adição de $\mathrm{NiCl}_{2}$, calcário e turfa}

As equações de regressão, obtidas nos experimentos com adição de $\mathrm{NiCh}$, calcário e turfa descrevem o comportamento do $\mathrm{Ni}$ em cada fração dos solos com base nas variações dos teores de carbono orgânico, $\mathrm{Ni}$ total e valores de pH. Estas equações foram utilizadas na tentativa de se estimar dos teores de $\mathrm{Ni}$ nas frações do experimento com adição biossólidos, com base nas variáveis independentes obtidas neste.

De maneira geral, os teores de Ni estimados para as diversas formas do metal não apresentaram correspondência com os teores determinados. Os melhores resultados foram obtidos para a fração do metal ligada a óxidos, nos dois solos (Figura 12), e para os teores de Ni solúvel, resultante da aplicação de dois biossólidos, em apenas um solo (Figura 13).

No primeiro caso, obteve-se uma boa correlação entre os teores determinados e os teores calculados pela equação, sem que houvesse correspondência entre os valores destes. Isso demonstra que o modelo foi eficiente em prever tendência de variação dos teores de Ni na fração, em função das mudanças nos teores de $\mathrm{C}$ orgânico, dos teores totais do metal e dos valores de $\mathrm{pH}$ (Figura 12).
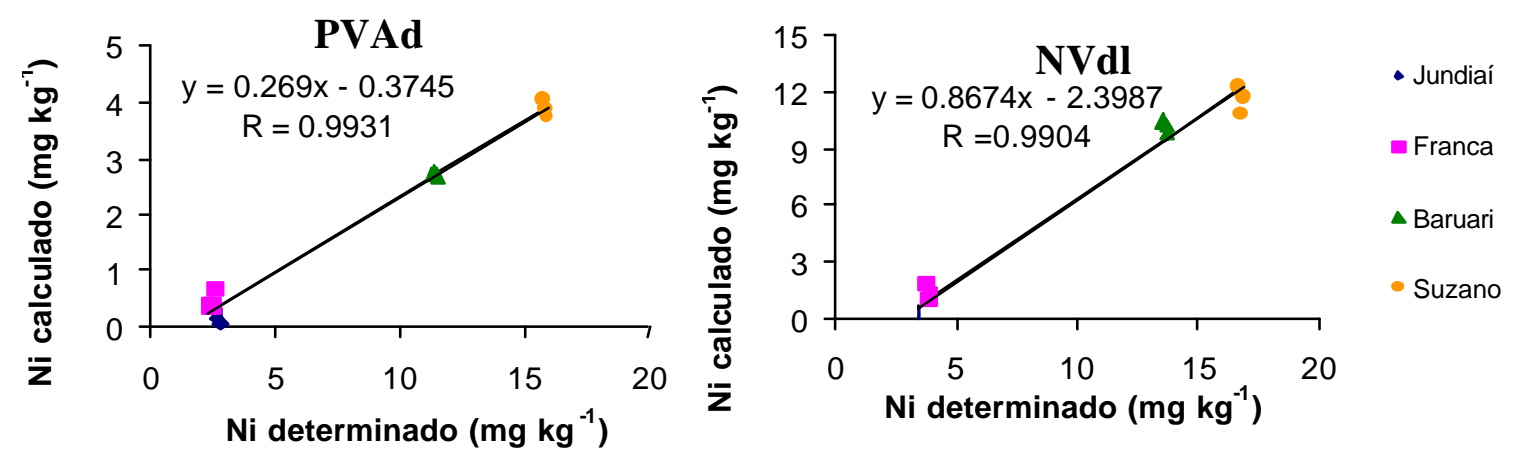

Figura 12.Correlação entre os teores de Ni determinados na fração óxido dos tratamentos com biossólidos e os calculados, para os mesmos tratamentos, utilizando a equação obtida a partir dos dados dos experimentos com adição de $\mathrm{NICl}_{2}$. 
Já na previsão dos teores solúveis de $\mathrm{Ni}$, embora não tenha sido verificada correlação alguma entre os valores determinados e calculados da variável, estes foram de mesma ordem de grandeza para os tratamentos com adição dos biossólidos de Jundiaí e Suzano no PVAd. Isso ocorreu especificamente para esses biossólidos e para o citado solo por causa da combinação dos fatores: menor $\mathrm{pH}$ do biossólido e menor capacidade de retenção de metal pelo solo, que favoreceram maior concentração do $\mathrm{Ni}$ na forma solúvel, o que foi típico do ensaio de adição de $\mathrm{NiCh}_{2}$.

A concordância entre os sentidos das alterações dos valores estimados e determinados levam a crer que as alterações promovidas pelas variáveis independentes nos experimentos com adição de $\mathrm{NiCh}$, tiveram o mesmo sentido das verificadas nos tratamentos com biossólidos, com exceção do carbono orgânico, que nos biossólidos não deve estar correlacionado ao $\mathrm{pH}$.

A incapacidade das equações obtidas nos experimentos com adição de $\mathrm{NiCl}_{2} \mathrm{em}$ predizer o comportamento do $\mathrm{Ni}$ adicionado ao solo através de biossólidos, se deve a uma série de fatores que contribuíram para que as condições experimentais fossem diferentes entres os experimentos com adição de $\mathrm{NiCh}$ e os com adição de biossólidos.

Um fator de grande relevância na diferenciação das condições experimentais entre os experimentos foi a forma do metal adicionada. A utilização de um sal solúvel não representou satisfatoriamente o metal adicionado através de biossólidos. Enquanto a maior deste último já chega ao solo ligado aos componentes do material orgânico, e em muitos casos assim permanecem (Candelária \& Chang, 1997), o metal proveniente de uma fonte solúvel necessita de uma considerável quantidade de tempo para que se ligue às partículas do solo (Manceau \& Calas 1986 e Bruemmer et al., 1988).

Outra diferença a ser considerada diz respeito à qualidade da matéria orgânica adicionada. Embora a turfa tenha sido escolhida por ser um material bastante rico em matéria orgânica, com elevado grau de estabilização, é importante destacar que os próprios biossólidos apresentam diferenças entre si, tanto quanto a composição como ao grau de estabilização da matéria orgânica. Isto dificulta o estabelecimento de um padrão de comportamento de um determinado metal, em função do teor de carbono orgânico, 
levando-se em conta apenas uma fonte deste elemento. A utilização da turfa resultou numa diferenciação adicional, pois promoveu uma acidificação dos tratamentos.

A importância do estudo realizado nos experimentos com adição de $\mathrm{NiCh}$, turfa e calcário não é diminuída pelo fato das equações obtida neste não preverem o comportamento do $\mathrm{Ni}$ adicionado através de biossólidos. As informações geradas neste estudo se referem efetivamente ao comportamento do $\mathrm{Ni}$, quando este está disponível para interagir com os diversos componentes do solo. A utilidade desses modelos pode estar reservada à previsão do comportamento do $\mathrm{Ni}$ em áreas contaminadas por fontes solúveis do metal. 


\section{CONCLUSÕES}

Dentro das condições em que foi conduzido o presente estudo, as seguintes conclusões podem ser inferidas:

A variação de $\mathrm{pH}$ foi o fator que mais afetou a concentração de níquel nas frações definidas pelo esquema de extração seqüencial adotado;

$\mathrm{O}$ níquel adicionado através do sal $\mathrm{NiCh}_{2}$ interagiu acentuadamente com os componentes do solo, predominando em diferentes frações, exceto na fração residual, em função dos tratamentos aplicados;

O níquel aplicado via biossólido se localizou preponderantemente nas frações com maior energia de retenção: frações óxido e residual;

A distribuição do níquel adicionado aos solos através de biossólidos apresenta semelhanças com a distribuição do metal nos biossólidos;

O teor de níquel na forma catiônica livre, determinado com base na teoria do Equilíbrio de Donnan, foi o melhor indicador de biodisponibilidade. 


\section{ANEXOS}


Anexo 1. Resumo da análise de variância, contendo os valores da somas dos quadrados (SQ) e de probabilidade de significância pelo teste $\mathrm{F}(\mathrm{Pr}>|\mathrm{F}|)$, dos dados de carbono orgânico, níquel total, $\mathrm{pH}$, Ni trocável, Ni ligado à matéria orgânica e Ni ligado aos óxidos, para os solos tratados com biossólidos.

\begin{tabular}{|c|c|c|c|c|c|c|c|c|c|c|c|c|c|}
\hline \multirow{2}{*}{ Causas de variação } & \multirow{2}{*}{ G.L } & \multicolumn{2}{|c|}{ C orgânico } & \multicolumn{2}{|c|}{ Ni total } & \multicolumn{2}{|c|}{$\mathrm{pH}$} & \multicolumn{2}{|c|}{ Ni trocável } & \multicolumn{2}{|c|}{ Ni orgânico } & \multicolumn{2}{|c|}{ Ni óxidos } \\
\hline & & S. Q. & $\operatorname{Pr}>|F|$ & S. Q. & $\operatorname{Pr}>|F|$ & S. Q. & $\operatorname{Pr}>|F|$ & S. Q. & $\operatorname{Pr}>|F|$ & S. Q. & $\operatorname{Pr}>|F|$ & S. Q. & $\operatorname{Pr}>|F|$ \\
\hline Solo & 1 & 25,24 & 0,0001 & 10,96 & 0,0123 & 0,905 & 0,0001 & 0,104 & 0,0170 & 0,328 & 0,0051 & 11,92 & 0,0001 \\
\hline Biossólido & 3 & 173,9 & 0,0001 & 486,1 & 0,0001 & 67,58 & 0,0001 & 3,952 & 0,0001 & 6,673 & 0,0001 & 801,1 & 0,0001 \\
\hline Solo*Biossólido & 3 & 6,029 & 0,0001 & 1,356 & 0,8051 & 0,205 & 0,0003 & 0,324 & 0,0025 & 1,949 & 0,0001 & 78,54 & 0,0001 \\
\hline Resíduo & 16 & 0,980 & - & 22,04 & - & 0,098 & - & 0,234 & - & 0,500 & - & 5,854 & - \\
\hline Total & 23 & 206,1 & - & 520,5 & - & 68,78 & - & 4,614 & - & 9,420 & - & 897,2 & - \\
\hline
\end{tabular}


Anexo 2. Coeficientes de correlação entre as variáveis do PVAd, no ensaio com adição de $\mathrm{NiCl}_{2}$, calcário e turfa.

\begin{tabular}{|c|c|c|c|c|c|c|c|c|c|c|c|c|}
\hline & & & & $\mathrm{C}$ & $\mathrm{Ni}$ & & $\mathrm{Ni}$ & $\mathrm{Ni}$ & $\mathrm{Ni}$ & $\mathrm{Ni}$ & $\mathrm{Ni}$ & $\mathrm{Ni}$ \\
\hline & M.U. & $\mathrm{N}^{2} \mathrm{Cl}_{2}$ & Calcario & orgânico & total & $\mathrm{pH}$ & trocáve & rgânico & óxid os & solúvel & livre & planta \\
\hline M.O. & 1,00 & & & & & & & & & & & \\
\hline $\mathrm{NiCl}_{2}$ & 0,00 & 1,00 & & & & & & & & & & \\
\hline Calcário & 0,00 & 0,00 & 1,00 & & & & & & & & & \\
\hline$C$ orgânico & 1,00 & 0,00 & 0,00 & 1,00 & & & & & & & & \\
\hline $\mathrm{Ni}$ total & $-0,01$ & 0,99 & $-0,05$ & $-0,02$ & 1,00 & & & & & & & \\
\hline $\mathrm{pH}$ & $-0,39$ & $-0,04$ & 0,88 & $-0,39$ & $-0,08$ & 1,00 & & & & & & \\
\hline Ni-trocável & 0,24 & 0,55 & $-0,69$ & 0,23 & 0,58 & $-0,75$ & 1,00 & & & & & \\
\hline Ni-orgânico & $-0,48$ & 0,57 & 0,51 & $-0,48$ & 0,55 & 0,66 & $-0,28$ & 1,00 & & & & \\
\hline Ni-óxidos & $-0,29$ & 0,80 & 0,44 & $-0,29$ & 0,77 & 0,48 & 0,00 & 0,86 & 1,00 & & & \\
\hline Ni-solúvel & $-0,38$ & 0,36 & $-0,61$ & $-0,39$ & 0,39 & $-0,51$ & 0,66 & $-0,12$ & 0,09 & 1,00 & & \\
\hline Ni-livre & $-0,40$ & 0,29 & $-0,59$ & $-0,40$ & 0,33 & $-0,48$ & 0,60 & $-0,15$ & 0,05 & 0,99 & 1,00 & \\
\hline Ni-planta & $-0,41$ & 0,28 & $-0,54$ & $-0,41$ & 0,31 & $-0,44$ & 0,55 & $-0,13$ & 0,07 & 0,98 & 0,98 & 1,00 \\
\hline
\end{tabular}

Anexo 3. Coeficientes de correlação entre as variáveis do NVdl, no ensaio com adição de $\mathrm{NiCh}$, calcário e turfa.

\begin{tabular}{|c|c|c|c|c|c|c|c|c|c|c|c|c|}
\hline & M.O. & $\mathrm{NiCl}_{2}$ & Calcário & $\begin{array}{c}\text { C } \\
\text { orgânico }\end{array}$ & $\begin{array}{c}\mathrm{Ni} \\
\text { total }\end{array}$ & $\mathrm{pH}$ & $\begin{array}{c}\mathrm{Ni} \\
\text { trocável }\end{array}$ & $\begin{array}{c}\mathrm{Ni} \\
\text { rgânico }\end{array}$ & $\begin{array}{c}\mathrm{Ni} \\
\text { óxid os }\end{array}$ & $\begin{array}{c}\mathrm{Ni} \\
\text { solúvel }\end{array}$ & $\begin{array}{c}\mathrm{Ni} \\
\text { livre }\end{array}$ & $\begin{array}{c}\mathrm{Ni} \\
\text { planta }\end{array}$ \\
\hline M.O. & 1,00 & & & & & & & & & & & \\
\hline $\mathrm{NiCl}_{2}$ & 0,00 & 1,00 & & & & & & & & & & \\
\hline Calcário & 0,00 & 0,00 & 1,00 & & & & & & & & & \\
\hline$C$ orgânico & 1,00 & 0,00 & $-0,01$ & 1,00 & & & & & & & & \\
\hline Ni total & 0,06 & 0,98 & $-0,02$ & 0,06 & 1,00 & & & & & & & \\
\hline $\mathrm{pH}$ & $-0,44$ & $-0,04$ & 0,87 & $-0,45$ & $-0,09$ & 1,00 & & & & & & \\
\hline Ni-trocável & 0,19 & 0,30 & $-0,83$ & 0,20 & 0,33 & $-0,85$ & 1,00 & & & & & \\
\hline Ni-orgânico & $-0,08$ & 0,94 & 0,23 & $-0,08$ & 0,91 & 0,19 & 0,01 & 1,00 & & & & \\
\hline Ni-óxidos & $-0,31$ & 0,55 & 0,64 & $-0,30$ & 0,52 & 0,71 & $-0,47$ & 0,68 & 1,00 & & & \\
\hline Ni-solúvel & 0,20 & 0,56 & $-0,58$ & 0,21 & 0,56 & $-0,62$ & 0,87 & 0,32 & $-0,18$ & 1,00 & & \\
\hline Ni-livre & 0,12 & 0,50 & $-0,58$ & 0,12 & 0,50 & $-0,59$ & 0,88 & 0,26 & $-0,19$ & 0,98 & 1,00 & \\
\hline Ni-planta & $-0,07$ & 0,46 & $-0,64$ & $-0,06$ & 0,45 & $-0,63$ & 0,86 & 0,24 & $-0,26$ & 0,84 & 0,88 & 1,00 \\
\hline
\end{tabular}


Anexo 4. Coeficientes de correlação entre as variáveis do PVAd, ensaio com adição de biossólidos

\begin{tabular}{|c|c|c|c|c|c|c|c|c|c|c|c|c|}
\hline & & & & $\mathrm{C}$ & $\mathrm{Ni}$ & & $\mathrm{Ni}$ & $\mathrm{Ni}$ & $\mathrm{Ni}$ & $\mathrm{Ni}$ & $\mathrm{Ni}$ & $\mathrm{Ni}$ \\
\hline & M.U. & $\mathrm{N}^{\prime C l} l_{2}$ & Calc ario & orgânico & total & $\mathrm{pH}$ & trocável & rgânico & óxid os & solúvel & livre & planta \\
\hline M.O. & 1,00 & & & & & & & & & & & \\
\hline $\mathrm{NiCl}_{2}$ & $-0,61$ & 1,00 & & & & & & & & & & \\
\hline Calcário & $-0,99$ & 0,72 & 1,00 & & & & & & & & & \\
\hline C orgânico & 0,94 & $-0,84$ & $-0,98$ & 1,00 & & & & & & & & \\
\hline Ni total & $-0,49$ & 0,97 & 0,60 & $-0,73$ & 1,00 & & & & & & & \\
\hline $\mathrm{pH}$ & $-0,88$ & 0,92 & 0,94 & $-0,98$ & 0,83 & 1,00 & & & & & & \\
\hline Ni-trocável & 0,79 & $-0,89$ & $-0,85$ & 0,90 & $-0,84$ & $-0,95$ & 1,00 & & & & & \\
\hline Ni-orgânico & 0,43 & $-0,21$ & $-0,44$ & 0,42 & $-0,08$ & $-0,30$ & 0,00 & 1,00 & & & & \\
\hline Ni-óxidos & $-0,63$ & 1,00 & 0,74 & $-0,85$ & 0,97 & 0,92 & $-0,89$ & $-0,23$ & 1,00 & & & \\
\hline Ni-solúvel & 0,62 & $-0,69$ & $-0,65$ & 0,68 & $-0,67$ & $-0,76$ & 0,90 & $-0,32$ & $-0,68$ & 1,00 & & \\
\hline Ni-livre & $-0,30$ & $-0,16$ & 0,26 & $-0,18$ & $-0,30$ & 0,02 & 0,25 & $-0,82$ & $-0,13$ & 0,52 & 1,00 & \\
\hline Ni-planta & 0,64 & $-0,80$ & $-0,69$ & 0,74 & $-0,79$ & $-0,83$ & 0,96 & $-0,26$ & $-0,79$ & 0,48 & 0,95 & 1,00 \\
\hline
\end{tabular}

Anexo 5. Coeficientes de correlação entre as variáveis do NVdl, ensaio com adição de biossólidos

\begin{tabular}{|c|c|c|c|c|c|c|c|c|c|c|c|c|}
\hline & M.O. & $\mathrm{NiCl}_{2}$ & Calcário & $\begin{array}{c}\text { C } \\
\text { orgânico }\end{array}$ & $\begin{array}{c}\mathrm{Ni} \\
\text { total }\end{array}$ & $\mathrm{pH}$ & $\begin{array}{c}\mathrm{Ni} \\
\text { trocável }\end{array}$ & $\begin{array}{c}\mathrm{Ni} \\
\text { orgânico }\end{array}$ & $\begin{array}{c}\mathrm{Ni} \\
\text { óxidos }\end{array}$ & $\begin{array}{c}\mathrm{Ni} \\
\text { solúvel }\end{array}$ & $\begin{array}{c}\mathrm{Ni} \\
\text { livre }\end{array}$ & $\begin{array}{c}\mathrm{Ni} \\
\text { planta }\end{array}$ \\
\hline M.O. & 1,00 & & & & & & & & & & & \\
\hline $\mathrm{NiCl}_{2}$ & $-0,68$ & 1,00 & & & & & & & & & & \\
\hline Calcário & $-0,94$ & 0,72 & 1,00 & & & & & & & & & \\
\hline$C$ orgânico & 0,91 & $-0,75$ & $-0,99$ & 1,00 & & & & & & & & \\
\hline Ni total & $-0,60$ & 0,96 & 0,60 & $-0,64$ & 1,00 & & & & & & & \\
\hline $\mathrm{pH}$ & $-0,90$ & 0,92 & 0,93 & $-0,93$ & 0,85 & 1,00 & & & & & & \\
\hline Ni-trocável & 0,73 & $-0,89$ & $-0,84$ & 0,86 & $-0,82$ & $-0,91$ & 1,00 & & & & & \\
\hline Ni-orgân ico & 0,29 & $-0,12$ & $-0,56$ & 0,58 & 0,04 & $-0,29$ & 0,44 & 1,00 & & & & \\
\hline Ni-óxidos & $-0,83$ & 0,95 & 0,89 & $-0,90$ & 0,88 & 0,98 & $-0,94$ & $-0,31$ & 1,00 & & & \\
\hline Ni-solúvel & 0,84 & $-0,93$ & $-0,89$ & 0,89 & $-0,87$ & $-0,98$ & 0,90 & 0,32 & $-0,97$ & 1,00 & & \\
\hline Ni-livre & 0,81 & $-0,95$ & $-0,82$ & 0,82 & $-0,92$ & $-0,96$ & 0,86 & 0,16 & $-0,95$ & 0,98 & 1,00 & \\
\hline Ni-planta & 0,92 & $-0,84$ & $-0,83$ & 0,80 & $-0,81$ & $-0,94$ & 0,77 & 0,03 & $-0,89$ & 0,91 & 0,90 & 1,00 \\
\hline
\end{tabular}


Anexo 6. Valores dos parâmetros estimados para a regressão múltipla, ajustada às frações do Ni na fase sólida e na solução no

PVAd tratado com biossólidos, e suas respectivas probabilidades de significância.

\begin{tabular}{|c|c|c|c|c|c|c|c|c|c|c|c|c|}
\hline \multirow{2}{*}{$\begin{array}{l}\text { Parâmetros } \\
\text { estimados }\end{array}$} & \multicolumn{2}{|c|}{ Ni Trocável } & \multicolumn{2}{|c|}{ Ni na Mat. orgânica } & \multicolumn{2}{|c|}{ Ni nos óxidos } & \multicolumn{2}{|c|}{ Ni solúvel } & \multicolumn{2}{|c|}{ Ni livre } & \multicolumn{2}{|c|}{ Ni nas plantas } \\
\hline & valor & Prob $>|\mathrm{T}|$ & valor & Prob $>|\mathrm{T}|$ & valor & Prob $>|T|$ & valor & Prob $>|T|$ & valor & Prob $>|\mathrm{T}|$ & valor & Prob $>|\mathrm{T}|$ \\
\hline$a$ & $-1,31$ & 0,9612 & 154,98 & 0,3297 & $-262,64$ & 0,2292 & $-11,60$ & 0,1283 & $-3,69$ & 0,6677 & $-69,47$ & 0,6776 \\
\hline$b$ & 0,73 & 0,6508 & $-11,56$ & 0,2344 & 16,44 & 0,2079 & 0,93 & 0,0611 & 0,42 & 0,4245 & 7,43 & 0,4638 \\
\hline$c$ & 0,44 & 0,8640 & $-14,89$ & 0,3228 & 33,62 & 0,1217 & 1,28 & 0,0895 & 0,44 & 0,5940 & 7,77 & 0,6245 \\
\hline$d$ & 1,52 & 0,6704 & $-24,99$ & 0,2452 & 37,21 & 0,2011 & 2,24 & 0,0482 & 0,98 & 0,4029 & 17,54 & 0,4382 \\
\hline$e$ & $-0,06$ & 0,6745 & 1,04 & 0,2476 & $-2,18$ & 0,0982 & $-0,09$ & 0,0540 & $-0,04$ & 0,4383 & $-0,65$ & 0,4867 \\
\hline$f$ & $-0,21$ & 0,3605 & 1,97 & 0,1531 & $-2,34$ & 0,1897 & $-0,18$ & 0,0213 & 0,10 & 0,2016 & $-1,67$ & 0,2510 \\
\hline$h$ & 0,02 & 0,4371 & $-0,157$ & 0,1892 & 0,30 & 0,0860 & 0,015 & 0,0245 & $-0,01$ & 0,2511 & 0,13 & 0,3042 \\
\hline $\mathrm{R}^{2}$ & 0,9871 & - & 0,8963 & - & 0,9978 & - & 0,9681 & - & 0,9480 & - & 0,9473 & - \\
\hline
\end{tabular}


Anexo 7. Valores dos parâmetros estimados para a regressão múltipla, ajustada às frações do Ni na fase sólida e na solução no NVdl tratado com biossólidos, e suas respectivas probabilidades de significância.

\begin{tabular}{|c|c|c|c|c|c|c|c|c|c|c|c|c|}
\hline \multirow{2}{*}{$\begin{array}{l}\text { Parâmetros } \\
\text { estimados }\end{array}$} & \multicolumn{2}{|c|}{ Ni Trocável } & \multicolumn{2}{|c|}{ Ni na Mat. Orgânica } & \multicolumn{2}{|c|}{ Ni nos Óxidos } & \multicolumn{2}{|c|}{ Ni solúvel } & \multicolumn{2}{|c|}{ Ni livre } & \multicolumn{2}{|c|}{ Ni nas plantas } \\
\hline & valor & Prob $>|\mathrm{T}|$ & valor & valor & Prob $>|\mathrm{T}|$ & valor & valor & Prob $>|\mathrm{T}|$ & valor & valor & Prob $>|\mathrm{T}|$ & valor \\
\hline$a$ & 43,82 & 0,6299 & 79,06 & 0,1148 & $-360,39$ & 0,0987 & 2,46 & 0,6785 & 4,60 & 0,4577 & 37,32 & 0,7966 \\
\hline$b$ & $-2,59$ & 0,6558 & $-4,62$ & 0,1002 & 21,14 & 0,0849 & $-0,11$ & 0,7299 & $-0,25$ & 0,4618 & $-0,69$ & 0,9311 \\
\hline$c$ & $-3,03$ & 0,7299 & $-6,36$ & 0,1717 & 30,90 & 0,1319 & $-0,22$ & 0,6988 & $-0,34$ & 0,5685 & $-4,05$ & 0,9740 \\
\hline$d$ & $-8,84$ & 0,4903 & $-13,69$ & 0,0658 & 62,33 & 0,0553 & $-0,30$ & 0,7176 & $-0,75$ & 0,3855 & 0,11 & 0,9954 \\
\hline$e$ & 0,17 & 0,7149 & 0,36 & 0,1537 & $-1,80$ & 0,1118 & 0,01 & 0,7174 & 0,02 & 0,5622 & 0,15 & 0,8470 \\
\hline$f$ & 0,56 & 0,4417 & 0,85 & 0,0498 & $-3,71$ & 0,0473 & 0,01 & 0,7610 & 0,04 & 0,3731 & $-0,25$ & 0,8244 \\
\hline$g$ & 0,58 & 0,6171 & 1,02 & 0,1116 & $-4,90$ & 0,0846 & 0,03 & 0,7141 & 0,05 & 0,4987 & 022 & 0,9051 \\
\hline$h$ & $-0,04$ & 0,5759 & $-0,06$ & 0,0914 & 0,29 & 0,0659 & 0,001 & 0,7330 & $-0,003$ & 0,4760 & 0,002 & 0,9835 \\
\hline $\mathrm{R}^{2}$ & 0,9254 & - & 0,9547 & - & 0,9967 & - & 0,9734 & - & 0,9799 & - & 0,9772 & - \\
\hline
\end{tabular}




\section{REFERÊNCIAS BIBLIOGRÁFICAS}

ADRIANO, D.C. Trace elements in the terrestrial environment. New York: Springer-Verlag, 1986.533p.

AHNSTROM, Z.S.; PARKER, D.R. Development and assessment of a sequential extraction procedure for fractionation of soil cadmium. Soil Science Society of America Journal, v.63, p.1650-1658, 1999.

ALLISON, J.D.; BROWN, D.S.; NOVO-GRADAC, KJ. MINTEQA2/PRODEFA: a geochemical assessment model for environmental systems. Version 3.0 user's manual. Athens: U.S. Environmental Protection Agency, 1991. 107p. (EPA/600/391/021)

ALLOWAY, B.J. The origins of heavy metal in soils. In: ALLOWAY, B.J. Heavy metal in soils. New York: John Wiley, 1990. p. 19-38.

AMARAL SOBRINHO, N.M.B. Interações dos metais pesados siderúrgicos com solo Podzólico Vermelho Amarelo. Viçosa, 1993. 163p. Tese (Doutorado) Universidade Federal de Viçosa.

AMARAL SOBRINHO, N.M.B.; VELOSO, A.C.X.; COSTA, L.M.; OLIVEIRA, C. Solubilidade de metais pesados em solo tratado com resíduo siderúrgico. Revista Brasileira de Ciência do Solo, v.21, p.9-16, 1997. 
ANDREOLI, C.V.; PEGORINI, E.S. Gestão de biossólidos: Situação e perspectiva. In: SEMINÁRIO SOBRE GERENCIAMENTO DE BIOSSÓLDOS DO MERCOSUL, 1., Curitiba, 1998. Palestras. Curitiba: SENEPAR/ABES, 1998. p.11-18.

ANJOS, A.R.M. Lixiviação de espécies químicas em latossolos sucessivamente tratados com biossólidos e disponibilidade de metais pesados para plantas de milho. Piracicaba, 1999. 191p. Tese (Doutorado) - Escola Superior de Agricultura "Luiz de Queiroz", Universidade de São Paulo.

ASSOCIAÇÃO BRASILEIRA DE NORMAS TÉCNICAS. NBR 10.004: resíduos sólidos. Rio de Janeiro, 1987. 63 p.

BABCOCK, K.L. Theory of chemical properties of soil colloidal systems at equilibrium. Hilgardia, v.34, n.11, p.417-542, 1963.

BARRETO, M.C.V. Degradação da fração orgânica de diferentes resíduos e efeito em algumas propriedades químicas e físicas de dois solos. Piracicaba, 1995. 106p. Tese (Doutorado) - Escola Superior de Agricultura "Luiz de Queiroz", Universidade de São Paulo.

BASTA, N.T.; SLOAM, J.J. Bioavaibility of heavy metal in strongly acidic soils treated with exceptional quality biosolids. Journal of Environmental Quality, v.28, p.633-638, 1999.

BAXTER, J.C.; AGUILAR, M.; BROWN, K. Heavy metal and persistent organics at a sewage sludge disposal site. Journal of Environmental Quality, v.12, p.311-316, 1983.

BECKETT, P.H . The use of extractants in studies on trace metals in soil, sewage sludges, and sludge-treated soil. Advances in Soil Science, v.9, p. 143-176, 1989. 
BERTI, W.R.; JACOBS, L.W. Chemistry and phitotoxicity of trace elements from repeated sewage sludge application. Journal of Environmental Quality, v.25, n.5, p.1025-1032, 1996.

BERTONCINI, E.I. Mobilidade de metais pesados em solos tratados com lodo de esgoto. Piracicaba, 1997. 90p. Dissertação (Mestrado) - Escola Superior de Agricultura "Luiz de Queiroz”, Universidade de São Paulo.

BERTONCINI, E.I. Comportamento de $\mathrm{Cd}, \mathrm{Cr}, \mathrm{Cu}, \mathrm{Ni}$, e $\mathrm{Zn}$ em Latossolos sucessivamente tratados com biossólidos: Extração sequencial, Fitodisponibilidade e caracterização de substâncias húmicas. Piracicaba, 2002. 195p. Tese (Doutorado)Escola Superior de Agricultura “Luiz de Queiroz”, Universidade de São Paulo.

BETTIOL, W.; CARVALHO, P.C.T. Lodo de esgoto como fertilizante para a cultura do milho (Zea mays L.) híbrido HMDO 7974. Fertilizantes, v.4, n.1, p. 9-11, 1982.

BINGHAM, F.T.; STRONG, J.E.; SPOSITO, G. Influence of chloride salinity on cadmium uptake by Swiss chard. Soil Science, v. 135, p. 160-165, 1983.

BINGHAM, F.T.; SPOSITO, G.; STRONG, J.E. The influence of chloride on the availability of cadmium. Journal of Environmental Quality, v.13, p.71-74, 1984.

BOARETO, A.E.; MURUAKA, T.; NAKAGAWA, J.; CHITOLINA J.C. Níquel e cádmio em grãos de feijão produzidos em solo adubado com lodo de esgoto. In: REUNIÃO BRASILEIRA DE FERTILLIDADE DO SOLO E NUTRIÇÃO DE PLANTAS, 20., Piracicaba, 1992. Adubação, produtividade, ecologia: anais. Piracicaba: SBCS, 1992. p.400-401.

BRÜMMER, G.W., GERTH, J.; TILLER, K.G. Reaction kinetics of the adsorption and desorption of nickel, zinc, and cadmium by goethite. I. Adsorption and diffusion of metals. Journal of Soil Science, v. 39 p.37-52, 1988. 
BUCHTER, B.; DAVIDOFF, B; AMANCHER, M.C.; HINZ, C.; ISKANDAR, I.K.; SELIM, H.M Correlation of freundlich $K d$ and $n$ retention parameters with soils and elements. Soil Science, v.148, p.370-379, 1989.

CAMARGO, O.A.; MONIZ, A.C.; JORGE, J.A.; VALADARES, J.M. Métodos de análise química, mineralógica e física de solos. Campinas: IAC, 1986. 94p.

CAMOBRECO, V.J.; RICHARDS, B.K.; STEENHUIS, T.S.; PEVERLY, J.H.;

McBRIDE, M.B. Movement of heavy metals through undisturbed and homogenized soil columns. Soil Science, v.161, p.740-750, 1996.

CAÑADAS, R.C.; SANCHIDRIAN, J.R; RIVERO, V.C. Distribución de Pb, Cd, Cu y $\mathrm{Cr}$ entre distintas fases sólidas en algunos tipos de suelos. Anales de Edafología y Agrobiologia, v.45, p.613-630, 1986.

CANDELARIA, L.M.; CHANG, A.C. Cadmium activities, solution speciation, and solid phase distribution of $\mathrm{Cd}$ in cadmium nitrate in sewage sludge-treated soil systems. Soil Science, v.162, n.10, p.722-732, 1997.

CARVALHO, P.C.T.; BARRAL, M.F. Aplicação de lodo de esgoto como fertilizante. Fertilizantes, v.3, n.2, p. 1-4, 1981.

CHANG, A.C.; PAGE, A.L.; WARNEKE, J.E.; GRGUREVIC E. Sequential extraction on soil heavy metals following a sludge application. Journal of Environmental Quality, v.13, n.1, p.33-38, 1984a.

CHANG, A.C.; WARNEKE, J.E.; PAGE, A.L.; LUND, L.J. Accumulation of heavy metals in sewage sludge-treated soils. Journal of Environmental Quality, v.13, n.1, p.87-91, 1984b.

CHAO, T.T. Use of partial dissolution techniques in geochemical exploration. Journal of Geochemical Exploration. v.20, p.101-135, 1988. 
CHRISTENSEN, T.H.; LEHMANN, N.; JACKSON, T.; HOLM, P.E. Cadmium and nickel distribution coefficients for sandy aquifer materials. Journal of

Contaminant Hydrology, v.24, p.75-84, 1996.

COFFIN, D.E. A method for the determination of free iron in soil and clays. Canadian Journal of Soil Science, v.43, p.7-17, 1963.

COX, J.A.; BRAJTER, K. Separation of mixtures of cations by Donnan dialysis. Analytical Chemistry, v. 53, p.1308-1309, 1981.

COX, J.A.; CHENG, K.H. Enrichment of anions of weak acids by Donnan dialysis. Analytical Chemistry, v.50, n.4, p. 601-602, 1978.

CRAVO, M.S. Composto de lixo urbano como fonte de nutriente e metais pesados para alface. Piracicaba, 1995. 148p. Dissertação (Mestrado) - Cento de Energia Nuclear na Agricultura, Universidade de São Paulo.

CRIPPS, R.W.; MATOCHA, J.E. Effects of sewage application to ameliorate iron deficiency of grain sorghum. Communications in Soil Science and Plant Analysis, v.22, p.1931-1940, 1991.

CRIPPS, R.W.; WINFREE, S.K.; REAGAN, J.L. Effects of sewage sludge application method on corn production. Communications in Soil Science and Plant Analysis, v.23, n.15, p.1705-1715, 1992.

DORDAS, C.; SAH, R.; BRWN, P.H.; ZENG, Q.; HU, H. Remobilização de micronutrientes e elementos tóxicos em plantas superiores. In: FERREIRA, M.E.; CRUZ, M.C.P.; RAIJ, B.van; ABREU, C.A. (Ed.). Micronutrientes e elementos tóxicos na agricultura. Jaboticabal: CNPq; FAPESP; POTAFOS, 2001. cap. 3, p.43-69. 
DUNDLEY, L.M.; McNEAL, B.L.; BAHAM, J.E.; CORAY, C.S.; C HENG, H.H. Characterization of soluble organics compounds and complexation of copper, nickel and zinc in extracts of sludge amended soils. Journal of Environmental Quality, v.6, p.341-348, 1987.

EATON, A. D.; CLESCERI L. S.; GREENBERG A. E. Standard Methods for examination of water and wastewater. 19. ed. Washington: APHA; AWWA; WEF, 1995. 953p.

EGREJA FILHO, F.B. Extração sequencial de metais pesados em solos altamente intemperizados: Utilização de componentes-modelo e planejamento com misturas ternárias na otimização do modelo. Viçosa, 2000. 287p. Tese (Doutorado) Universidade Federal de Viçosa.

EICK, M.J.; FENDORF, S.E. Reaction sequence of nickel (II) with kaolinite: mineral dissolution and surface complexation and precipitation. Soil Science Society of America Journal, v.62, p.214-219, 1998.

ELLIOTT, H.A; LIBERATI, M.R; HUANG, C.P. Competitive adsorption of heavy metal by soils. Journal of Environmental Quality, v.15, n.3, p.214-217, 1986.

EMMERICK, W.E.; LUND, L.J.; PAGE, A.L.; CHAG, H.M. Solid phases forms of heavy metals in sewage sludge-treated soils. Journal of Environmental Quality, v.11, p.174-178, 1982.

EMPRESA BRASILEIRA DE PESQUISA AGROPECUÁRIA. Centro Nacional de Solos. Manual de métodos de análises de solos. 2. ed. Rio de Janeiro: 1997. 212p. 
EPSTEIN, E. TAYLOR, J.M.; CHANEY, R.L. Effects of sewage sludge and sludge compost applied to soil on soil physical and chemical properties. Journal of Environmental Quality, v.5, n.4, p.422-426, 1976.

ESSINGTON, M.E.; MATTIGOD, S.V. Trace element solid-phase association in sewage sludge and sludge-amended soil. Soil Science Society of America Journal, v.55, p. 355-356, 1991.

ESTADOS UNIDOS. Environmental Protection Agency 40 CFR Parts 403 and 503. Final Rules: Standards for the use of sewage sludge. v.58, n.32, p. 9248-9415, 1993.

ESTADOS UNIDOS. Environmental Protection Agency. Soil screening guidance: technical background document table on contents. Washington, 1996. (EPA/540/R95/128)

ESTADOS UNIDOS. Environmental Protection Agency. A guide to the biosolids: Risk Assessments for the EPA Part 503. Washington, 1995. 144 p. (EPA/832-B93-005)

FELMY, A.R.; GIRVIN, D.C.; JENNE, E.A. MINTEQ: a computer program for calculating aqueous geochemical equilibria. Atlanta: US Environmental Protection Agency, 1984. (EPA-600/3-84-032)

FITCH, A.; HELMKE, P.A. Donnan equilibrium/ graphite atomic furnace absorption estimates of soil extract complexation capacities. Analytical Chemistry, v.61, p.1295-1298, 1989.

GOMES, P.C. Fracionamento e biodisponibilidade de metais pesados influenciados por calagem e concentração de metais em Latossolo Vermelho amarelo. Viçosa, 1996. 161p. Tese (Doutorado) - Universidade Federal de Viçosa. 
HASHIMOTO, I.; JACKSON, L.M. Rapid dissolution of allophane and kaolinitehalloysite after dehydration. Clays and Clay Minerals, v.7, p.102-113, 1960.

HELMKE, P.A. Chemistry of cadmium in soil solution. In: MCLAUGHLIN, M.J.; SINGH, B.R. (Ed.). Cadmium in soils and plant. Dordrecht: Kluwer Academic Publishers, 1999. cap. 3, p. 39-64.

HELMKE, P.A.; SALAN, A.K.; LI,Y. Measurement and behavior of indigenous levels of the free hidratated cátions of $\mathrm{Cu}, \mathrm{Zn}$ and $\mathrm{Cd}$ in the soil-water system (Compact disc). In: INTERNATIONAL CONFERENCE ON BIOGEO-CHEMISTRY OF TRACE ELEMENTS, 3., Paris, 1997. Proceedings. Paris, 1997.

HICKEY, M.G.; KITTRICK, M.G. Chemical partition of cadmium, copper, nickel and zinc in soils and sediments containing high levels of heavy metals. Journal of Environmental Quality, v. 13, p. 372-376, 1884.

HINESLEY, T.D.; ALEXANDER, D.E.; REDBORG, K.E.; ZIEGIER, E.L. Differential accumulation of cadmium and zinc by hybrids grown on soil amended with sewage sludge. Agronomy Journal, v.74, p. 469-474, 1982.

HOLM, P.E.; CHRISTENSEN, T.H.; TJELL, J.C.; McGRATH, S.P. Speciation of cadmium in polluted soils. Journal of Environmental Quality, v.24, p.183-190, 1995.

HOODA, P.S.; ALLOWAY, B.J. The effect of liming on heavy metal concentrations in weat, carrots and spinach grown on previously sludge applied soils. Journal of Agricultural Science, v.127, p.289-294, 1996.

IYENGAR, S.S.; MARTENS, D.C.; MILLER, W.P. Distribution and plant availability of soil zinc fractions. Soil Science Society of America Journal, v.45, p.735-739, 1981. 
JOHN, M.K. Cadmium uptake by eight food crops as influenced by various soils levels of cadmium. Environmental Pollution. v.4, p.7-15, 1973.

KABATA-PENDIAS, A.; PENDIAS, H. Trace elements in soil and plants, Boca Raton: CRC Press, 1984. 315 p.

KÄMPF, N.; SCHWERTMANN, U. The $5 \mathrm{M} \mathrm{NaOH}$ concentration treatment for iron oxides in soils. Clays and Clay Minerals, v.30, p.401-408, 1982.

KIN, S.D.; ALLEN, H.E.; CHA, D.K. Influence of dissolved organic matter on the toxicity of cupper to Cerodaphania dubia: Effect on complexation kinetics. Environmental Toxicology and Chemistry, v.18, p. 2433-2437, 1999.

KIRKHAM, B.B. Agricultural use of phosphorus in sewage sludge. Advances in Agronomy, v.35, p.129-1163, 1982.

KORCAK, R.F. Effects of applied sewage sludge compost and fluidizedbed material on apple seedling growth. Communications in Soil Science and Plant Analysis, v.11, p.571-585, 1980 .

KUCHENRITHER, R.D.; McMILLAN, S.I. Preview analysis of national sludge survey. BioCycle, v.32, p.60-62, 1990.

KUO, S.P; HEILMAN, P.E.; BAKER, A.S. Distribution and forms of Cu, Zn, Cd, Fe, and Mn in soils near a cupper smelter. Soil Science, v.135, p.101-109, 1983.

LAKE, D.L.; KIRK, P.W.W.; LESTER, J.N. Fractionation, characterization and speciation of heavy metal in sewage sludge and sludge amended soils, a review. Journal of Environmental Quality, v.13, p.175-183, 1984. 
LAMPERT, J.K. Measurement of trace cations activities by Donnan membrane equilibrium and atomic absorption analysis. Wisconsin, 1982. 169p. PhD (Thesis) University of Wisconsin.

LEE, S.Z.; ALLEN, H.E; HUANG, C.P.; SPARKS, P.F.; PEIJNENBURG, W.J.G.M. Predicting soil-water partition coefficients for cadmium. Environmental Science and Technology, v. 30, p. 3418-3424, 1996.

LESLIE, R. Liquid sludge as a farm fertilizer. Compost Science, v.11, p.24-25, 1970.

LI, Z.; SHUMAN, L.M. Redistribution of forms of zinc, cadmium and nickel in soil treated with EDTA. The Science of Total Environment, v.191, p. 95-107, 1996.

LINDSAY, W.L. Chemical equilibrium in soils. New York: John Wiley, 1979. 449p.

LOGAN, T.J; CHANEY, R.L. Utilization of municipal wastewater and sludge on land metals. In: PAGE, A.L. (Ed). Utilization of municipal wastewater and sludge on land. Riverside: University of California, 1983. p.325-336.

LOVELAND, P.J ; BULLOCK, P. Chemical and mineralogical proprieties of known podzolic soils in comparison with soil of other groups. Journal of Soil Science, v.32, p.523-540, 1976.

LUDUVICE, M. Gestão de biossólidos e o mercosul. In: SEMINÁRIO SOBRE GERENCIAMENTO DE BIOSSÓLDOS DO MERCOSUL. 1., Curitiba, 1998. Palestras. Curitiba: SENEPAR/ABES, 1998. p.9-10.

LUND, L.J.; PAGE, A.L.; SPOSITO, G. Determination and prediction of chemical forms of trace metals in sewage sludges and sludge-amended soils. Ohio: US Environmental Protection Agency, 1980. (Final Technical Report, Grant n ${ }^{\circ}$. R84516010) 
MA, Q.Y.; LINDSAY, W.L. Estimation of $\mathrm{Cd}^{2+}$ and $\mathrm{Ni}^{2+}$ activities in soils by chelation. Geoderma, v.68, p.123-133, 1995.

MANCEAU, A.; CALAS, G. Nickel-bearing clay minerals: II. Intracrystalline distribution of nickel: An X-ray absorption study. Clays and Clays Minerals, v.21 p.341-360, 1986.

MANN, S.S.; RITCHIE, G.S.P. The influence of $\mathrm{pH}$ on the form of cadmium in four west Australian soils. Australian Journal of soil Research, v.31, p.255-270, 1993.

MATTIAZZO-PREZOTTO, M. E. Comportamento de cobre, cádmio, crômio, níquel e zinco adicionados a solos de clima tropical em diferentes valores de $\mathrm{pH}$. Piracicaba, 1994. 197p. Tese (Livre Docência) - Escola Superior de Agricultura “Luiz de Queiroz", Universidade de São Paulo.

MATTIGOD, S.V. AND PAGE, A.L. Assessment of metal pollution in soils. In: THORNTON, I. (Ed.). Applied environmental geochemistry, New York: Academic Press, 1983. p.355-391. (Academic Press Geology Series)

MAYS, D.A.; TERMAN, G.L.; DUGAN, J.C. Municipal compost: effects on crops yield and soil properties. Journal of Environmental Quality, v.2, n.1, p.89-92, 1973.

McBRIDE, M.B. toxic metal accumulation from agriculture use of sludge: are USEPA regulations protective? Journal of Environmental Quality, v.24, n.1, p.5-18, 1995.

McBRIDE, M.B.; RICHARDS, B.K; STEENHUIS, T.; RUSSO, J.J.; SAUVÉ, S. Mobility and solubility of toxic metal and nutrients in soil fifteen year after hardwood forest. Soil Science, v.162, n.7, p.487-500, 1997. 
MCDUFF, R.E.; MOREL, P.M. Description and use of the chemical equilibrium program REDEQL, I Keck Lab. Pasadena: California Institute of Technology, 1973. 75p. (Tech. Reporter EQ-73-02)

McGRATH, S.P. Chromium and nickel. In: ALLOWAY, B.J. (Ed.). Heavy metals in soils. London: Blackwell Academic, 1995. p.152-178.

McGRATH, S.P.; CEGARRA, J. Chemical extractability of heavy metals during and after long-term application of sewage sludge. Journal of Soil Science. v.43, p.313$321,1992$.

McKEAGUE, J.A.; DAY, J.H. Dithionite- and oxalate-extractable $\mathrm{Fe}$ and $\mathrm{Al}$ as aids in differentiating various classes of soils. Canadian Journal of Soil Science, v.46, p.13-22, 1966.

MILLER W.P.; MARTENS, D.C; ZELAZNY, L.W. Effect of sequence in extraction of heavy metal from soils. Soil Science Society of America Journal, v.50, p.598-601, 1986.

MOREL, F.; MORGAN, J.J. A numerical method for computing equilibria in aqueous solutions. Environmental Science Technology, v. 6, p. 58-67, 1972.

OLIVEIRA, F.C. Metais pesados e formas nitrogenadas em solos tratados com lodo de esgoto. Piracicaba, 1995. 90p. Dissertação (Mestrado) - Escola Superior de Agricultura "Luiz de Queiroz", Universidade de São Paulo.

OLIVEIRA, F.C. Disposição de lodo de esgoto e composto de lixo urbano num latossolo vermelho amarelo cultivado com cana-de-açúcar. Piracicaba, 2000. 247p. Tese (Doutorado) - Escola Superior de Agricultura “Luiz de Queiroz”, Universidade de São Paulo. 
PEARSON, R.G. Hard and soft acids and bases. Journal of America Chemistry Society, v.85, p.3533-3539, 1963.

PIERRISNARD, F. Intact de I' amendment dês boues residuaires de la ville de Marseille sur de sols a vocatio acgicole : comportment du $\mathrm{Cd}, \mathrm{Cr}, \mathrm{Cu}, \mathrm{Ni}, \mathrm{Pb}, \mathrm{e} \mathrm{Zn}$ des hidrocarures et des composes polares. Marseille, 1996. 408p. These (Docteur Géosciences de I' Emvironnement) - Université de Droit d' Ecomomie et dês Science d' AIX-MARSEILLE.

PORTA, A.A.; RONCO, A.E. $\mathrm{Cu}$ (II) acute toxicity to the rotifer Brachionus calciflorus, as affected by fulvic acids of fresh water origin. Environmental Pollution, v.82, p.263-267, 1993.

RAIJ, B. van; QUAGGIO, J.A. Métodos de análise de solos para fins de fertilidade. Campinas: Instituto Agronômico, 1983. 31p. (Boletim Técnico, 81).

RAIJ, B. van; CANTARELlA, H.; QUAGGIO, J.A.; FURLANI, A.M.C. Recomendações de adubação e calagem para o Estado de São Paulo. Campinas: IAC, 1986. 285p.

REIS, T.C. Variação da acidez do solo em resposta a adição de materiais orgânicos. Piracicaba, 1998. 65p. Dissertação (Mestrado) - Escola Superior de Agricultura “Luiz de Queiroz”, Universidade de São Paulo.

REIS, T.C.; RODELLA, A.A. Cinética de degradação da matéria orgânica e variação do $\mathrm{pH}$ do solo sob diferentes temperaturas. Revista Brasileira de Ciência do Solo, v.26, n.3, p. 619-626, 2002.

RHOADES, J.D. Electrical conductivity methods for measuring and mapping soil salinity. Advances in Agronomy. v.49, p.201-251, 1993. 
ROSS, S. M. Toxic metals is soil-plant-systems . Chichester: John Wiley, 1994. 469p.

SABEY, B.R.; AGBIN, N.N.; MARKSTROM, D.C. Land application of sewage sludge. Journal of Environmental Quality, v.6, n.1, p.52-58, 1977.

SALAN, A.K.; HELMKE, P.A. The pH dependence of free ionic activities and total dissolved concentrations of copper and cadmium in soil solutions. Geoderma, v.83, p.281-291, 1998.

SANTOS, HF Aplicação de lodo de estação de tratamento de esgotos em solos agrícolas. Revista D.A.E., v.32, n.122, p.31-40, 1979.

SAS INSTITUTE. SAS/STAT user's guide: version 6.12. Cary, 1996. 1686 p.

SAUERBECK D.R.; HEIN, A. The nickel uptake from different soils and its prediction by chemical extractions. Water, Air and Soil Pollution, v.57/58, p. 861-871, 1991.

SAUVÉ, S. HENDERS, T, W. ALLEN, H.E. Solid-solution proportion of metals in contamined soils: dependence on $\mathrm{pH}$, total metal burden, and organic matter. Environmental Science \& Tecnology, v.34, n.7, p.1125-1131, 2000.

SCHWERTMANN, U.; CAMBIER, P.; MURAD, E. Properties of goethites of varying cristallinity. Clays and Clay Minerals, v.33, p.369-378, 1985.

SENESI, N; SPOSITO, G.; HOLTZCLAW, K.M.; BRADFORD, G.R. Chemical properties of metal-humic fractions of a sewage sludge-amended Aridisol. Journal of Environmental Quality, v. 18, p.186-194, 1989.

SHUMAN, L. M. Adsorption of Zn by Fe and Al hydrous and oxides as influenced by aging and pH. Soil Science Society of America Journal, v.41, p.703-706, 1977. 
SHUMAN, L. M. Zinc, Manganese and Copper in soil fractions. Soil Science, v.127, p.10-17, 1979.

SHUMAN, L.M. Separating soil iron-and manganese-oxide fractions for microelements analysis. Soil Science Society of America Journal, v. 46, p.1099-1102, 1982.

SHUMAN, L. M. Fractionation method for soil microelements. Soil Science, v.140, p.11-12, 1985.

SHUMAN, L.M. Chemical forms of micronutrients in soils. In: MORTVEDT, J.J. (Ed.). Micronutrients in agriculture. 2. ed. Madison: Soil Science Society of America, 1991. cap.5. p.113-144. (Book Series, 4).

SILVA, F.C. Uso agronômico de lodo de esgoto: efeitos em fertilidade do solo e qualidade da cana-de-açúcar. Piracicaba, 1995. 165p. Tese (Doutorado) - Escola Superior de Agricultura “Luiz de Queiroz”, Universidade de São Paulo.

SMOLDERS, E.; BISSANI, C.; HELMKE, P.A. Liming reduces Cadmium uptake from soil; why doesn't it work better? In: INTERNATIONAL CONFERENCE ON BIOGEOCHEMISTRY OF TRACE ELEMENTS: CONTAMINATED SOILS, 5, Vienna, 1999. Proceedings. Vienna: International Society for Trace Elements, 1999. p.528-529.

SOMMERS, L.E.; NELSON, D.W.; YOST, K.J. Variable nature of chemical composition of sewage sludges. Journal of Environmental Quality, v. 5, n.3, p.303-306, 1976.

SPOSITO, G.; COVES, I SOILCHEM: A computer program for the calculation of chemical speciation in soils. Riverside: The Kearny Foundation of Soil Science, University of California, 1988. 92p. 
SPOSITO, G.; LUND, L.J.; CHANG, A.C. Trace metal chemistry in arid-zone field soil amended with sewage sludge: I. Fractionation of $\mathrm{Ni}, \mathrm{Cu}, \mathrm{Zn}, \mathrm{Cd}$ and $\mathrm{Pb}$ in solid phases. Soil Science Society of America Journal, v.46, p. 260-264, 1982.

SPOSITO, G.; MATTIGOD, S.V. GEOCHEM: a computer program for the calculation of chemical equilibria in soil solutions and other natural water system. Riverside: University of California, Dept. of Soil and Environmental Science, 1980. 92p.

STOVER, R.C.; SOMMERS, L.E.; SILVEIRA, D.J. Evaluation of metals in wastewater sludge. Journal of the Pollution Control Federation, v.48, p.2165-2175, 1976.

TAYLOR, R.W.; XIU, H.; MEHADI, A.A.; SHUFORD, J.W.; TADESSE, W. Fractionation of residual cadmium, copper, nickel, lead and zinc in previously sludge-amended soil. Communications in Soil Science and Plant Analysis, v.26, p.2193-2204, 1995.

TEMMINGHOFF, E.J.M.; PLETTE, A.C.C.; ECK, R. van; RIEMSDIJK, W.H. van. Determination of the chemical speciation of trace metals $n$ aqueous systems by the Wageningen Donnan membrane technique. Analytical Chemical Acta. v.417, p.149-157, 2000.

TESSIER, A.; CAMPBEL, P.G.C.; BISSON, M. Sequential extraction procedure for the speciation of particulate trace metals. Analytical Chemistry, v.51, n.7, p.844-851, 1979.

THEIS, T.L.; RICHTER, R.O.. Chemical speciation of heavy metals in power plant ash pond leachate. Environmental Science and Technology, v.13, p.219-224, 1979. 
UREN, N. Forms, reactions, and availability of $\mathrm{Ni}$ in soils. Advanced in Agronomy, v.48, p. 141-195, 1992.

VARADACHARI, C.; CHATTOPADHYAY, T. Complexation of humic substances with oxides of iron and aluminum. Soil Science, v.162, p.28-34, 1997.

VIETS JUNIOR, F.G. Chemical end availability of heavy metal in soils. Agriculture and Food Chemistry, v.10, p.174-178, 1962.

WANG, P.; QU, E.; LI, Z.; SHUMAN, L.M. Fractions and availability of nickel in loessial soil amended with sewage sludge. Journal of Environmental Quality, v.26, p.795-801, 1997.

WESTALL, J. MICROQL: I. A chemical equilibrium program in BASIC. II. Computation of adsorption equilibrium in BASIC. Dubendorf: Swiss Inst. Tech. EAWAG, 1979. 77p.

WESTALL, J.; ZACHARY, J.L.; MOREL, F.M.M. MINEQL: a computer program for the calculation of chemical equilibrium composition of aqueous systems. Massachusetts: Mass. Inst. Tech. Dept. Civil Eng. Tech., 1976. 91 p. (Note, 18)

WILLIAMS, D.E.; VLAMIS, J.; PUKITE, A.H.; COREY, J.E. Metal movement in sludge-amended soils: a nine-year study. Soil Science, v.143, n.2, p.124-131, 1987.

WU, Q.; HENERSHOT, W.H.; MARSHALL, W.D.; GE, W. Speciation of cadmium, copper, lead and zinc in contaminated soils. Communications in Soil Science Plant Analysis, v. 31, p. 1129-1144, 2000. 